\title{
IUCN
}

\section{State of nature conservation systems in South-Eastern Europe}

Maja Vasilijević, Sanja Pokrajac, Boris Erg

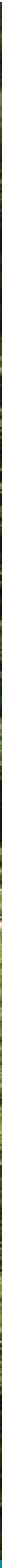

INTERNATIONAL UNION FOR CONSERVATION OF NATURE 

State of nature conservation systems in South-Eastern Europe

Maja Vasilijević, Sanja Pokrajac, Boris Erg 
The designation of geographical entities in this publication and the presentation of the material do not imply the expression of any opinion whatsoever on the part of IUCN or the MAVA Foundation concerning the legal status of any country, territory, or area, or of its authorities, or concerning the delimitation of its frontiers or boundaries.

For the purpose of this publication, the name Macedonia is used to refer to The former Yugoslav Republic of Macedonia. The views expressed in this publication do not necessarily reflect those of IUCN and the MAVA Foundation.

This publication has been made possible by funding from the MAVA Foundation.

Published by:

Copyright:

Citation:

ISBN:

DOI:

Collaborators:

Cover photo:

Designed by:

Printed by:

Available from:
IUCN, Gland, Switzerland and IUCN Regional Office for Eastern Europe and Central Asia (ECARO), Belgrade, Serbia

() 2018 IUCN, International Union for Conservation of Nature and Natural Resources

Reproduction of this publication for educational or other non-commercial purposes is authorised without prior written permission from the copyright holder provided the source is fully acknowledged. Reproduction of this publication for resale or other commercial purposes is prohibited without prior written permission of the copyright holder.

Vasilijević, M., Pokrajac, S., Erg, B. (eds.) (2018). State of nature conservation systems in South-Eastern Europe. Gland, Switzerland and Belgrade, Serbia: IUCN, xii+58pp.

978-2-8317-1939-9 (PDF)

978-2-8317-1940-5 (print version)

https://doi.org/10.2305/IUCN.CH.2018.19.en

Vasil Anastasovski, Milena Bataković, Ferdinand Bego, Taulant Bino, Patricija Gambiroža, Tjaša Đokić, Martina Kačičnik Jančar, Tadej Kogovšek, Goran Krivanek, Srđan Marinčić, Biljana Opačić, Ivana Plavac, Dejan Radošević,

Goran Sekulić, Nataša Stanišić, Gabrijela Šestani, Petra Štrbenac, Sara Todorović, Ramona Topić, Marija Trikić, Marko Tucakov, Azra Velagić, Irina Zupan

Plitvice Lakes National Park, Croatia @ IUCN

Imre Sebestyén Jr. / Unit Graphics Studio

Pannonia Print

IUCN Regional Office for Eastern Europe and Central Asia (ECARO)

Dr Ivana Ribara 91

11070 Belgrade, Serbia

Tel +381112272411

Fax +381112272 531

www.iucn.org./resources/publications 


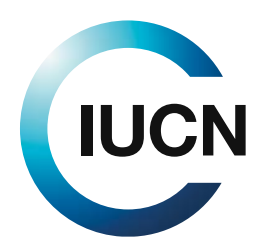

IUCN, International Union for Conservation of Nature IUCN is a membership Union uniquely composed of both government and civil society organisations. It provides public, private and non-governmental organisations with the knowledge and tools that enable human progress, economic development and nature conservation to take place together.

Created in 1948, IUCN is now the world's largest and most diverse environmental network, harnessing the knowledge, resources and reach of more than 1,300 Member organisations and some 10,000 experts. It is a leading provider of conservation data, assessments and analysis. Its broad membership enables IUCN to fill the role of incubator and trusted repository of best practices, tools and international standards.

IUCN provides a neutral space in which diverse stakeholders including governments, NGOs, scientists, businesses, local communities, indigenous peoples organisations and others can work together to forge and implement solutions to environmental challenges and achieve sustainable development.

\section{www.iucn.org https://twitter.com/IUCN/}

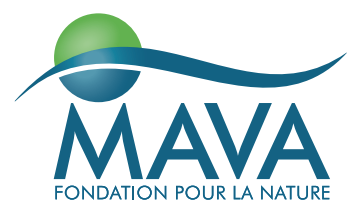

\section{MAVA Foundation}

MAVA was established in 1994 and is a family-led, Swiss-based philanthropic foundation whose mission is to engage in strong partnerships to conserve biodiversity for future generations. Under the leadership of its President, André Hoffmann, the foundation strives to help protect and rebuild the earth's natural wealth, ensure sustainable use of natural resources and build strong conservation communities. MAVA has four different programmes. Three are region-based: the Alpine Arc and Switzerland, the Mediterranean Basin and Coastal West Africa. In each place MAVA has helped build extensive conservation capacity, to create and support conservation institutions and influence policy. The fourth programme, the Sustainable Economy, provides opportunities to affect global trends and have an impact that goes beyond MAVA priority regions. The programme explores how to ensure economic prosperity, within the resources of one planet, addressing the issue of overconsumption of natural resources beyond their capacity to regenerate. MAVA also funds other work that reaches beyond the four programmes through their global portfolio of projects. www.mava-foundation.org

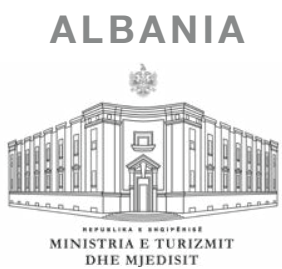

Ministry of Tourism and Environment

The Ministry of Tourism and Environment has the mission to develop and propose policies, strategies and action plans for the protection of environment, forests, waters and fisheries in order to achieve sustainable development, improve the quality of life and enable the country to join the European Union. The Ministry implements relevant national policies, defines priority environmental investments, develops national research programmes in the field of environmental protection and coordinates environment protection-related activities. www.turizmi.gov.al

\section{BOSNIA AND HERZEGOVINA}

\section{Federal Ministry of Environment and Tourism}

The Federal Ministry of Environment and Tourism performs administrative, professional and other tasks falling under competence of the Federation of Bosnia and Herzegovina related to the development of environmental strategies and policies, protection, development of quality standards and monitoring of air, water and soil, ecological monitoring, drafting of tourism strategies and policies, visitor monitoring, and other tasks as specified by law.

\section{www.fmoit.gov.ba}

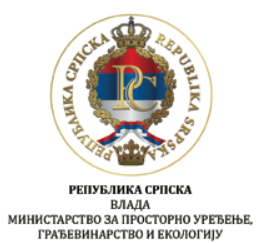

Ministry of Spatial Planning, Civil Engineering and Ecology The Ministry of Spatial Planning, Civil Engineering and Ecology performs public administrative activities falling under competence of the Republic of Srpska related to spatial planning, construction and the environment. The Ministry develops and proposes laws and other regulations under its authority, provides opinions on the law proposals and carries out other activities in accordance with the Constitution and the law. www.vladars.net/eng/vlada/ministries/MSPCEE/Pages/ default.aspx 
Republic Institute for the Protection of Cultural, Historical and Natural Heritage

The Republic Institute forms part of the Ministry of Education and Culture of the Republic of Srpska. The Institute carries out administrative and other professional tasks related to identifying, recording, researching, and valuating sites for protection, identifying properties of cultural, historical and natural heritage, keeping the registry of protected properties, approving expert studies for restoration, reconstruction and preservation of cultural, historical and natural heritage, professional supervision of organizations for protection, and other duties stipulated by the applicable regulations.

http://nasljedje.org

\section{CROATIA}

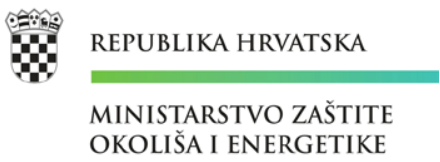

\section{Ministry of Environment and Energy}

The Ministry of Environment and Energy performs tasks related to the protection and conservation of the environment and nature in line with the sustainable development policy of the Republic of Croatia, as well as tasks related to water management, and administrative and other tasks in the field of energy. The main goal of the Ministry is to create conditions for achieving sustainable development goals by utilizing the natural and cultural wealth, and the human resources of the Republic of Croatia within the framework of a modern European society. www.mzoip.hr

\section{Croatian Agency for the Environment and Nature}

Croatian Agency for the Environment and Nature (CAEN) is the central national level government agency responsible for data collection and technical expertise in the field of environment and nature conservation. It collects data on environment and nature, analyses it and reports on state of environment and nature. Agency also participates in development and implementation of relevant sectorial strategies and policies.

www.haop.hr

\section{MACEDONIA}

Република Македонија

Министерство за животна средина и просторно планирање

\section{Ministry of Environment and Physical Planning}

The Ministry of Environment and Physical Planning is a governmental executive authority entrusted with the protection of the environment through drafting and enforcing regulations based on laws passed by the Macedonian Parliament. The Ministry is the main state institution responsible for the nature conservation sector, with a mandate to develop and implement relevant policies, conserve and manage biological and landscape diversity and natural heritage, and control and supervise the enforcement of the provisions of the Nature Protection Act. The mission of the Ministry is based on care for nature, environmental sustainability, and spatial planning through the fulfilment of European Union standards using the best practices and experiences, and in cooperation with citizens and other national and international institutions.

www.moepp.gov.mk

\section{MONTENEGRO}

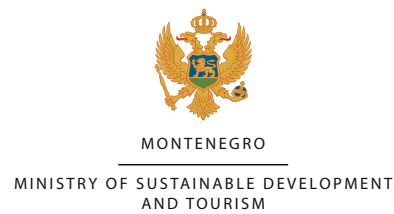

Ministry of Sustainable Development and Tourism The Ministry of Sustainable Development and Tourism is the main governmental authority responsible for policymaking on the environment and sustainable development. The portfolio of the Ministry includes the environment, nature protection, spatial planning, construction, tourism, housing, and coordination of international cooperation and management of the European Union funds in relevant areas.

\section{www.mrt.gov.me}

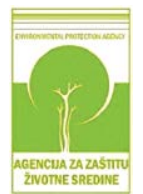

\section{Environmental and Nature Protection Agency}

The Environmental and Nature Protection Agency is the key institution for the implementation of nature protection regulations aligned with the European Union Directives. The Agency is responsible for issues concerning the monitoring of natural habitats and species, development of nature protection studies in the process of establishing protected areas, preparation and implementation of monitoring, preparation and maintenance of an environmental database (including biodiversity data) and issuance of all types of permits relating to nature protection. The Agency also collects data and prepares documents for the establishment of an ecological network.

www.epa.org.me 


\section{SERBIA}

РЕПУБЛИКА СРБИЈА

Министарство заштите животне средине

REPUBLIC OF SERBIA

Ministry of Environmental Protection

\section{Ministry of Environmental Protection}

The Ministry of Environmental Protection is the government authority responsible for the protection of environment and nature, field inspections of environmental protection, implementation of the Aarhus Convention, climate changerelated issues, transboundary air and water pollution, water pollution prevention, identification of environmental requirements in spatial planning and construction, protection against major chemical accidents, and participation in the response in the event of chemical accidents.

\section{www.ekologija.gov.rs}

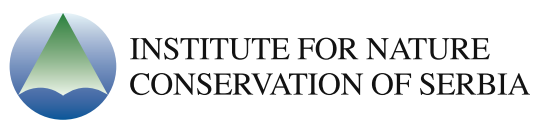

\section{Institute for Nature Conservation of Serbia}

The Institute for Nature Conservation of Serbia is a professional institution that carries out activities in the field of protection and improvement of the natural heritage of the Republic of Serbia. During several decades of the Institute's work, special attention has been given to developing cooperation with international organizations, scientific and professional institutions, protected area managers in other countries, and secretariats of the relevant international conventions, with the aim of exchanging experience and knowledge in the field of nature conservation and applying contemporary international principles and standards in nature conservation.

www.zzps.rs

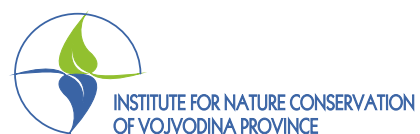

Institute for Nature Conservation of Vojvodina Province The Institute for Nature Conservation of Vojvodina Province is a specialized institution responsible for the protection of nature and natural resources in the Autonomous Province of Vojvodina. It functions within the Institute for Nature Conservation of Serbia, with the main activities of monitoring and evaluating the state of nature, drafting studies for the valuation of proposed protected areas, drafting documents related to nature protection, supervision in protected areas, and other tasks defined by the Nature Protection Act.

www.pzzp.rs

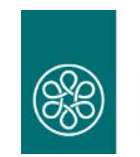

INSTITUTE OF THE REPUBLIC OF SLOVENIA for Nature Conservation

\section{Institute of the Republic of Slovenia for Nature Conservation}

The Institute is the main, national, professional organization in the field of nature conservation. Seven regional units provide highquality coverage of the terrain for the entire territory of Slovenia. The work of regional units is rounded off by the central unit in Ljubljana, which is responsible for coordination, standardisation of methods and uniform functioning of the Institute outwards and inwards. The Institute provides professional support for decisions of the government and other public institutions, prepares expert opinions in planning procedures of plans and projects in nature and participates in the management of protected areas. The Institute is also responsible for the implementation of various international conventions and European Directives and also carries out tasks related to the management of Natura 2000. The Institute educates and raises awareness about the importance of nature conservation and sustainable coexistence of man and nature. www.zrsvn.si

\section{Eco Horizon}

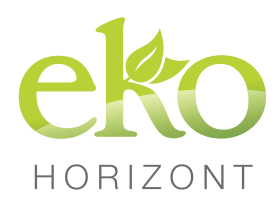

Eco Horizon is an independent, non-profit association for nature conservation, environment and sustainable development. Established in 2010 in Croatia, the mission of Eco Horizon is to promote the conservation of nature with its ecosystem services and cultural values, encourage sustainable management of natural resources, and support development of transboundary conservation initiatives. Eco Horizon's experts have extensive international experience in diverse aspects of nature conservation and sustainable development. Some of its members are part of the World Commission on Protected Areas (WCPA) of the International Union for Conservation of Nature (IUCN), while the founder of Eco Horizon also serves the function of Chair of IUCN WCPA Transboundary Conservation Specialist Group.

\section{www.ekohorizont.hr}





\section{Table of contents}

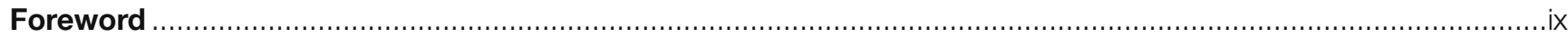

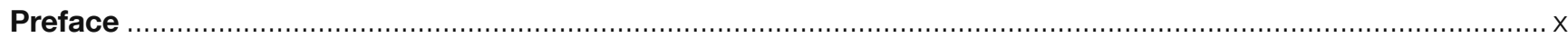

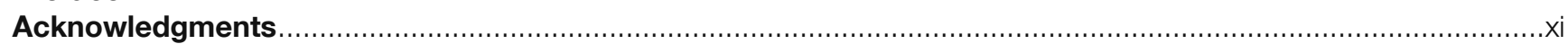

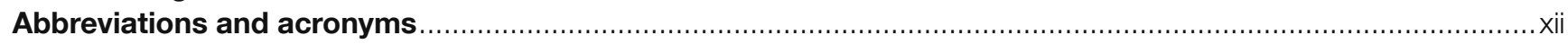

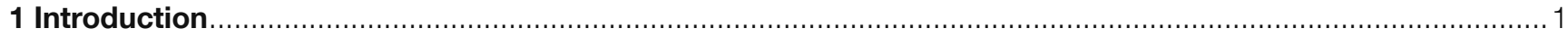

1.1 Towards strengthened conservation planning in South-Eastern Europe: project objectives ............................ 2

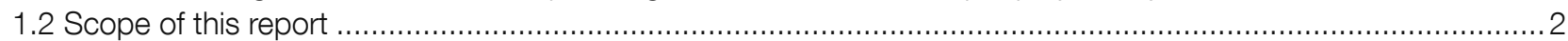

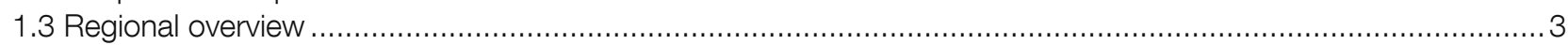

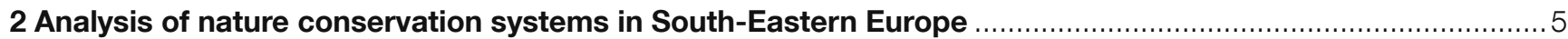

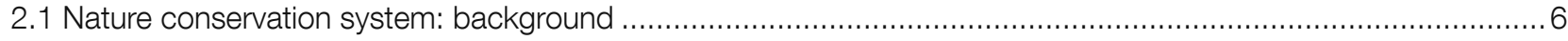

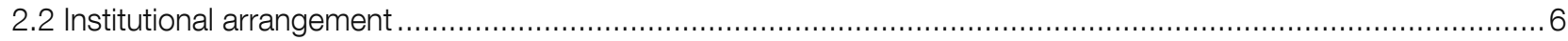

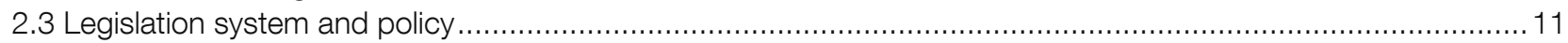

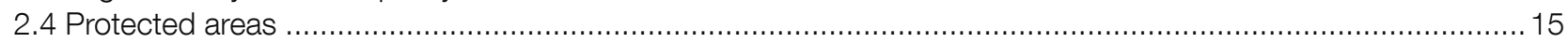

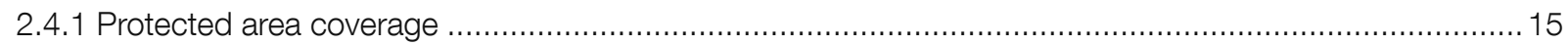

2.4.2 Application of IUCN protected area management categories in the region ...................................... 17

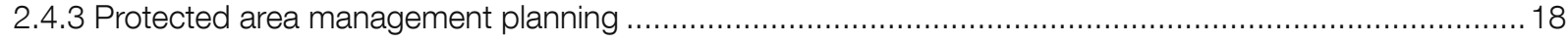

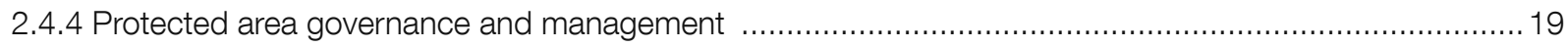

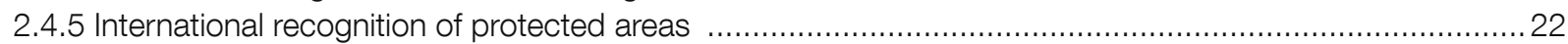

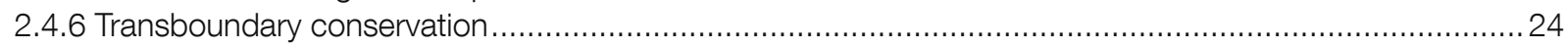

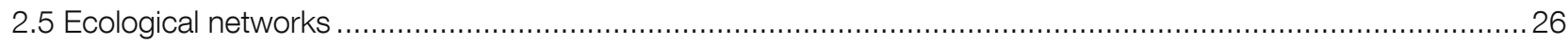

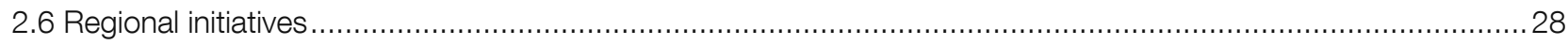

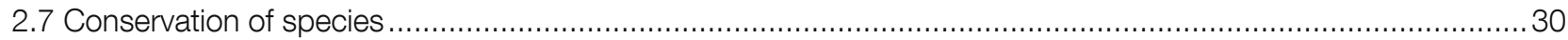

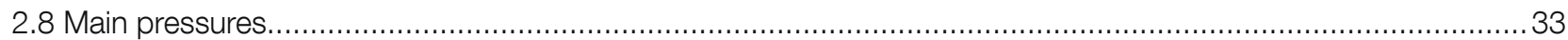

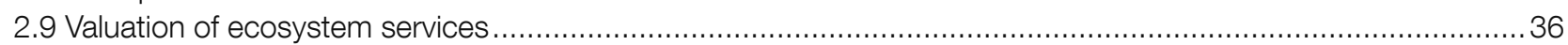

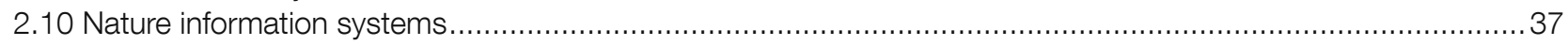

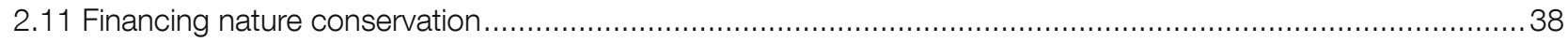

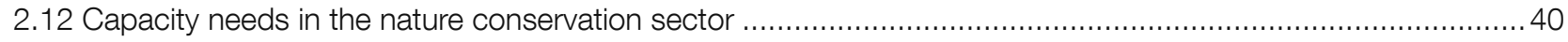

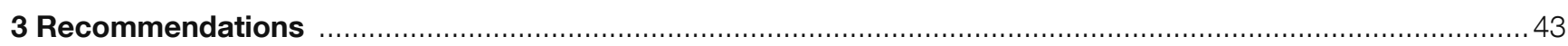

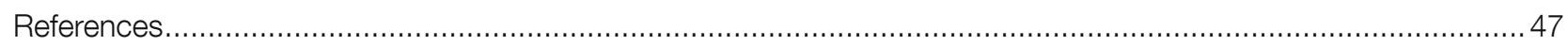

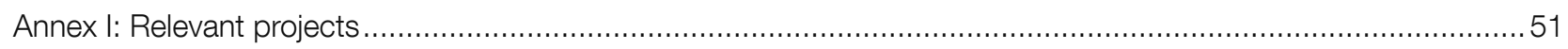




\section{Tables}

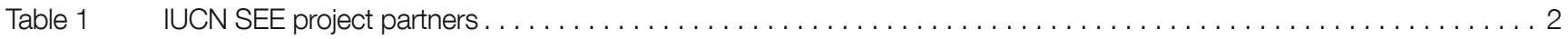

Table 2 Main state-level institutions responsible for nature conservation in the SEE countries $\ldots \ldots \ldots \ldots \ldots \ldots \ldots$

Table 3 Adoption status of the main national legislation relevant for nature conservation in the SEE $\ldots \ldots \ldots \ldots \ldots \ldots$

Table $4 \quad$ Multilateral treaties relevant for nature conservation ratified in SEE by $2017 \ldots \ldots \ldots \ldots \ldots \ldots$

Table 5 Adopted National Biodiversity Strategy and Action Plans in the SEE countries $\ldots \ldots \ldots \ldots \ldots \ldots \ldots$

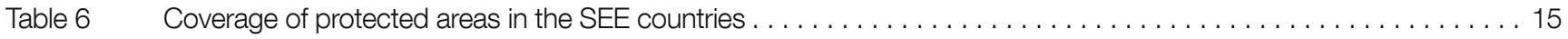

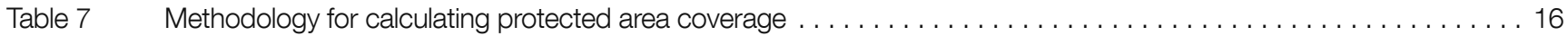

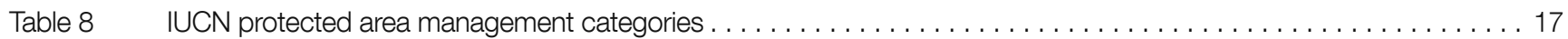

Table $9 \quad$ Surface under IUCN protected area management categories in the SEE countries $\ldots \ldots \ldots \ldots \ldots$

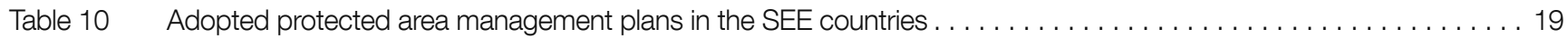

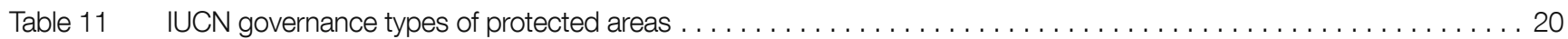

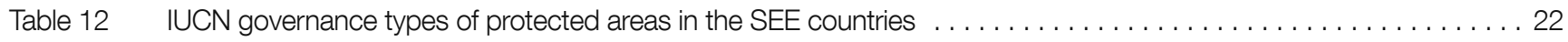

Table 13 International conventions and programmes recognising protected area values in the SEE region . . . . . . . . . 23

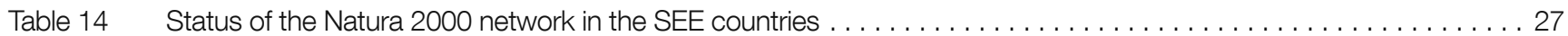

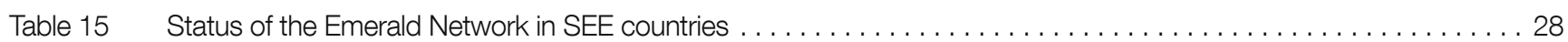

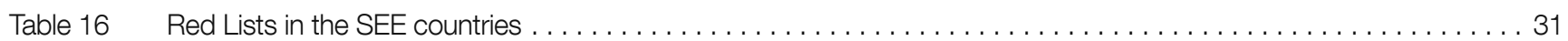

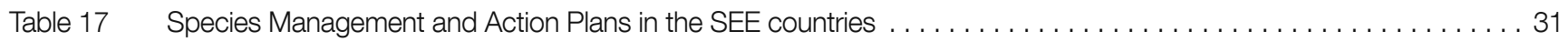

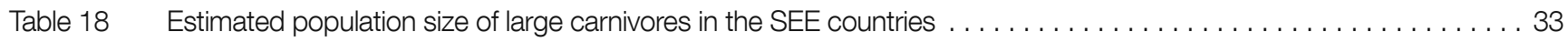

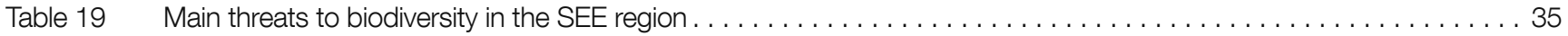

Table 20 Environmental information systems managed by government institutions in the SEE countries . . . . . . . . . . 38

Table $21 \quad$ Funding sources for nature conservation sector in the SEE region $\ldots \ldots \ldots \ldots \ldots \ldots \ldots \ldots$

Table 22 Main capacity needs for strengthening nature conservation in the SEE countries $\ldots \ldots \ldots \ldots \ldots \ldots \ldots \ldots$

\section{Figures}

Figure 1 Protected area coverage in SEE countries as reported by countries (A) and with harmonized methodology (B) . . . . 16

Figure 2 Overall surface of protected areas assigned with IUCN protected area management category in the SEE region . . . 18

Figure 3 Percentage of existing management plans for national parks in the SEE countries . . . . . . . . . . . . . 19

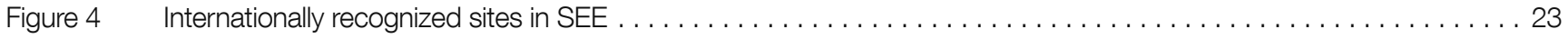

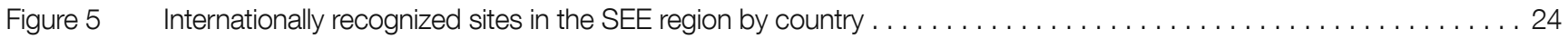

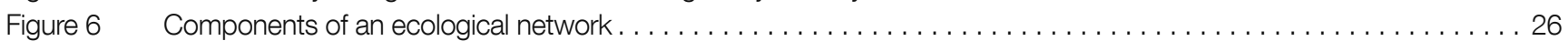




\section{Foreword}

Featuring abundant freshwater resources, unique extensive karstic systems, and a high level of biodiversity and endemism, the South-Eastern Europe stand out as a conservation priority for Europe. At MAVA, we recognise the patrimonial value of the region's biodiversity and natural capital and focus on nature conservation in the Mediterranean part of the region, addressing in particular the challenges of hydropower development, transboundary conservation and illegal killing of migratory birds.

Since 2013, we have been supporting the project 'Towards strengthened conservation planning in South-Eastern Europe' coordinated by IUCN ECARO with the objective of improving the implementation of nature conservation in the region. The project, carried out in cooperation with state authorities and agencies, aims to define national and regional conservation priorities and then to plan effectively to address these priorities. Such a process calls for a baseline assessment of the nature conservation sector in the region. State of nature conservation systems in South-Eastern Europe provides this baseline by offering an overview of institutional and legal frameworks, existing protected areas, ecological networks and regional initiatives for nature conservation in the region.

As the report also reflects on the level of operationality of nature conservation systems in each country, it offers a benchmark upon which governmental bodies, civil society organisations and donors alike can build to improve on conservation delivery in South-Eastern Europe. In this regard, and from a donor point of view, I find the sections describing capacity building needs in each country and those on institutional mechanisms established to finance nature particularly useful. They point to where and how external support could be provided to reinforce conservation in the region.

Another important message that clearly emerges from this report is that a transregional approach to conservation is particularly relevant in South-Eastern Europe, where large ecological landscapes cut across numerous national boundaries. Fortunately, transboundary approaches should be facilitated by the similarities that the report describes between the national administrative structures, which many of the countries of the region inherited from their common history.

I would like to warmly congratulate Maja Vasiljević, Sanja Pokrajac, Boris Erg and their collaborators for providing such a clear, complete and unbiased state-of-the-art of today's nature conservation assets and challenges in South-Eastern Europe. Producing regular snapshots of the state of conservation and of the efficiency of conservation frameworks and apparatus as a base from which progress can be made is central to IUCN's mission. This report does it brilliantly.

Lynda Mansson

Director General

MAVA Foundation 


\section{Preface}

The State of nature conservation systems in South-Eastern Europe is the first comprehensive attempt to collate all the relevant information on institutional arrangements for nature conservation in the region into one coherent report. It is aimed at helping decision-makers, experts and the donor community to shape and implement policies, strategies and programmes with a view to strengthening nature conservation systems and making them as resilient and impactful as possible.

The countries in the region have come a long way since the emergence of the new, independent institutional systems, and their integration into international environmental policy and sustainable development processes. Departing from the rather unified systems rooted in the past, the last two decades have brought a wealth of new approaches in the design of institutional frameworks, enabling them to deal with an increasing range of environmental commitments at the national and international level.

In the same time, countries are expected to meet a number of global and regional policy targets, from the UN Sustainable Development Goals (SDGs), the Paris Agreement and biodiversity-related conventions, to the EU nature acquis. There is strong demand for these countries to respond to an ever-growing call for mainstreaming nature into sectoral policies. In addition, there is a growing expectation for transparency, inclusiveness, and accountability expressed by the local communities and civil society, private sector, and development agencies and the international community.

With an exceptional diversity and richness of ecosystems found all across South-East Europe, embodied in four of the eleven biogeographical regions occurring in Europe, the region clearly stands out on the map of ecologically rich and biodiversity important areas. Counterbalancing these values, there is an increasing demand for energy production facilities, infrastructure and urban areas. This new development paradigm poses a range of threats on natural ecosystems and prompts the question of institutional resilience, the need for improved cross-sectoral cooperation and regional dialogue.

The State of nature conservation systems in South-Eastern Europe report aims to review the health of the national nature conservation systems, their suitability for purpose, the main gaps and opportunities in delivering on the many national and international policy targets, and their coherency with respect to addressing regional commonalities and priorities. Despite the national specificities, the countries in South-Eastern Europe have much in common when it comes to environmental challenges and sustainable development goals. Enabling the countries to embrace this approach and effectively manage ecosystems in a transboundary and regional context, and to create shared policy, planning, and management frameworks, is a precondition and key for the region's sustainable future.

Finally, we would like to take this opportunity to thank the MAVA Foundation for recognizing the need for strengthened regional cooperation in nature conservation through institutional development, and consolidated information and knowledge sharing.

Cyrie Sendashonga, Global Director, IUCN Policy and Programme Group
Boris Erg, Director, IUCN Regional Office for Eastern Europe and Central Asia (ECARO) 


\section{Acknowledgments}

We wish to thank all the partners in the 'Towards strengthened conservation planning in South-Eastern Europe' project who provided valuable support in the development of this report. It was an arduous task and would not have been possible without the involvement of relevant institutions responsible for nature conservation in South-Eastern Europe. We give warm thanks to all the authors of the national reports, who provided insights into the nature conservation systems in their countries, and whose hard work has served as the foundation of this report. These include: Vasil Anastasovski, Milena Bataković, Ferdinand Bego, Taulant Bino, Patricija Gambiroža, Tjaša Đokić, Martina Kačičnik Jančar, Tadej Kogovšek, Goran Krivanek, Srđan Marinčić, Ajla Mehmedović, Biljana Opačić, Ivana Plavac, Dejan Radošević, Goran Sekulić, Nataša Stanišić, Gabrijela Šestani, Petra Štrbenac, Sara Todorović, Ramona Topić, Marija Trikić, Marko Tucakov, Azra Velagić and Irina Zupan. We are also grateful to all our institutional partners in South-Eastern Europe.

We also wish to acknowledge the support of Jelena Dučić, Saško Jordanov, Klodiana Marika, Andrej Sovinc and Vlatko Trpeski for their reviews of the national reports and continuous provision of feedback during report development. We are very grateful to peer reviewers, Petr Roth and Jernej Stritih, for their excellent and critical review, and Tomasz Pezold, who provided additional recommendations for improvement of the report. We also thank the photographers, who have contributed beautiful photos for this publication, and the proofreader of this volume, Linda Zanella.

Our very special gratitude goes to the MAVA Foundation, for providing the funding for the 'Towards strengthened conservation planning in South-Eastern Europe' project that this report is part of, and for its continued dedication to supporting nature conservation in the South-Eastern European region. 


\section{Abbreviations and acronyms}

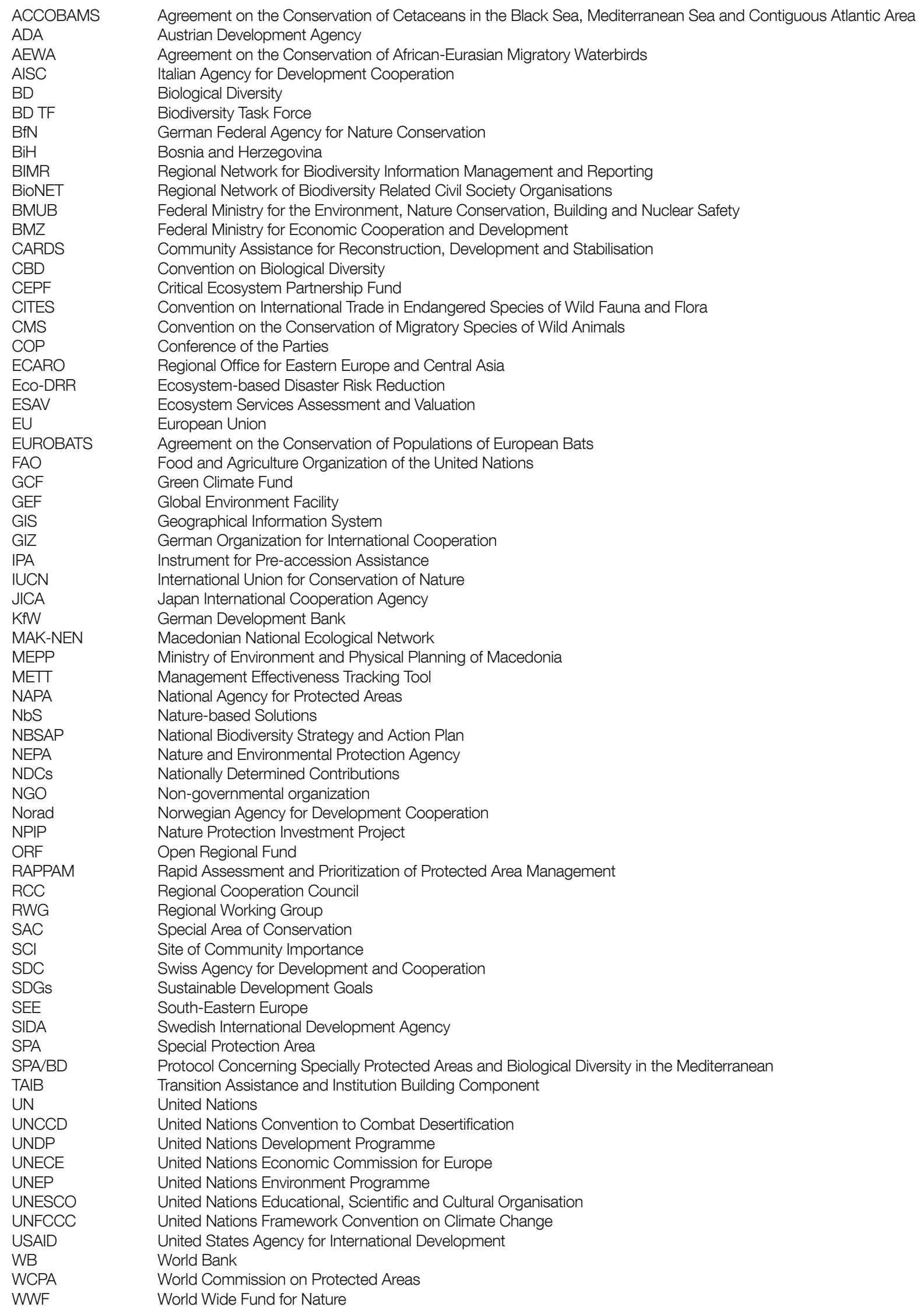




\section{Introduction}

\section{Maja Vasilijević}

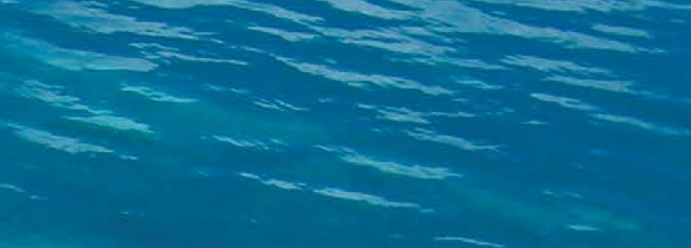




\subsection{Towards strengthened conservation planning in South-Eastern Europe: project objectives}

In autumn 2013, the International Union for Conservation of Nature (IUCN) - then the Programme Office for South-Eastern Europe (SEE), and currently the IUCN Regional Office for Eastern Europe and Central Asia (ECARO) - initiated the project 'Towards strengthened conservation planning in SEE' with the objective of strengthening the implementation of nature conservation standards in the SEE region, by supporting institutional development and creating a regional platform for nature conservation planning. To achieve this, IUCN has been working closely with national nature conservation authorities and partners from seven countries in the region, as shown in Table 1.

\section{Table 1 IUCN SEE project partners}

\begin{tabular}{|l|l|}
\hline Country & Institution \\
\hline Albania & Ministry of Environment ${ }^{1}$ \\
\hline Croatia & $\begin{array}{l}\text { Federal Ministry of Environment and Tourism } \\
\text { Ministry of Spatial Planning, Civil Engineering and Ecology of Republic of Srpska } \\
\text { Republic Institute for the Protection of Cultural, Historical and Natural Heritage }\end{array}$ \\
\hline Macedonia & $\begin{array}{l}\text { Ministry of Environment and Energy } \\
\text { State Institute for Nature Protection }\end{array}$ \\
\hline Montenegro & Ministry of Environment and Physical Planning \\
\hline Serbia & $\begin{array}{l}\text { Ministry of Sustainable Development and Tourism } \\
\text { Nature and Environmental Protection Agency }\end{array}$ \\
\hline Slovenia & $\begin{array}{l}\text { Ministry of Agriculture and Environmental Protection } \\
\text { Institute for Nature Conservation of Serbia } \\
\text { Institute for Nature Conservation of Vojvodina Province }\end{array}$ \\
\hline
\end{tabular}

The three-year long project funded by MAVA Foundation has been implemented at both national and regional levels. At the national level, it supported nature conservation authorities in each country in effectively defining and addressing the conservation priorities. At the regional level, the project established a network of state authorities and conservation agencies, as a platform for defining and planning regional conservation priorities, and for sharing the knowledge and experience within and beyond the SEE region.

The project developed a capacity building programme for the regional stakeholders, including training workshops, exchange visits and study tours. It also included a baseline assessment of the state of nature conservation systems in the region, which is the key objective of this publication.

\subsection{Scope of this report}

The scope of this report is to assess and analyse the state of national nature conservation systems in seven SEE countries where the IUCN's project has been implemented, namely, in Albania, Bosnia and Herzegovina (BiH), Croatia, Macedonia, Montenegro, Serbia and Slovenia, including the assessment at regional level; and to recommend ways to improve the effectiveness and functionality of these systems. The report did not look into private companies or consultancies, nor the work of the individual experts. For the purpose of this report, the SEE region refers to these countries only, and does not include several other countries that geographically form part of the region.

\footnotetext{
1 The Ministry of Tourism and Environment was established in 2017.

Currently integrated within the Croatian Agency for Environment and Nature.

3 The Environmental Protection Agency was transformed into the Nature and Environmental Protection Agency (NEPA) in 2017. The core of the former Institute for Nature Protection is still maintained within the NEPA

4 The Ministry of Environmental Protection was established in 2017
} 
The report begins with introductory remarks and a regional comparison, analysis and synthesis of nature conservation systems, followed by summaries of national reports on the state of nature conservation systems in each country. In its conclusions, the report proposes the main recommendations for the future.

The report brings together a plethora of available information with the aim of enabling better understanding of the state of nature conservation systems in the SEE region. It draws upon targets, commitments and activities of countries as reported in their National Biodiversity Strategy and Action Plans (NBSAP), the Fifth National Reports to the United Nations (UN) Convention on Biological Diversity (CBD), and each country's Assessment of the State of Nature Conservation System (i.e. national reports). ${ }^{5} \mathrm{lt}$ also takes into account information on the status and trends related to nature and biodiversity as reported by countries and drawn from the scientific literature. All national-based information concerns the status concluding with January 2017.

\subsection{Regional overview}

The SEE region is characterized by rich biodiversity, including many endemic species, and relatively large unspoiled ecosystems. Three biogeographic regions extend over SEE; Continental, Alpine and Mediterranean, all having distinctive characteristics. Considering its biodiversity richness, SEE is one of the most abundant regions in Europe. Relatively extensive and well-preserved forests throughout the region offer shelter to significant populations of large carnivores, such as brown bear (Ursus arctos), wolf (Canis lupus) and lynx (Lynx lynx). The karst ecosystem is the largest in Europe, and contains a significant underground freshwater reservoir. Wetlands and freshwater habitats host important nesting populations of numerous endangered bird species. The region is bounded to the south-west by the Adriatic Sea that contains a variety of coastal and marine habitats with reefs, caves, rocks and archipelagos, and meadows of Neptune grass (Posidonia oceanica).

The SEE region experienced a turbulent recent political history, with armed conflicts involving several countries. The political complexity of the region is still visible today, especially in $\mathrm{BiH}$, which is divided into two entities and one district, all with their own government structures.

In terms of the European Union (EU), countries differ in their accession status. The region includes full EU Member States (Croatia and Slovenia), Candidate countries (Albania, Macedonia, Montenegro, and Serbia), and a Potential candidate country $(\mathrm{BiH})$.

The SEE region is intersected by many international boundaries, and diverse species and habitats span across them, indicating the need for conservation planning and management at the transboundary level. Differing institutional and governance arrangements for nature conservation in the SEE region do not necessarily address priority issues at the regional and transboundary levels. Knowledge and experience sharing play a key role in the alignment of priorities and definition of joint conservation actions.

5 See references: Anastasovski (2014); Bataković and Staničić (2014); Bino and Bego (2014); Đokić (2014); Radošević and Todorović (2014); Sekulić, Marinčić, Trikić, Tucakov (2014); Velagić, Radošević, Todorović (2014); Zupan, Opačić, Šestani, Gambiroža, Plavac, Štrbenac, Topić, Krivanek (2014). In this report, when referring to the noted references, the term 'national reports' will be used. 


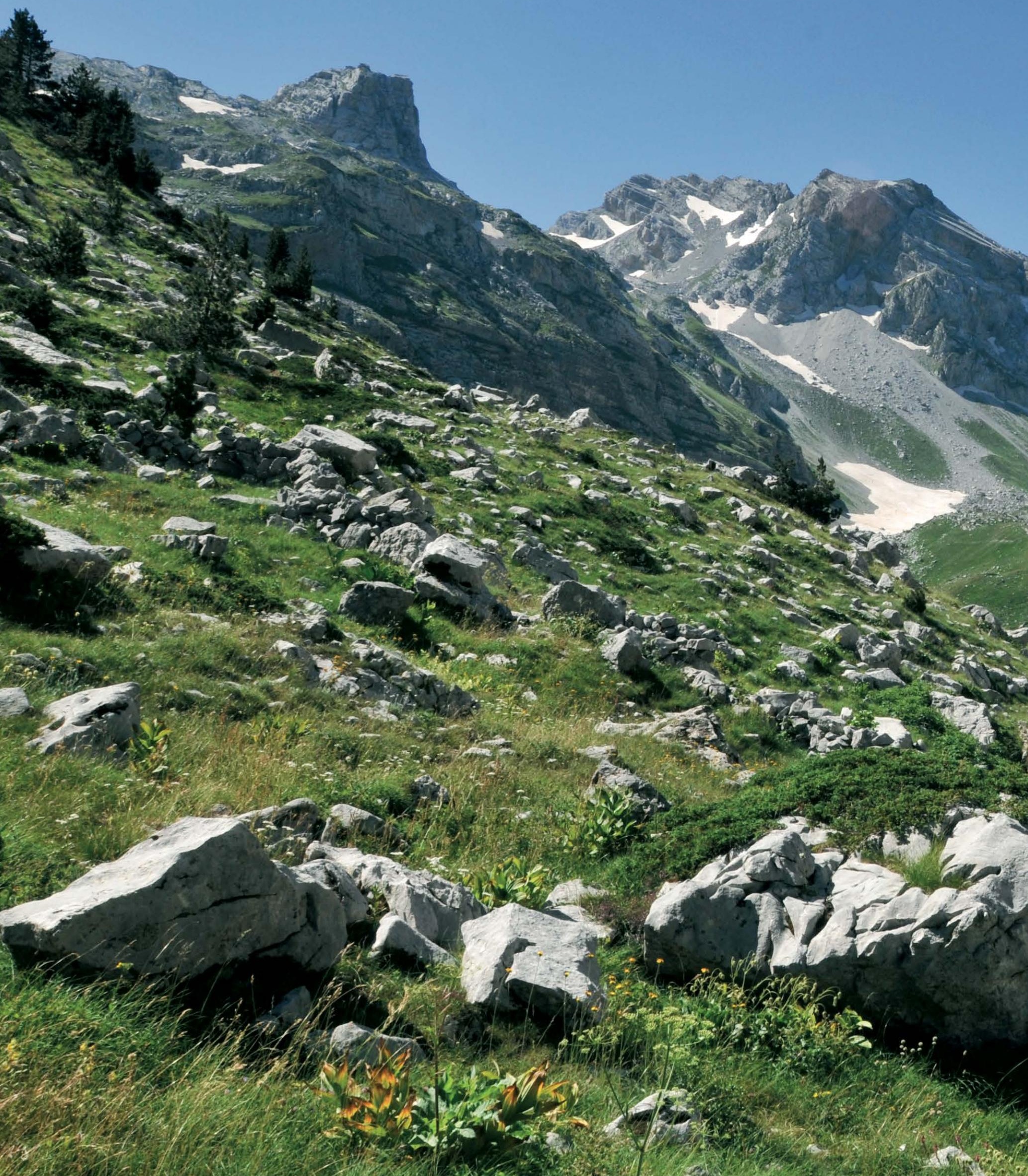




\section{Analysis of nature conservation systems in South-Eastern Europe}

\section{Maja Vasilijević}

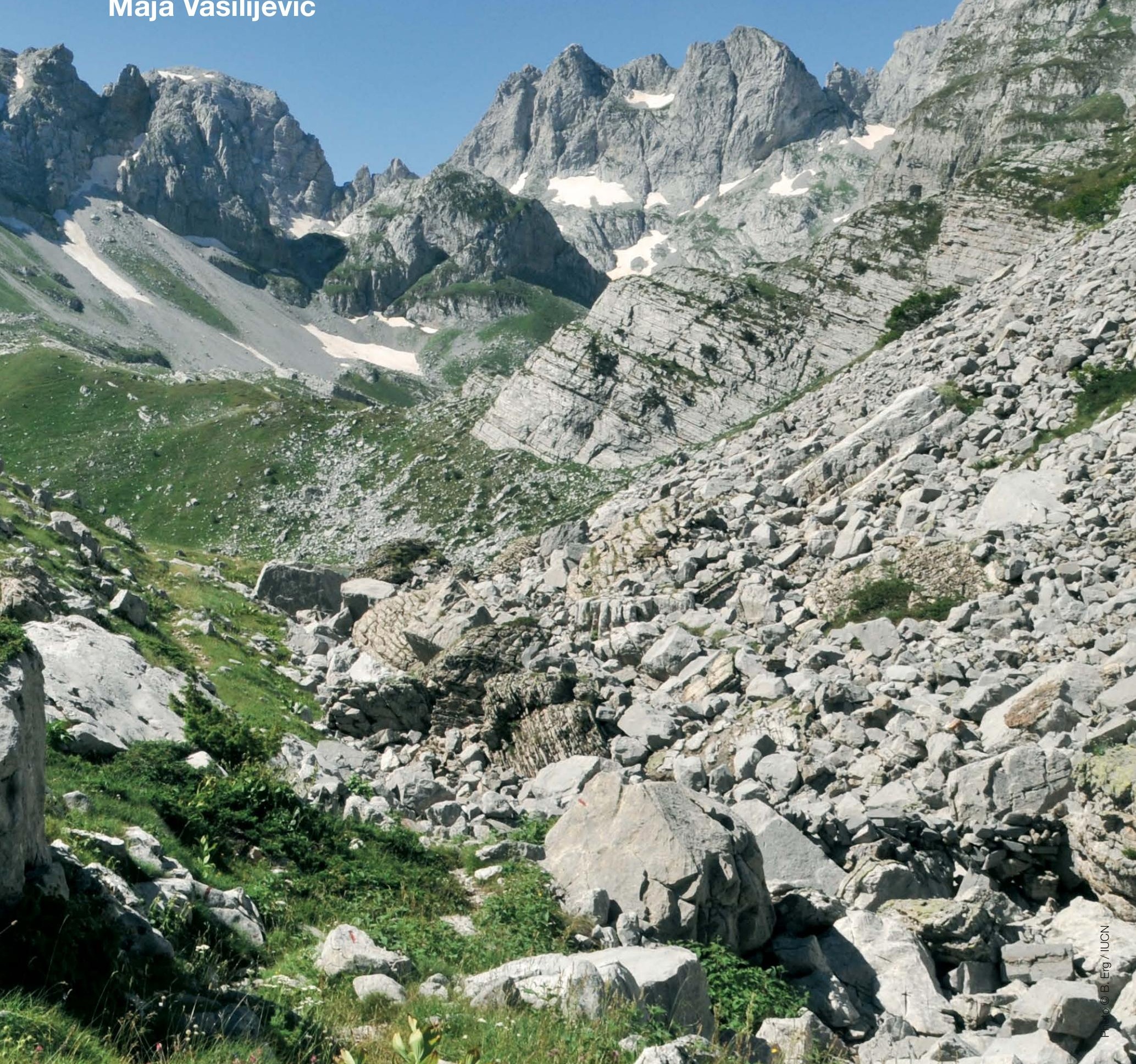




\subsection{Nature conservation system: background}

The Earth's biological diversity is a cornerstone of life and its importance for society is invaluable. At the same time, threats to species and ecosystems have never been as great as today. The international community has been increasingly aware of the importance of sustainable development to safeguard nature. A positive approach towards nature conservation needs to be expanded as part of the effort to tackle the loss of biodiversity, which ultimately affects the societies and their economies. Action to reduce the negative impacts on biodiversity and ecosystems can support a broad range of social benefits and lay the groundwork for the socio-economic transition to a more sustainable and inclusive model of development. Under this model, the economic value of biodiversity is directly accounted for, providing policymakers with very real incentives to ensure that our forests, oceans, rivers and the rich variety of species contained within are managed responsibly.

The broad term 'nature conservation system' refers to an enabling structure for effective and efficient governance and management of nature, including policy, institutions, legislation, protected areas, ecological networks and other effective nature conservation measures (e.g. management of species). The enabling structure or functions that provide a framework for national nature conservation systems relate to many different relevant elements, usually including:

- Institutional system: existence and efficiency of relevant governmental institutions, strength of the non-governmental sector, institutions performing research on biodiversity and conservation

- Legislation: existence and enforcement of relevant laws, procedures for designation of conservation sites (e.g. protected areas, Emerald Network, Natura 2000)

- Nature conservation policy: main policies and conservation priorities, multilateral treaties

- International cooperation: regional initiatives and transboundary conservation

- Financing: main sources of funding and its sufficiency

- Conservation measures in protected areas: meeting the objectives of protected area designation

- Protected area management planning: existence and implementation of management plans, participatory approach in the development of management plans

- General conservation measures: ecological networks, conservation of species, mainstreaming of nature conservation into other sectors such as agriculture, fishery, forestry, hunting, water management, urban development

- Monitoring and reporting: adequacy of monitoring and reporting

- Capacity: availability of human resources, including skills and knowledge, in the nature conservation sector.

These functions have been assessed to a greater or lesser extent in the following chapters of this report, depending on the availability of information. In addition to the above set of functions, any future revision of the report should seek to include elaboration of the status of information dissemination and public education as to assess the general public stance towards nature and nature conservation, potential disputes between protected area management authorities and local communities, and investors and conservation authorities.

The assessment of national nature conservation systems and the analysis at the regional level enables better understanding of the gaps and the need to overcome specific challenges for strengthening conservation measures and improving conservation outcomes.

\subsection{Institutional arrangement}

Strong institutions are one of the key prerequisites for effective nature conservation. Successful management of nature includes well organized cooperation of all institutions involved in nature conservation, consolidated, integrated and evidencebased information on biodiversity, and appropriate socio-economic indicators. The cross-sectional, vertical and horizontal coordination of institutions is an essence of the functional nature conservation system.

Table 2 summarizes the institutional framework in the SEE countries. Evidently, not all of the mentioned institutions are present in all countries, potentially creating a gap for successful nature conservation systems. The structure and number of employees working in the nature conservation sector also vary significantly among countries. Political changes in some countries often entail frequent replacement of staff members, resulting in a loss of continuity and lower capacity of newly employed professionals. Insufficient technical capacity has also been noted in several national reports.

A well-rounded institutional system would ideally include three relevant institutions, i.e. the ministry, an expert-based technical institution (commonly called 'the institute' in SEE countries) and protected area management authority/ies. This system could be complemented by an environment fund and an environment agency, provided there is efficient coordination between the primary group of institutions and these two bodies. Furthermore, the agenda of environment 
funds and environment agencies often excludes nature conservation and focuses on the "grey" environment, thus making their contribution and relevancy for nature conservation sector marginal.

Ministries, with jurisdiction over nature conservation issues, exist at the national level in all countries. Considering the specific political arrangement in $\mathrm{BiH}$, there are also ministries functioning at the entity and cantonal levels in this country.

The presence of institutes as independent technical institutions responsible for nature conservation varies from country to country. Institutes exist in Serbia (Institute for Nature Conservation of Serbia, Institute for Nature Conservation of Vojvodina Province) and in Slovenia (Institute of the Republic of Slovenia for Nature Conservation).

Croatia experienced changes in 2015 when the Croatian government adopted a decree merging the State Institute for Nature Protection and Croatian Environmental Agency into the Croatian Agency for Environment and Nature. Although these institutions have been integrated, data on both the former State Institute for Nature Protection and the former Croatian Environmental Agency is provided separately in the national report in Chapter 3, as per the submitted national report.

In 2012, Montenegro experienced similar changes when the former Institute for Nature Protection became part of the Nature and Environmental Protection Agency (NEPA).

Several other countries also experienced changes in relation to their formerly independent institutes. In $\mathrm{BiH}$, in $1995 \mathrm{the}$ Republic Institute for the Protection of Cultural, Historical and Natural Heritage, established in 1976, became a department within the Republic of Srpska's Ministry of Education and Culture. The responsibilities of the Republic Institute remain quite independent within the ministry. Another institution that partially works on nature conservation in $\mathrm{BiH}$ (Institute for the Protection of Cultural-Historical and Natural Heritage of Sarajevo Canton) functions at the cantonal level.

In 1999, in Macedonia, with the establishment of the Ministry of Environment and Physical Planning (MEPP), the formerly independent Institute for the Protection of Natural Rarities continued its work within the MEPP. In 2016, a feasibility study on the potential to establish an institute for nature conservation was drafted.

According to the national reports consulted for this analysis, all countries have recognized the potential value and the need to have an expert-based technical institution for nature conservation. As shown in Table 2, such institutions do not exist in Albania, the Federation of $\mathrm{BiH}$ at the entity level, and Macedonia.

The institutes are commonly responsible for developing nature conservation-related inventory, monitoring and assessing the state of nature, providing technical expert opinions and developing relevant studies (greater detail in Chapter 3). Countries without an institute in place are faced with common issues such as deficiency in biodiversity-related inventories, poor or absent biodiversity monitoring programmes and information systems (databases), while usually understaffed ministries are in charge of generating reports on the state of nature (only in Montenegro is reporting a mandate of the Nature and Environmental Protection Agency). In SEE countries, the purpose of state administration, especially at the central level, is entirely different than managing technical and expert tasks, and thus it can hardly substitute the role of technical institutions.

One of the institutional mechanisms that could substantially contribute to funding nature conservation sector or its particular tasks is an environment fund. This type of institution usually receives revenues from various environmental taxes, special regulation fees, international loans and national or regional budgets. Common mechanism for financing projects by the fund is through soft loans with lower interest rates and longer repayment periods than the banks, and grants. Environment funds exist in $\mathrm{BiH}$ (one in the Federation of $\mathrm{BiH}$ (Environmental Protection Fund of the Federation of $\mathrm{BiH}$ ) and another in the Republic of Srpska (Environmental Protection Energy Efficiency Fund of the Republic of Srpska), Croatia (Environmental Protection and Energy Efficiency Fund) and Serbia (budgetary Green Fund). In Macedonia, the Environment Fund was closed in 2004.

All countries except $\mathrm{BiH}$ and Macedonia have environment agencies in place, with a common role being the collection, integration, and processing of environmental data, and submission of reports to the European Environment Agency. ${ }^{6}$

In comparison to other European countries, in the observed SEE countries responsibility for the management of different types of protected areas (above all national parks) is delivered by specialized public institutions (protected area authorities). They exist in all countries and their mandate may vary in terms of the spatial scale and type of protected areas they encompass. For example, the National Agency for Protected Areas (NAPA) is the responsible institution for managing the

6 All countries in the region are members or cooperating countries of the European Environment Agency. 
national system of protected areas in Albania. Unlike in other SEE countries, Montenegro has one single public institution ('enterprise' in this case, financed by the state budget) at the national level for management of all Montenegrin national parks (Public Enterprise for the National Parks of Montenegro). In BiH, Croatia, Macedonia, Serbia and Slovenia, there are no central public institutions, though separate public institutions are entrusted with the management of specific national parks (and for the management of other protected area categories in some of these countries, e.g. nature parks). In Croatia, public institutions function at the national (19 public institutions for national parks and nature parks), county (21 institutions) and local (5 institutions) levels. In $\mathrm{BiH}, 11$ public institutions and/or enterprises responsible for protected area management exist at the entity level (7 in the Federation of BiH and 4 in the Republic of Srpska). In Slovenia, apart from 7 national public institutions for national parks and nature parks, there is also one municipal (local) public institution. A more detailed review of protected areas and management structures for each country is presented in Chapter 3.

Relevant scientific, educational and other institutions (e.g. universities, natural history museums) are involved, to a certain extent, in nature conservation in all countries (for the lists of the most prominent institutions under this category, see the corresponding national reports in Chapter 3). In general, their activities are funded by the state budget or projects supported by national or foreign donors.

The scope of work of non-governmental organizations (NGOs) includes nature conservation activities and they are active in all SEE countries, in some more than in others. Largely, NGOs that work on wider environmental issues also include nature conservation activities in their scope of work, so it can be difficult to distinguish between them. Nevertheless, the national reports have noted an approximate number of the most active and professional NGOs specifically focusing on nature conservation, acknowledging that the list of the most prominent NGOs may not be complete.

According to the reported data, the widest nature conservation NGO scene is visible in Albania, Croatia, Serbia, and Slovenia. Of some 70 environmental NGOs in Albania, more than $70 \%$ deal with various aspects of nature conservation. The national reports for Croatia and Slovenia note that about 30 NGOs work on nature conservation issues in each of these countries. In Serbia, there are about 400 environmental NGOs, and according to the national report, some 10 organizations are most active. The national reports for $\mathrm{BiH}$, Macedonia, and Montenegro reported far fewer NGOs working on nature conservation than the other countries, nevertheless some seem to be strong and influential. It should be noted that the national reports did not provide information on the number of NGOs working in specific areas, e.g. whether they deal specifically with policy, environmental education, or scientific research work.

NGOs largely rely on the voluntary work of their members in all SEE countries, and sometimes they are fund-driven, thus shifting their area of interest based on available funding opportunities. Most of the nature conservation NGOs work on enhancing education and public awareness about nature values and the importance of their protection. Far fewer NGOs are also involved in research and monitoring, advocacy with the aim to influence policy, and other expert activities. 


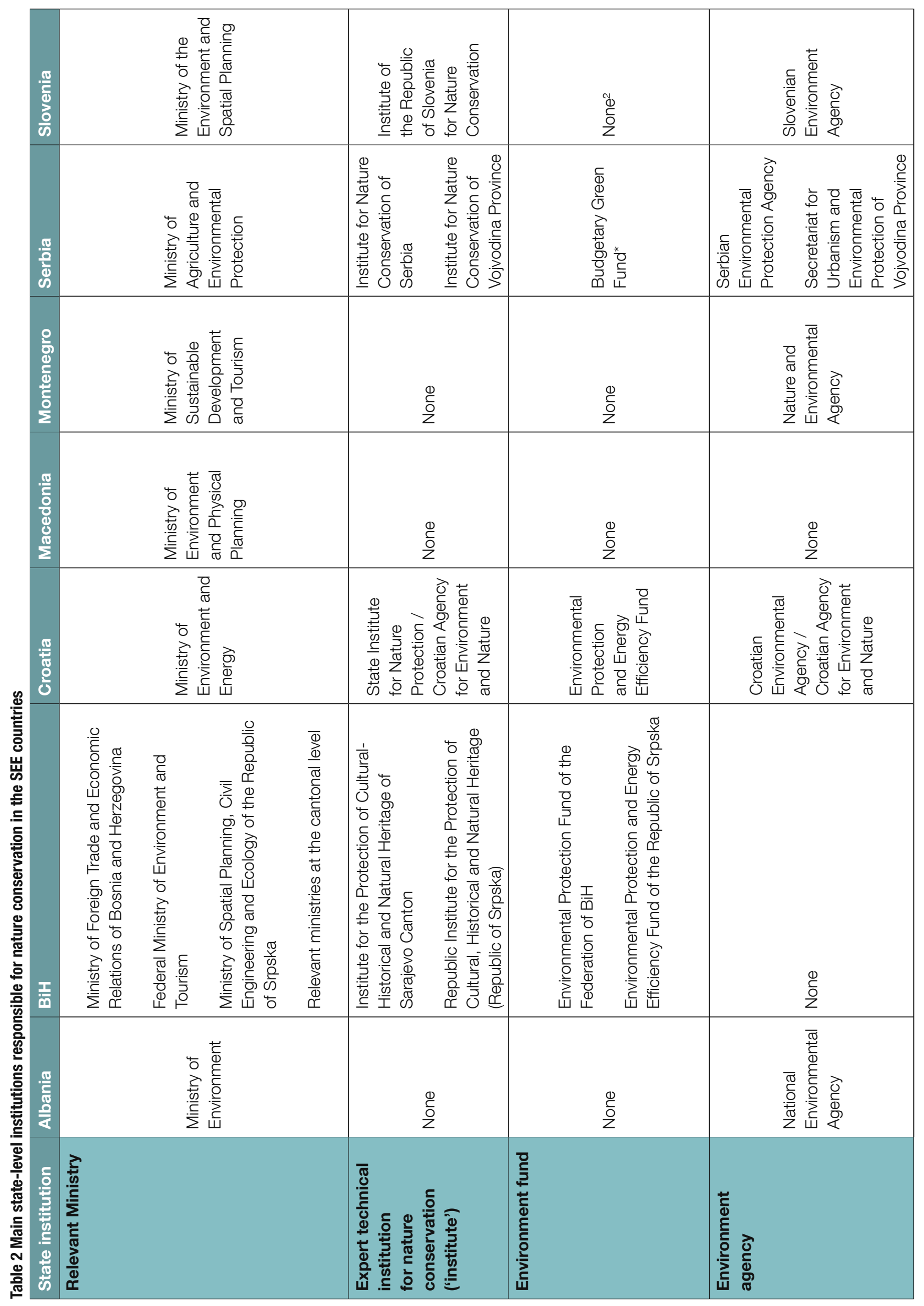




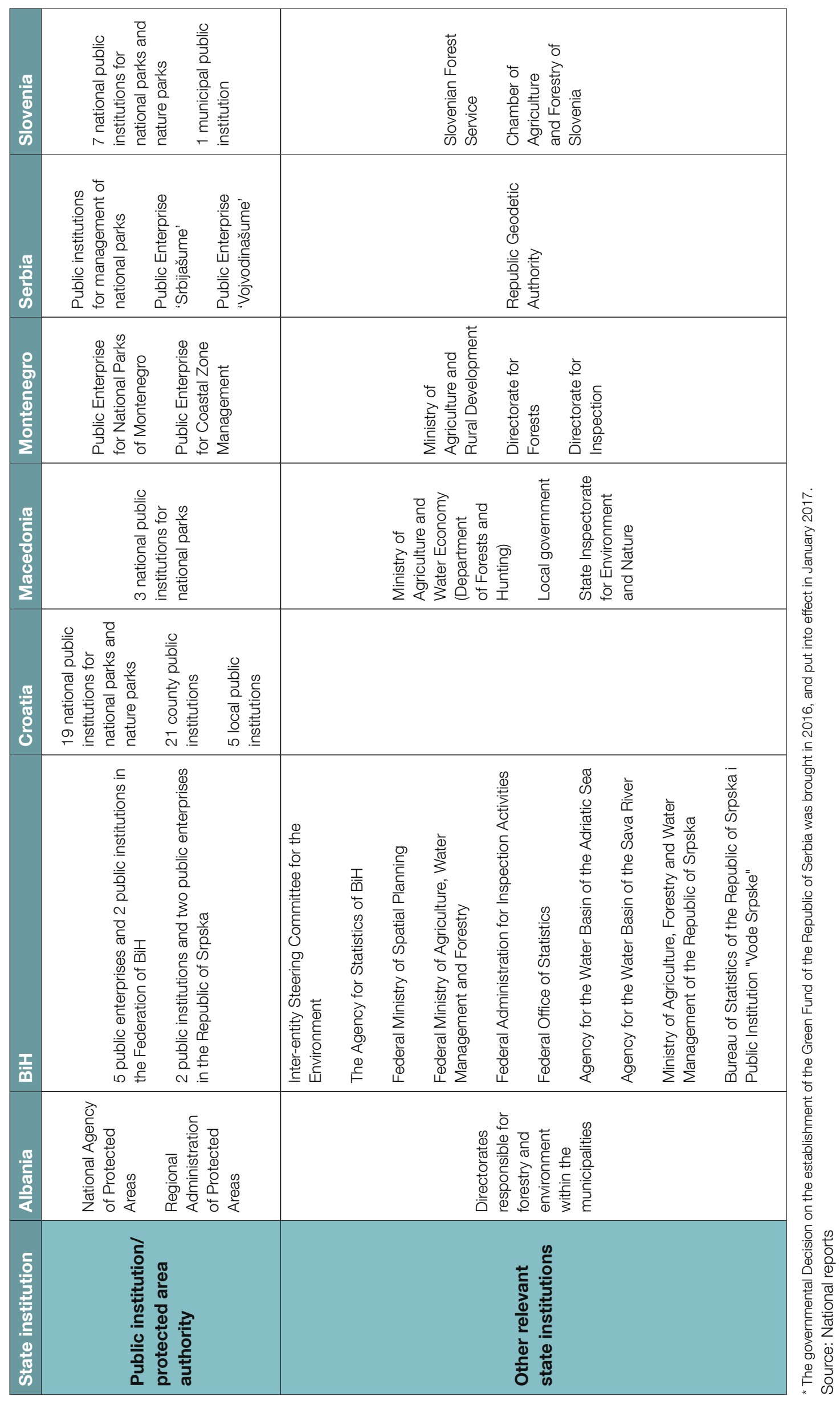




\subsection{Legislation system and policy}

\section{National laws}

It can be observed from Table 3 that all countries in the SEE have a legislation system in place to ensure care for nature and nature conservation. While an adequate legislation system in terms of existing laws and regulations exists in all the SEE countries, for the purposes of this report, the effectiveness of the system and implementation of the laws was not assessed.

The main law that regulates nature conservation, sustainable use of biodiversity, and protected area systems in all countries is the law on nature and/or biodiversity conservation/protection. Additionally, all countries have also adopted specific laws governing the proclamation of protected areas, mainly national parks. Apart from specific nature conservation or environmental laws, all countries also have a number of by-laws or decrees/decisions/ordinances/codes, which further regulate specific issues.

Unlike other SEE countries, the complex BiH political set-up has led to an absence of integration of the nature conservation legislation system at the national level. Hence, nature conservation is regulated through the laws adopted and implemented at the entity level and with no alignment at the national level.

All SEE countries also have operational laws in other sectors and that are relevant for nature conservation, e.g. laws on waters, forests, hunting. Nevertheless, the national reports stressed the need for better cross-sectoral cooperation.

Table 3 Adoption status of the main national legislation relevant for nature conservation in the SEE

\begin{tabular}{|c|c|c|c|c|c|c|c|c|}
\hline \multirow[b]{2}{*}{ National legislation } & \multirow[b]{2}{*}{ Albania } & \multicolumn{2}{|c|}{$\mathrm{BiH}$} & \multirow[b]{2}{*}{ Croatia } & \multirow[b]{2}{*}{ Macedonia } & \multirow[b]{2}{*}{ Montenegro } & \multirow[b]{2}{*}{ Serbia } & \multirow[b]{2}{*}{ Slovenia } \\
\hline & & $\begin{array}{l}\text { Federation } \\
\text { of } \mathrm{BiH}\end{array}$ & $\begin{array}{l}\text { Republic } \\
\text { of Srpska }\end{array}$ & & & & & \\
\hline $\begin{array}{l}\text { Law on nature protection/ } \\
\text { conservation }\end{array}$ & $\bullet$ & $\bullet$ & - & $\bullet$ & - & $\bullet$ & $\bullet$ & $\bullet$ \\
\hline Law on protected areas & $\bullet$ & & & & & & & \\
\hline $\begin{array}{l}\text { Law on environment/ } \\
\text { environmental protection }\end{array}$ & $\bullet$ & $\bullet$ & $\bullet$ & $\bullet$ & $\bullet$ & $\bullet$ & $\bullet$ & $\bullet$ \\
\hline $\begin{array}{l}\text { Law on designation of } \\
\text { specific protected areas }\end{array}$ & & $\bullet$ & $\bullet$ & $\bullet$ & $\bullet$ & $\bullet$ & $\bullet$ & $\bullet$ \\
\hline Law on waters & $\bullet$ & $\bullet$ & $\bullet$ & $\bullet$ & $\bullet$ & $\bullet$ & $\bullet$ & $\bullet$ \\
\hline Law on forests & $\bullet$ & $\bullet$ & $\bullet$ & $\bullet$ & $\bullet$ & $\bullet$ & $\bullet$ & $\bullet$ \\
\hline Law on hunting & $\bullet$ & $\bullet$ & $\bullet$ & $\bullet$ & $\bullet$ & $\bullet$ & $\bullet$ & $\bullet$ \\
\hline
\end{tabular}

Source: National reports

\section{Transposition of the EU Nature Directives}

The SEE countries are at different stages of transposition of the EU Nature Directives, namely Council Directive 92/43/ EEC on the conservation of natural habitats and of wild fauna and flora, i.e. the Habitats Directive (adopted in 1992), and Directive 2009/147/EC of the European Parliament and the Council on the conservation of wild birds, i.e. the Birds Directive (adopted in 1979, amended in 2009).

According to the national reports, Croatia and Slovenia, as EU Member States, have fully transposed the Habitats and Birds Directives. Of the remaining countries, Albania has transposed most of the Birds and Habitats Directives. BiH has made steady progress in the past several years, with a set of subordinate legislation pending adoption. It should be noted that in the case of $\mathrm{BiH}$, it is difficult to discuss transposition of the EU Nature Directives at the national level, since the laws exist only at the entity level. According to the national reports, transposition in Macedonia and Montenegro is progressing well. Both countries have made good progress with transposition of the Birds Directive. In Serbia, the process of transposition of the EU Nature Directives is nearing completion.

The progress of transposition of the EU's Birds and Habitat Directives should be taken with caution, as the methodology for their calculation does not provide much detail about the functional transposition of the EU Nature Directives. 


\section{Multilateral environmental treaties}

Most SEE countries are signatories to some of the most important international conventions and agreements relevant for nature conservation (see Table 4). The majority of multilateral treaties ratified by SEE countries are under the auspices of UN bodies, such as United Nations Environment Programme (UNEP), United Nations Educational, Scientific and Cultural Organisation (UNESCO), and United Nations Economic Commission for Europe (UNECE), while others are under the aegis of regional institutions, such as the Council of Europe and the International Commission for the Protection of the Danube River.

The geographic scope of the ratified treaties varies, including global and regional scales (including Europe and its subregions). For example, the Convention on Cooperation for the Protection and Sustainable Use of the Danube River encompasses the Danube River catchment countries, thus excluding Albania and Macedonia from being parties. Similarly, Macedonia and Serbia are not parties to the Convention for the Protection of the Marine Environment and the Coastal Region of the Mediterranean (Barcelona Convention), nor to the Agreement on the Conservation of Cetaceans in the Black Sea, Mediterranean Sea and Contiguous Atlantic Area (ACCOBAMS).

Regarding global multilateral treaties, $\mathrm{BiH}$ is the only country that has not ratified the Convention on the Conservation of Migratory Species of Wild Animals (CMS). All other global multilateral treaties have been ratified by all SEE countries. With regard to ratification of European-level multilateral treaties, the status varies from country to country, as can be seen in Table 4.

The list provided in Table 4 is not exhaustive and additional treaties of interest are noted in the national reports in Chapter 3. 
Table 4 Multilateral treaties relevant for nature conservation ratified in SEE by 2017

\begin{tabular}{|c|c|c|c|c|c|c|c|c|}
\hline International treaty & $\begin{array}{l}\text { Under the } \\
\text { auspices }\end{array}$ & Albania & ВiH & Croatia & Macedonia & Montenegro & Serbia & Slovenia \\
\hline $\begin{array}{l}\text { Convention on Wetlands of International } \\
\text { Importance, Especially as Waterfowl } \\
\text { Habitat (Ramsar Convention), } 1971\end{array}$ & $\begin{array}{l}\text { Ramsar } \\
\text { Secretariat }\end{array}$ & $\bullet$ & - & $\bullet$ & $\bullet$ & $\bullet$ & $\bullet$ & $\bullet$ \\
\hline $\begin{array}{l}\text { Convention on Protection of the World } \\
\text { Natural and Cultural Heritage (World } \\
\text { Heritage Convention), } 1972\end{array}$ & UNESCO & $\bullet$ & $\bullet$ & $\bullet$ & $\bullet$ & $\bullet$ & - & $\bullet$ \\
\hline $\begin{array}{l}\text { Convention on International Trade in } \\
\text { Endangered Species of Wild Flora and } \\
\text { Fauna (CITES), } 1973\end{array}$ & UNEP & - & $\bullet$ & $\bullet$ & $\bullet$ & $\bullet$ & $\bullet$ & $\bullet$ \\
\hline $\begin{array}{l}\text { Convention for the Protection of the } \\
\text { Marine Environment and the Coastal } \\
\text { Region of the Mediterranean (Barcelona } \\
\text { Convention), } 1976\end{array}$ & UNEP & $\bullet$ & $\bullet$ & $\bullet$ & & $\bullet$ & & $\bullet$ \\
\hline $\begin{array}{l}\text { Convention on the Conservation of } \\
\text { Migratory Species of Wild Animals (CMS), } \\
1979\end{array}$ & UNEP & $\bullet$ & $\bullet$ & $\bullet$ & $\bullet$ & $\bullet$ & $\bullet$ & $\bullet$ \\
\hline $\begin{array}{l}\text { Convention on the Conservation of } \\
\text { European Wildlife and Natural Habitats } \\
\text { (Bern Convention), } 1979\end{array}$ & $\begin{array}{l}\text { Council of } \\
\text { Europe }\end{array}$ & $\bullet$ & $\bullet$ & $\bullet$ & $\bullet$ & $\bullet$ & • & $\bullet$ \\
\hline $\begin{array}{l}\text { Agreement on the Conservation } \\
\text { of Populations of European Bats } \\
\text { (EUROBATS), } 1991\end{array}$ & UNEP & $\bullet$ & & $\bullet$ & $\bullet$ & $\bullet$ & 1 & $\bullet$ \\
\hline $\begin{array}{l}\text { Convention on Biological Diversity (CBD), } \\
1992\end{array}$ & UN & $\bullet$ & $\bullet$ & $\bullet$ & $\bullet$ & • & - & $\bullet$ \\
\hline $\begin{array}{l}\text { United Nations Framework Convention on } \\
\text { Climate Change (UNFCCC), } 1992\end{array}$ & UN & $\bullet$ & $\bullet$ & $\bullet$ & $\bullet$ & $\bullet$ & $\bullet$ & $\bullet$ \\
\hline $\begin{array}{l}\text { Convention on the Protection and Use } \\
\text { of Transboundary Watercourses and } \\
\text { International Lakes, } 1992\end{array}$ & UNECE & $\bullet$ & $\bullet$ & $\bullet$ & $\bullet$ & & $\bullet$ & $\bullet$ \\
\hline $\begin{array}{l}\text { United Nations Convention to Combat } \\
\text { Desertification (UNCCD), } 1994\end{array}$ & UN & $\bullet$ & - & $\bullet$ & $\bullet$ & $\bullet$ & $\bullet$ & $\bullet$ \\
\hline $\begin{array}{l}\text { Convention on Cooperation for the } \\
\text { Protection and Sustainable Use of the } \\
\text { Danube River, } 1994\end{array}$ & $\begin{array}{l}\text { International } \\
\text { Commission for } \\
\text { the Protection of } \\
\text { the Danube River }\end{array}$ & & $\bullet$ & $\bullet$ & & $\bullet$ & $\bullet$ & $\bullet$ \\
\hline $\begin{array}{l}\text { Agreement on the Conservation of African- } \\
\text { Eurasian Migratory Waterbirds (AEWA), } \\
1995\end{array}$ & UNEP & $\bullet$ & & $\bullet$ & $\bullet$ & $\bullet$ & 2 & $\bullet$ \\
\hline $\begin{array}{l}\text { Protocol Concerning Specially Protected } \\
\text { Areas and Biological Diversity in the } \\
\text { Mediterranean (SPA/BD Protocol), } 1995\end{array}$ & UNEP & • & & $\bullet$ & & $\bullet$ & & $\bullet$ \\
\hline $\begin{array}{l}\text { Agreement on the Conservation } \\
\text { of Cetaceans in the Black Sea, } \\
\text { Mediterranean Sea and Contiguous } \\
\text { Atlantic Area (ACCOBAMS), } 1996\end{array}$ & UNEP & $\bullet$ & & $\bullet$ & & $\bullet$ & & $\bullet$ \\
\hline $\begin{array}{l}\text { Convention on Access to Information, } \\
\text { Public Participation in Decision-making } \\
\text { and Access to Justice in Environmental } \\
\text { Matters (Aarhus Convention), } 1998\end{array}$ & UNECE & $\bullet$ & • & $\bullet$ & $\bullet$ & $\bullet$ & $\bullet$ & $\bullet$ \\
\hline $\begin{array}{l}\text { Cartagena Protocol on Biosafety to the } \\
\text { CBD, } 2000\end{array}$ & UN & $\bullet$ & • & $\bullet$ & $\bullet$ & $\bullet$ & $\bullet$ & $\bullet$ \\
\hline European Landscape Convention, 2000 & $\begin{array}{l}\text { Council of } \\
\text { Europe }\end{array}$ & & $\bullet$ & $\bullet$ & $\bullet$ & $\bullet$ & $\bullet$ & • \\
\hline
\end{tabular}

${ }^{1}$ In the process of preparation for ratification; ${ }^{2}$ Prepared for ratification

Source: ECOLEX (www.ecoloex.org); National reports 


\section{Alignment of national biodiversity strategies with global and EU strategies}

The national reports describe the status of each country's NBSAP and their alignment with the global CBD Strategic Plan for Biodiversity 2011-2020 and the EU Biodiversity Strategy to 2020.

CBD is the key convention that guides nature conservation at the global level. The revised and updated Strategic Plan for Biodiversity for the period 2011-2020 was adopted at the tenth meeting of the Conference of the Parties (COP) to the CBD in Nagoya, Japan, in 2010. The Strategic Plan, including 20 Aichi Biodiversity Targets, is a guiding global framework on biodiversity, organized under five strategic goals:

1. Address the underlying causes of biodiversity loss by mainstreaming biodiversity across government and society

2. Reduce the direct pressures on biodiversity and promote sustainable use

3. Improve the status of biodiversity by safeguarding ecosystems, species and genetic diversity

4. Enhance the benefits to all from biodiversity and ecosystem services

5. Enhance implementation through participatory planning, knowledge management and capacity-building (UNEP/CBD COP 10, 2010).

Parties to the CBD agreed to translate this global framework into their NBSAPs by setting their own targets based on the national priorities and needs within two years from adoption of the CBD Strategic Plan.

In 2011, the European Commission adopted a new EU Biodiversity Strategy to 2020 to halt the loss of biodiversity and ecosystem services at the European level. The EU Strategy is fully aligned with the CBD Strategic Plan for Biodiversity 2011-2020. It comprises six main targets, namely:

1. Fully implement the Birds and Habitats Directives

2. Maintain and restore ecosystems and their services

3. Increase the contribution of agriculture and forestry to maintaining and enhancing biodiversity

4. Ensure the sustainable use of fisheries resources

5. Combat invasive alien species

6. Help avert global biodiversity loss (European Commission, 2011).

The situation regarding the alignment of NBSAPs in the SEE countries with the global and the EU guiding strategic framework is not entirely satisfactory, as most countries have not fully translated the global and the EU goals into their NBSAPs. The timing of NBSAP adoption in each country (except Albania) and the period they cover provides an explanation to this gap (see Table 5). Evidently, all SEE countries have developed NBSAPs, though the years of adoption were mainly either prior to or at the time of adoption of the CBD and/or the EU strategies. The same applies to the Sustainable Development Goals (SDGs) adopted in September 2015.

The most recent development is visible in Albania where a new NBSAP covering the period from 2014-2020 and fully complying with global and the EU directions was approved in 2016. Similarly, in Montenegro, the new NBSAP covers the period from 2016-2020. The authorities from all other countries reported progress in the revision of their currently effective NBSAPs, claiming future alignment with global and the EU guiding frameworks. For example, Macedonia's NBSAP covered the period from 2004-2008, however, it was reported that a new document was drafted in 2016 and awaiting approval.

Table 5 Adopted National Biodiversity Strategy and Action Plans in the SEE countries

\begin{tabular}{|l|c|c|}
\hline Country & Adoption year & Period covered by the latest NBSAP \\
\hline Albania & 2016 & $2014-2020$ \\
\hline BiH & 2017 & $2015-2020$ \\
\hline Croatia & 2008 & $2008-2012$ \\
\hline Macedonia & 2004 & $2004-2008$ \\
\hline Montenegro & 2016 & $2016-2020$ \\
\hline Serbia & 2011 & $2011-2018$ \\
\hline Slovenia & 2001 & $2002-2012$ \\
\hline
\end{tabular}

Source: National reports 
Although not directly focused on biodiversity as the CBD Strategic Plan for Biodiversity 2011-2020 and the EU Biodiversity Strategy to 2020, the UN Framework Convention on Climate Change (UNFCCC) is an important instrument for directing the global sustainability of biodiversity. In 2016, the Paris Agreement, building upon the UNFCCC, entered into force, with the goal to strengthen global efforts in combating climate change. All SEE countries have signed the Paris Agreement and submitted Nationally Determined Contributions (NDCs) to reduce emissions.

\subsection{Protected areas}

IUCN defines a protected area as:

'a clearly defined geographical space, recognized, dedicated and managed, through legal or other effective means, to achieve the long-term conservation of nature with associated ecosystem services and cultural values' (Dudley, 2008).

This Chapter provides a regional synthesis of the following issues related to protected areas: coverage of protected areas, application of IUCN protected area management categories, management planning, governance and management of protected areas, international recognition of protected areas, and transboundary conservation. Other important aspects related to protected areas and nature conservation in general, such as threats, ecological networks, conservation of species, valuation of ecosystems services, availability of data, financing, and capacity development and needs, are discussed in separate chapters.

\subsubsection{Protected area coverage}

According to the data provided in the national reports, terrestrial protected areas in the SEE region cover $25,156.52 \mathrm{~km}^{2}$, or approximately $8.8 \%$ of the region's land territory (see Table 6). Compared to the global coverage of $15.4 \%$ for terrestrial protected areas (UNEP-WCMC, 2014), the SEE region is falling significantly behind.

The situation is even more alarming in relation to marine protected areas which cover $751.59 \mathrm{~km}^{2}$, totalling about $1.8 \%$ of the SEE region's marine area under national jurisdiction. Compared to the $8.4 \%$ of the global coverage of marine protected areas (UNEP-WCMC, 2014), it is obvious that marine protected areas are a critical gap in the SEE region. Naturally, this data relates only to countries with sea area, i.e. Albania, Croatia, Montenegro and Slovenia (the surface of BiH's marine area is very small and thus excluded from calculation). While Albania, Croatia and Slovenia have designated marine protected areas covering about $2 \%$ of marine areas in Albania and Croatia and nearly 1\% in Slovenia, Montenegro still has no designated marine protected areas.

\section{Table 6 Coverage of protected areas in the SEE countries}

\begin{tabular}{|c|c|c|c|c|c|c|c|c|c|}
\hline $\begin{array}{c}\text { Protected area } \\
\text { coverage }\end{array}$ & Albania & $\mathrm{BiH}$ & Croatia & Macedonia & Montenegro & Serbia & Slovenia & $\begin{array}{c}\text { Total / } \\
\text { km² }^{2}\end{array}$ & $\begin{array}{c}\text { Total / } \\
\%\end{array}$ \\
\hline $\begin{array}{c}\text { Terrestrial } \\
\text { protected areas } \\
/ \mathrm{km}^{2}\end{array}$ & 4,643.04 & $1,062.81$ & $6,914.22$ & $2,300.83$ & $1,721.12$ & $5,787.05$ & $2,727.45$ & $25,156.52$ & 8.8 \\
\hline $\begin{array}{c}\text { Marine protected } \\
\text { areas } / \mathrm{km}^{2}\end{array}$ & 132.61 & 0 & 617.62 & $\begin{array}{r}\text { Not } \\
\text { applicable }\end{array}$ & 0 & $\begin{array}{r}\text { Not } \\
\text { applicable }\end{array}$ & 1.36 & 751.59 & 1.8 \\
\hline Total / km² & $4,775.65$ & $1,062.81$ & $7,531.84$ & $2,300.83$ & $1,721.12$ & $5,787.05$ & $2,728.81$ & $25,908.11$ & \\
\hline Total / \%* & 16.6 & 2.07 & 8.55 & 8.97 & 12.46 & 6.54 & 13.43 & & \\
\hline
\end{tabular}

*The methodology for calculation of total percentage is not the same for all countries, as explained in the text of this Chapter Source: National reports

Figure 1A shows the coverage of protected areas in each SEE country in percentages, as reported by the authorities in all countries. Evidently, the differences between countries vary significantly, from 16.6\% protected area coverage in Albania, to only $2.07 \%$ in $\mathrm{BiH}$. However, it is essential to emphasize that the methodology for calculation of the national total protected area coverage is not uniform in all countries, and thus the percentages presented in Figure 1 and Table 6 should be taken with caution. This is particularly important for countries with a marine area. The following text and Table 7 explain the methodology of calculation of the total percentage of protected areas in the SEE countries with marine areas, while Figure $1 \mathrm{~B}$ provides comparable data. 
Montenegrin and Slovenian total protected area coverage was calculated as the ratio of terrestrial protected areas and land territory, which resulted in protected area coverage of $12.46 \%$ and $13.43 \%$, respectively. It should be noted though that these are actually the data on total terrestrial protected areas in these two countries. However, as Slovenia's marine protected area surface is very small and is neglected in the overall calculation, the total coverage can be considered relatively accurate. This is not the situation with Montenegro, as described below.

The percentage of protected area coverage in Croatia (8.55\%) was calculated by dividing the total surface of protected areas with the sum of the country's land and marine territory. Thus, Croatia's $8.55 \%$ coverage is not comparable to Montenegro's $12.46 \%$ or Slovenia's $13.43 \%$, as they represent entirely different data. If the methodology was harmonized and the total terrestrial protected areas divided by the total land area of Croatia, the percentage for total terrestrial protected areas would be about $12 \%$, which is comparable to the data of Montenegro and Slovenia. Similarly, by applying the methodology used in Croatia to calculate the total coverage of protected areas, the percentage of Slovenia's protected areas is still about 13\%, while the percentage of Montenegro's total protected areas is actually about 10\%. Both of these percentages are directly comparable to Croatia's $8.55 \%$.

In Albania, the methodology used to calculate total protected area coverage in percentage is entirely different. The total surface of protected areas was divided only by the land area, without consideration of the significantly large sea area. Again, by applying the same methodology to make the data comparable, Albania's terrestrial protected area coverage is about $16 \%$, while the total protected area coverage (including terrestrial and marine protected areas) is about $13 \%$.

Taking this harmonized methodology into account, the protected area coverage is equal to or above the regional average (nearly 8\%) in five countries, i.e. Albania, Croatia, Macedonia, Montenegro and Slovenia. Only in BiH and Serbia is the protected area coverage lower than the regional average. By considering only the average regional coverage of terrestrial protected areas (8.8\%), four countries well exceed the average: Albania (16.15\%), Slovenia (13.43\%), Montenegro (12.46\%) and Croatia (12.16\%). Macedonia is about average (8.97\%), while Serbia (6.54\%) and $\mathrm{BiH}(2.07 \%)$ have below average coverage.

Table 7 Methodology for calculating protected area coverage

\begin{tabular}{|c|c|c|c|c|c|}
\hline Country & \begin{tabular}{|l} 
Differing \\
methodology
\end{tabular} & $\begin{array}{c}\text { Reported total } \\
\text { protected } \\
\text { areas / \% }\end{array}$ & Harmonized methodology & $\begin{array}{c}\text { Approximate } \\
\text { TOTAL } \\
\text { protected } \\
\text { areas } / \%\end{array}$ & $\begin{array}{l}\text { Approximate } \\
\text { terrestrial } \\
\text { protected } \\
\text { areas / \% }\end{array}$ \\
\hline \multirow[t]{2}{*}{ Albania } & \multirow{2}{*}{$\begin{array}{l}\text { Total protected areas / land } \\
\text { area }\end{array}$} & \multirow[t]{2}{*}{16.6} & Total protected areas / country's entire area & 13.66 & \\
\hline & & & Terrestrial protected areas / land area & & 16.15 \\
\hline \multirow[t]{2}{*}{ Croatia } & \multirow{2}{*}{$\begin{array}{l}\text { Total protected areas / } \\
\text { country's entire area }\end{array}$} & \multirow[t]{2}{*}{8.55} & Total protected areas / country's entire area & 8.55 & \\
\hline & & & Terrestrial protected areas / land area & & 12.16 \\
\hline \multirow[t]{2}{*}{ Montenegro } & \multirow{2}{*}{$\begin{array}{l}\text { Terrestrial protected areas / } \\
\text { land area }\end{array}$} & \multirow[t]{2}{*}{12.46} & Total protected areas / country's entire area & 10.57 & \\
\hline & & & Terrestrial protected areas / land area & & 12.46 \\
\hline \multirow[t]{2}{*}{ Slovenia } & \multirow{2}{*}{$\begin{array}{l}\text { Terrestrial protected areas / } \\
\text { land area }\end{array}$} & \multirow[t]{2}{*}{13.43} & Total protected areas / country's entire area & 13.31 & \\
\hline & & & Terrestrial protected areas / land area & & 13.43 \\
\hline
\end{tabular}
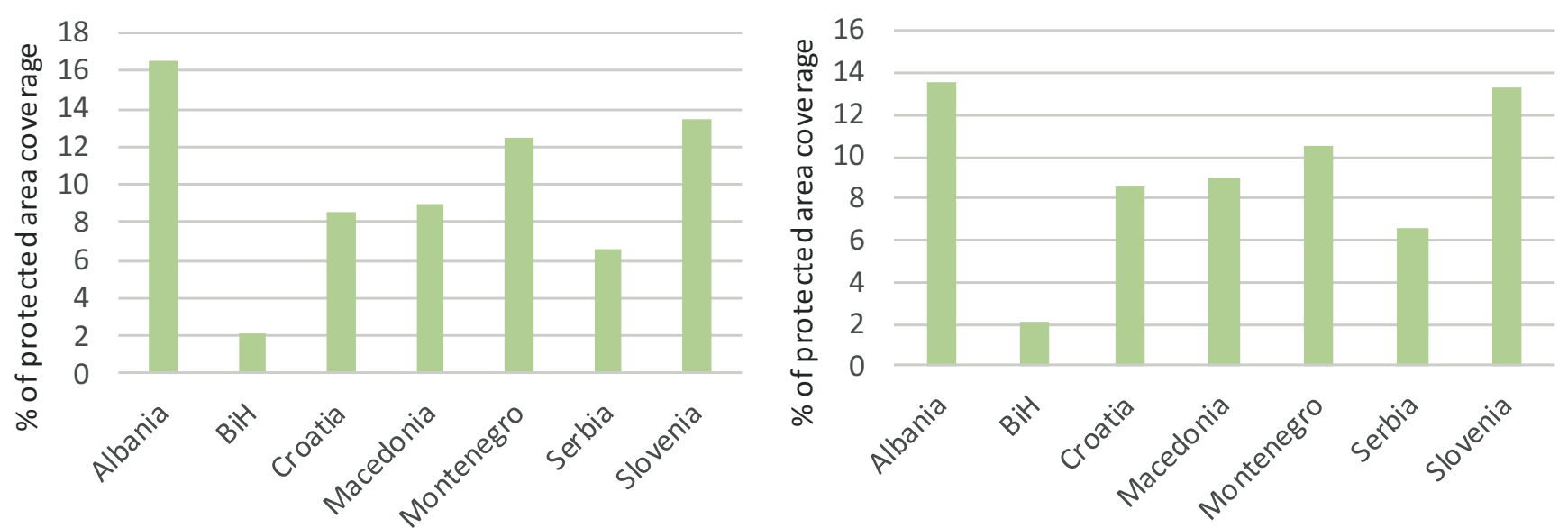

Figure 1 Protected area coverage in SEE countries as reported by countries (A) and with harmonized methodology (B) 


\subsubsection{Application of IUCN protected area management categories in the region}

IUCN protected area management categories provide a global standard for planning, establishment and management of protected areas, protected area systems and wider ecoregions (Dudley, 2008). Additionally, the categories may help in regulating activities in protected areas; i.e. suggesting certain activities in some categories according to a management objective of the protected area. The list and brief description of the IUCN protected area management categories is provided in Table 8.

\section{Table 8 IUCN protected area management categories}

\begin{tabular}{|c|c|}
\hline IUCN management category & Description \\
\hline la Strict nature reserve & $\begin{array}{l}\text { Strictly protected for biodiversity and also possibly geological/ geomorphological } \\
\text { features, where human visitation, use and impacts are controlled and limited to } \\
\text { ensure protection of the conservation values. }\end{array}$ \\
\hline Ib Wilderness area & $\begin{array}{l}\text { Usually large unmodified or slightly modified areas, retaining their natural character } \\
\text { and influence, without permanent or significant human habitation, protected and } \\
\text { managed to preserve their natural condition. }\end{array}$ \\
\hline II National park & $\begin{array}{l}\text { Large natural or near-natural areas protecting large-scale ecological processes } \\
\text { with characteristic species and ecosystems, which also have environmentally } \\
\text { and culturally compatible spiritual, scientific, educational, recreational and visitor } \\
\text { opportunities. }\end{array}$ \\
\hline III Natural monument or feature & $\begin{array}{l}\text { Areas set aside to protect a specific natural monument, which can be a landform, } \\
\text { sea mount, marine cavern, geological feature such as a cave, or a living feature such } \\
\text { as an ancient grove. }\end{array}$ \\
\hline IV Habitat/species management area & $\begin{array}{l}\text { Areas to protect particular species or habitats, where management reflects this } \\
\text { priority. Many will need regular, active interventions to meet the needs of particular } \\
\text { species or habitats, but this is not a requirement of the category. }\end{array}$ \\
\hline V Protected landscape or seascape & $\begin{array}{l}\text { Where the interaction of people and nature over time has produced a distinct } \\
\text { character with significant ecological, biological, cultural and scenic value: and where } \\
\text { safeguarding the integrity of this interaction is vital to protecting and sustaining the } \\
\text { area and its associated nature conservation and other values. }\end{array}$ \\
\hline $\begin{array}{l}\text { VI Protected areas with sustainable } \\
\text { use of natural resources }\end{array}$ & $\begin{array}{l}\text { Areas, which conserve ecosystems, together with, associated cultural values and } \\
\text { traditional natural resource management systems. Generally large, mainly in a } \\
\text { natural condition, with a proportion under sustainable natural resource management } \\
\text { and where low-level non-industrial natural resource use compatible with nature } \\
\text { conservation is seen as one of the main aims. }\end{array}$ \\
\hline
\end{tabular}

Source: Dudley (2008)

All national reports, except those from Serbia, noted that the IUCN protected area management categories have been allocated to protected areas within the countries' national categorisation system. Although the names of the categories need not comply with the names of the IUCN categories (instead, the most suitable management system should be identified and applied) (Dudley, 2008), in some national category systems, names of the categories largely match with the names of IUCN categories, e.g. Albania, Federation of $\mathrm{BiH}$ and the Republic of Srpska entities in $\mathrm{BiH}$, Macedonia and Serbia. The national reports of these countries, with the exception of Serbia, state that the IUCN protected area management categories have been allocated to the protected areas in these countries. In Croatia and Slovenia, IUCN management categories have been unofficially assigned to most protected areas within their national categorisation systems, though it has been recognized that some protected areas are not managed in accordance to the assigned category. Montenegro and Serbia have not yet allocated IUCN categories to their national categorisation systems.

Table 9 was generated with the attempt to estimate the surface of protected areas under each IUCN management category, as per information provided in the national reports. Although precise figures cannot be generated for Slovenia and relevant information is not yet available in Serbia, by taking the data from other countries into regard, it can be concluded that the largest surface of protected areas in SEE is under IUCN management category $\mathrm{V}$. This category allows for continuous human interaction in the landscape. The country with the largest surface under category $V$ is Croatia $\left(6,124.41 \mathrm{~km}^{2}\right)$. The second most widely applied protected area management category in SEE is category II, and the largest surface designated under this category is in Albania $\left(2,105.01 \mathrm{~km}^{2}\right)$ (Figure 2). Nevertheless, this data should be taken with great caution as it is very likely that many protected areas in all SEE observed countries, although claimed to be managed according to 
the guidelines of specific IUCN protected area management categories, are in fact not managed in accordance with the indicated category. The least represented categories in the region are $\mathrm{lb}$, la and $\mathrm{Vl}^{7}$.

Table 9 Surface under IUCN protected area management categories in the SEE countries

\begin{tabular}{|c|c|c|c|c|c|c|c|}
\hline \multirow{2}{*}{$\begin{array}{c}\text { IUCN } \\
\text { category }\end{array}$} & \multicolumn{7}{|c|}{ Area with assigned IUCN protected area management category $/ \mathrm{km}^{2}$} \\
\hline & Albania & $\mathrm{BiH}$ & Croatia & Macedonia & Montenegro & Serbia & Slovenia \\
\hline la & 48 & 5.92 & 24.25 & 77.87 & 4.20 & * & 2 \\
\hline lb & None assigned & 13.93 & None assigned & None assigned & None assigned & & None assigned \\
\hline$\|$ & $2,105.01$ & 397.6 & 966.65 & $1,148.7$ & 1004.27 & & $1,269.741$ \\
\hline III & 34.7 & 511.61 & 1.18 & 789.67 & 147.53 & & 198.41 \\
\hline IV & $1,271.8$ & None assigned & 398.3 & 30.45 & None assigned & & $54.75^{2}$ \\
\hline V & 958.64 & 86.61 & $6,124.41$ & 1.08 & 513.59 & & 1 \\
\hline $\mathrm{Vl}$ & 182.45 & 0.27 & None assigned & 253.05 & None assigned & & None assigned \\
\hline
\end{tabular}

${ }^{*} \mathrm{U} \cup \mathrm{N}$ categories not assigned to national category systems.

'Surface of categories II and V presented jointly in the national report of Slovenia

2Surface of categories I and IV presented jointly in the national report of Slovenia

Source: National reports

The chart below represents the overall surface of protected areas assigned with IUCN protected area management category in the SEE region.

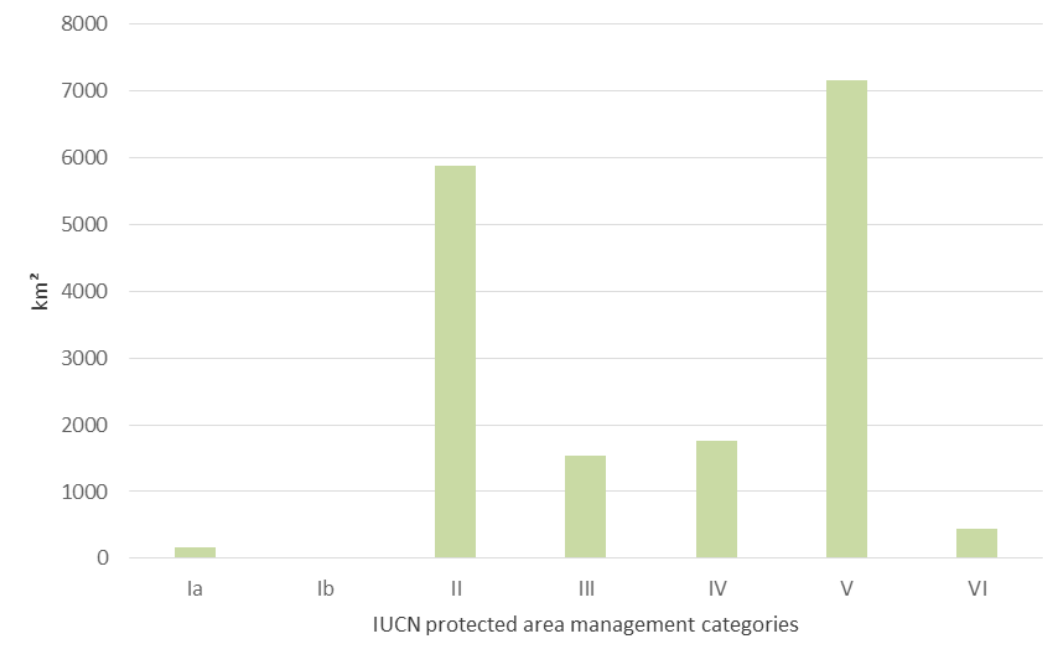

Figure 2 Overall surface of protected areas assigned with IUCN protected area management category in the SEE region Source: National reports

\subsubsection{Protected area management planning}

Developing a management plan for a protected area can be a more or less complex process. A management plan should set out the objectives of the protected area, risks in pursuing these objectives, the management approach and the decisionmaking framework over a certain period of time (Thomas and Middleton, 2003). The final product is a dynamic document, as management needs to be reviewed and the plan adjusted based on lessons learned. The management plan is a very useful tool for protected area managers, serving as guidance and ensuring more effective management.

In the SEE region, all countries are required by their legislation to prepare management plans for some of their protected areas. Moreover, the legal provisions in all countries guide the process of management planning to ensure the involvement of a wide variety of actors at different levels (Stanciu and lonita, 2013). Unfortunately, the national reports did not contain sufficient and comprehensive information on the level of actual implementation of adopted management plans in protected areas, management

7 At the European scale, the most represented IUCN management category is IV, followed by V and II (European Environment Agency, 2012). 
effectiveness, or the on-the-ground situations regarding the participatory approach in preparing the management plans. Therefore, the regional synthesis in this Chapter focuses only on the number of adopted management plans in each country.

National park (in all countries referred to as IUCN protected area management category II) is the most common category in the national protected area systems in the SEE region requiring the preparation of a management plan. There are 40 national parks in the region, with management plans prepared for 27 of them. In only three countries (BiH, Montenegro and Slovenia), management plans have been developed for all of the national parks (Figure 3). In contrast, there are currently no effective management plans for any of the five national parks in Serbia, however they have all been drafted and are in various stages of adoption.

By looking at protected areas other than national parks, Table 10 shows that all countries have developed and adopted management plans for some of their protected areas. The number of management plans varies from country to country. Generally, the highest number of protected area management plans is in Serbia (59), followed by Croatia (16), Albania (14), and $\mathrm{BiH}(10)$. In the remaining three countries, fewer than ten management plans have been adopted for protected areas other than national parks. Considering that some countries have hundreds of designated protected areas, the number of existing management plans is not satisfactory.

A number of countries have new management plans in the process of adoption or development: Macedonia (6), Serbia (5), Croatia (4), Albania (2), and $\mathrm{BiH}(1)$.

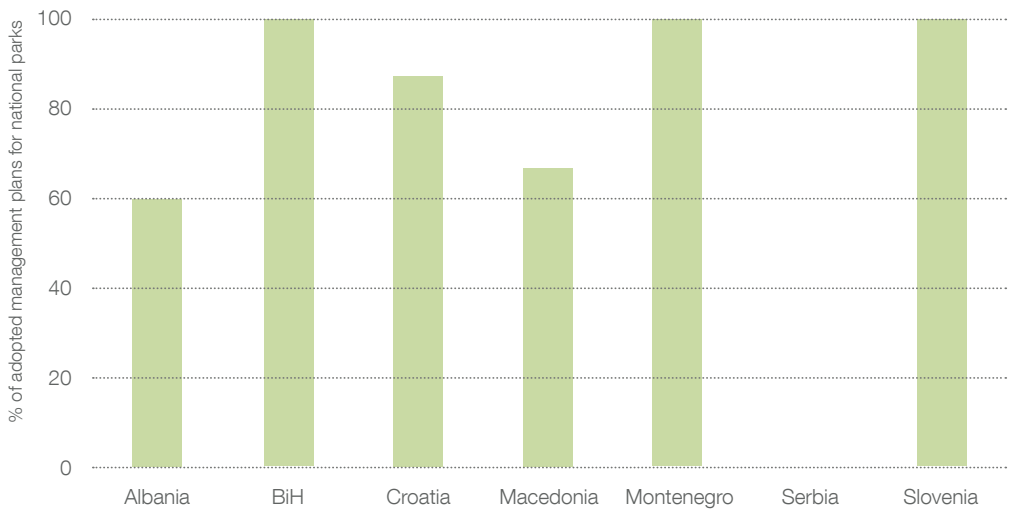

Figure 3 Percentage of existing management plans for national parks in the SEE countries

Source: National reports

Table 10 Adopted protected area management plans in the SEE countries

\begin{tabular}{|l|c|c|c|c|c|c|c|}
\hline Management plan/Country & Albania & BiH & Croatia & Macedonia & Montenegro & Serbia & Slovenia \\
\hline Management plans for national parks & 9 & 3 & 7 & 2 & 5 & 0 & 1 \\
\hline Management plans for other protected areas & 5 & 7 & 9 & 1 & 1 & 59 & 3 \\
\hline Total of adopted management plans & 14 & 10 & 16 & 3 & 6 & 59 & 4 \\
\hline
\end{tabular}

Source: National reports

\subsubsection{Protected area governance and management}

Governance of protected areas refers to the process of decision-making and the exercise of authority and responsibility for the main decisions that affect the site. It is defined as:

'the interactions among structures, processes and traditions that determine how power and responsibilities are exercised, how decisions are taken, and how citizens or other stakeholders have their say' (Graham et al., 2003). 
Governance and management always complement each other through iterative processes; governance informing management and experience in management influencing governance. The following explanation provides key differences between governance and management.

Governance is about process:

- Who decides what the objectives are

- How the decisions are taken

- Who brings relevant people together to determine what should happen

- Who holds the power, authority and responsibility

- Who is accountable

- Who and how ensures the resources and conditions for effective implementation of decisions (Borrini-Feyerabend et al., 2013; Vasilijević et al., 2015).

Management is about substance:

- What is done in the pursuit of given objectives

- The means and actions to achieve objectives (Borrini-Feyerabend et al., 2013).

According to IUCN, there are four types of governance of protected areas (Borrini-Feyerabend et al., 2013), each with its own set of characteristics and sub-types (Table 11).

\section{Table 11 IUCN governance types of protected areas}

\begin{tabular}{|l|l|}
\hline Governance type & Sub-types \\
\hline $\begin{array}{l}\text { Type A. Governance by } \\
\text { government }\end{array}$ & $\begin{array}{l}\text { - Federal or national ministry or agency in charge } \\
\text { - Sub-national ministry or agency in charge (e.g., at regional, provincial, municipal level) } \\
\text { - Government-delegated management (e.g., to an NGO) }\end{array}$ \\
\hline $\begin{array}{l}\text { Type B. Shared } \\
\text { governance }\end{array}$ & $\begin{array}{l}\text { - Transboundary governance (formal and informal arrangements between one or more countries) } \\
\text { - Collaborative governance (through various ways in which diverse actors and institutions work } \\
\text { together) } \\
\text { - Joint governance (pluralist board or other multy-party governing body) }\end{array}$ \\
\hline $\begin{array}{l}\text { Type C. Private } \\
\text { governance }\end{array}$ & $\begin{array}{l}\text { Conserved areas established and run by: } \\
\text { - individual landowners } \\
\text { - for-profit organisations (e.g., corporate landowners) }\end{array}$ \\
\hline $\begin{array}{l}\text { Type D. Governance by } \\
\text { indigenous peoples and } \\
\text { local communities }\end{array}$ & $\begin{array}{l}\text { Indigenous peoples' conserved territories and areas - established and run by indigenous } \\
\text { Peoples }\end{array}$ \\
\hline
\end{tabular}

Source: Borrini-Feyerabend et al. (2013)

The concept of governance is usually unclear and generally not very well understood in the SEE region, which might be the reason why most of the national reports either did not attempt to describe protected area governance at all, or discussed it very limitedly. Considering this, the following section is based on the information provided in the national reports to a limited extent, and largely on the information provided by Stanciu and lonita (2013) .

SEE countries largely and predominantly practice governance by government (IUCN Type A), characterized by limited involvement and consultation with stakeholders in decision-making (Table 12). The most centralized form of this type of governance is when the overall responsibility and accountability for management of protected areas is with the national ministry responsible for nature conservation. Although this is the predominant form of governance in SEE countries as the responsible ministries have the last say in approving management plans and programmes for protected areas, most countries have established special state agencies directly reporting to the relevant ministry. These agencies can be established at the national, regional or local levels and decision-making power is decentralized to a larger or lesser extent. For example, in Albania, the Regional Administration of Protected Areas is responsible for management of protected areas and reports to the National Agency of Protected Areas. In Croatia, national public institutions are responsible for the management of national and nature parks, while in Montenegro, the Public Enterprise for National Parks of Montenegro

8 This is the most current explanation of transboundary governance, published in Vasilijević et al. (2015).

9 Note that Stanciu and lonita (2013) contains limited information on protected area governance in BiH, Macedonia and Montenegro due to the general geographic scope of the publication. 
develops management plans for parks which are then approved by government. At the regional level, one can note the example of Croatia's county public institutions that are in charge of the vast majority of protected areas other than national parks and nature parks. At the local level, local public institutions manage several interesting tourism sites.

The laws in all countries provide for government-delegated management of protected areas. Management is usually either delegated to NGOs or to private entities such as private companies. For example, in Croatia, management of the Gajna Significant Landscape is entrusted to an NGO. In Gajna, the NGO and the County Council govern the area collaboratively, and therefore, this case is also a potential example of shared governance (IUCN Type B). In Slovenia, management of two protected areas has been government-delegated to both public and private entities. These are: Sečovlje Salina Landscape Park, managed by a private company, with decision-making shared between the private company and the Ministry of the Environment and Spatial Planning, Škocjanski Zatok Nature Reserve and Logarska Dolina Landscape Park, managed by an NGO. Another example of government-delegated management is found in Serbia's Zasavica Special Nature Reserve, where management is delegated to an NGO. In Macedonia, the government delegated the management of several protected areas to local municipalities, some of which further delegated the management to NGOs. In Montenegro, management of two protected areas was delegated to private companies. With regards to $\mathrm{BiH}$, there is insufficient information provided to assess the situation regarding 'de facto' delegated management.

Shared governance (IUCN Type B), in particular collaborative and transboundary sub-types, is enabled in Albania, Croatia, Macedonia and Slovenia. A form of collaborative governance can be found in Albania, Croatia and Slovenia, where two or more stakeholders have a decision-making role. For example, Lonjsko Polje Nature Park in Croatia established two committees (the Cooperation Committee at the protected area level and the Posavina Committee at regional level) to guide decision-making jointly with the Protected Area Board. This is a good example of stakeholder involvement in decisionmaking on the management of protected areas, although not required by Croatian legislation.

A form of transboundary governance has been noted in Albania and Macedonia, and relates to the Prespa Lakes, shared between Albania, Greece, and Macedonia. Transboundary conservation governance includes variations of formal and informal arrangements between stakeholders from two or more countries. ${ }^{10}$ The three countries established the Prespa Park Coordination Committee in 2000, a non-binding body consisting of representatives of the ministries of environment, local municipalities, NGOs and MedWet/Ramsar that oversees the management and activities in the Prespa Lake ecosystem.

Private governance (IUCN Type C) is not evident in any SEE country. Moreover, it is usually the type of protected area governance that is least practiced in the whole of Europe, with the exception of some countries such as the United Kingdom.

Governance by local communities (IUCN Type D) is not practiced widely, although there is one example reported in the Slovenian national report where the Logarska Dolina Landscape Park is managed by a public institution consisting of the municipality and a company established by local people.

The above overview shows that there is very limited diversity in protected area governance in the SEE region, with the predominant type being governance by government. There is a need to raise awareness in all SEE countries about the importance of good and diverse governance for the success of protected areas, and to provide a legal framework that would support diverse actors to take responsibility of decision-making in protected area management. As shown in this overview, although central governments usually have a decision-making role, de facto management of protected areas can be undertaken by diverse actors, such as local municipalities, NGOs, private companies, public institutions consisting of various actors and providing for shared governance.

\section{Protected area management effectiveness}

The IUCN Protected Area Management Effectiveness Framework (Hockings et al., 2006) is a widely used framework for assessing protected area management effectiveness. Two methodologies in particular, developed following the IUCN Framework, have been applied in the SEE region. One is the Management Effectiveness Tracking Tool (METT), developed by WWF and the World Bank (Stolton et al., 2007), and applied for assessing protected area management effectiveness in Albania and Croatia. In Albania, two assessments were done, one within UNDP's project 'Protecting Albania's Marine and Coastal Biodiversity' (2011-2016). ${ }^{11}$ An online platform was created and handed over to the Albanian National Agency

10 For more insight on transboundary conservation governance, see Vasilijević et al. (2015).

11 More information is available at:

http://www.al.undp.org/content/albania/en/home/operations/projects/environment_and_energy/protecting-albania-s-marine-and-coastal-biodiversity.html 
of Protected Areas with the intention to use it as a regular monitoring tool. The second METT assessment in Albania was performed by IUCN within the EU funded project 'Strengthening national capacity in nature protection - preparation for Natura 2000 network' (Avramoski et al., 2016). At the site level, METT was applied for the transboundary Shkodra/Skadar Lake in Albania in 2015 and in Montenegro in 2016.

Another methodology based on IUCN's Framework is the Rapid Assessment and Prioritization of Protected Area Management (RAPPAM), developed by WWF (Ervin, 2003). RAPPAM was implemented in 2009 by WWF in all observed SEE countries, except Macedonia, as part of the 'Dinaric Arc Ecoregion' project (2007-2012); in Albania (Porej and Diku, 2009), BiH (Porej and Matić, 2009), Croatia (Porej and Rajković, 2009), Montenegro (Porej and Stanišić, 2009), Serbia (Porej, Piščević, Orlović-Lovren, 2009), and Slovenia (Kus Veenvliet and Sovinc, 2009).

Findings in these countries are invaluable for informing managers of how well protected areas are being managed, tackling various aspects of protected area management.

\section{Table 12 IUCN governance types of protected areas in the SEE countries}

\begin{tabular}{|c|c|c|c|c|c|c|c|c|c|c|c|}
\hline \multirow[b]{2}{*}{ Country } & \multicolumn{3}{|c|}{$\begin{array}{l}\text { Type A. Governance by } \\
\text { government }\end{array}$} & \multicolumn{3}{|c|}{$\begin{array}{l}\text { Type B. Shared } \\
\text { governance }\end{array}$} & \multicolumn{3}{|c|}{ Type C. Private governance } & \multicolumn{2}{|c|}{$\begin{array}{c}\text { Type D. } \\
\text { Governance } \\
\text { by Indigenous } \\
\text { Peoples and local } \\
\text { communities }\end{array}$} \\
\hline & 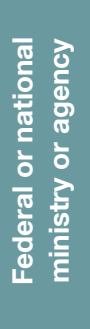 & 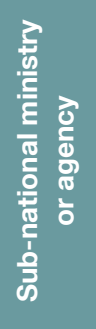 & 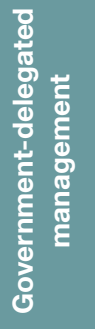 & 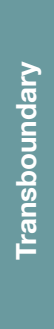 & $\begin{array}{l}\frac{9}{1} \\
\frac{0}{0} \\
\frac{8}{10} \\
\frac{0}{0}\end{array}$ & 䓂 & 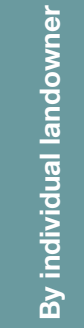 & 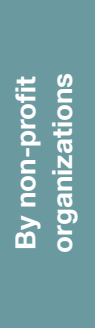 & 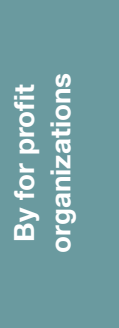 & 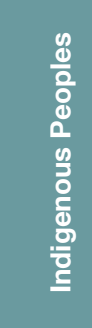 & 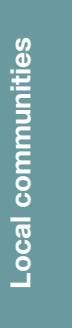 \\
\hline Albania & - & $\bullet$ & $\bullet$ & $\bullet$ & • & & & & & & \\
\hline $\mathrm{BiH}$ & $\bullet$ & • & $\bullet$ & & & & & & & & \\
\hline Croatia & $\bullet$ & $\bullet$ & $\bullet$ & & $\bullet$ & & & & & & \\
\hline Macedonia & $\bullet$ & & $\bullet$ & $\bullet$ & & & & & & & \\
\hline Montenegro & • & • & - & & & & & & & & \\
\hline Serbia & - & • & $\bullet$ & & & & & & & & \\
\hline Slovenia & $\bullet$ & $\bullet$ & $\bullet$ & & $\bullet$ & & & & & & $\bullet$ \\
\hline
\end{tabular}

Source: Adapted from Stanciu and lonita (2013) and National reports

\subsubsection{International recognition of protected areas}

International designations of protected areas were designed to accomplish a national commitment to an international convention or a programme signed by the relevant country. Becoming part of the international 'community' of protected areas can be a big achievement for a country, and is sometimes an issue of prestige, but certainly a recognition of the exceptional values for which a particular site was designated. In the following assessment, the focus is on four international conventions or programmes under which protected areas are designated. Three of these have been implemented under the umbrella of the UNESCO and one under the Ramsar Secretariat (see Table 13). 
Table 13 International conventions and programmes recognising protected area values in the SEE region

\begin{tabular}{|l|l|l|c|}
\hline International convention/programme & Adoption & Site designation & $\begin{array}{c}\text { Designated sites } \\
\text { in the SEE region }\end{array}$ \\
\hline $\begin{array}{l}\text { The Convention on Wetlands of International } \\
\text { Importance, Especially as Waterfowl Habitat } \\
\text { (Ramsar Convention) }\end{array}$ & Ramsar, 1971 & $\begin{array}{l}\text { Wetland of International Importance } \\
\text { (Ramsar Site) }\end{array}$ & 29 \\
\hline $\begin{array}{l}\text { The Convention Concerning the Protection } \\
\text { of the World Cultural and Natural Heritage } \\
\text { (UNESCO World Heritage Convention) }\end{array}$ & Paris, 1972 & World Heritage Site & 4 \\
\hline $\begin{array}{l}\text { UNESCO Man and the Biosphere (MAB) } \\
\text { Programme }\end{array}$ & 1971 & Biosphere Reserve & 9 \\
\hline $\begin{array}{l}\text { International Geoscience and Geoparks } \\
\text { Programme (under the auspices of UNESCO) }\end{array}$ & 2015 & UNESCO Global Geoparks & 3 \\
\hline \begin{tabular}{l} 
Source: National reports \\
\hline
\end{tabular}
\end{tabular}

Table 13 shows that three relevant international conventions and/or programmes were adopted in the early 1970s, while the newest addition to the international designations came recently in 2015 . Each of these designations has its own niche. UNESCO World Heritage Sites promote the conservation of natural and cultural sites of outstanding universal value, Biosphere Reserves encourage harmonised management of biodiversity and sustainable use, Ramsar Sites promote conservation and wise use of wetlands, while UNESCO Global Geoparks protect geological heritage through local community support.

In the SEE region, there are 44 protected areas recognized through the international conventions and/or programmes (Table 13), and the locations are shown in Figure 4.

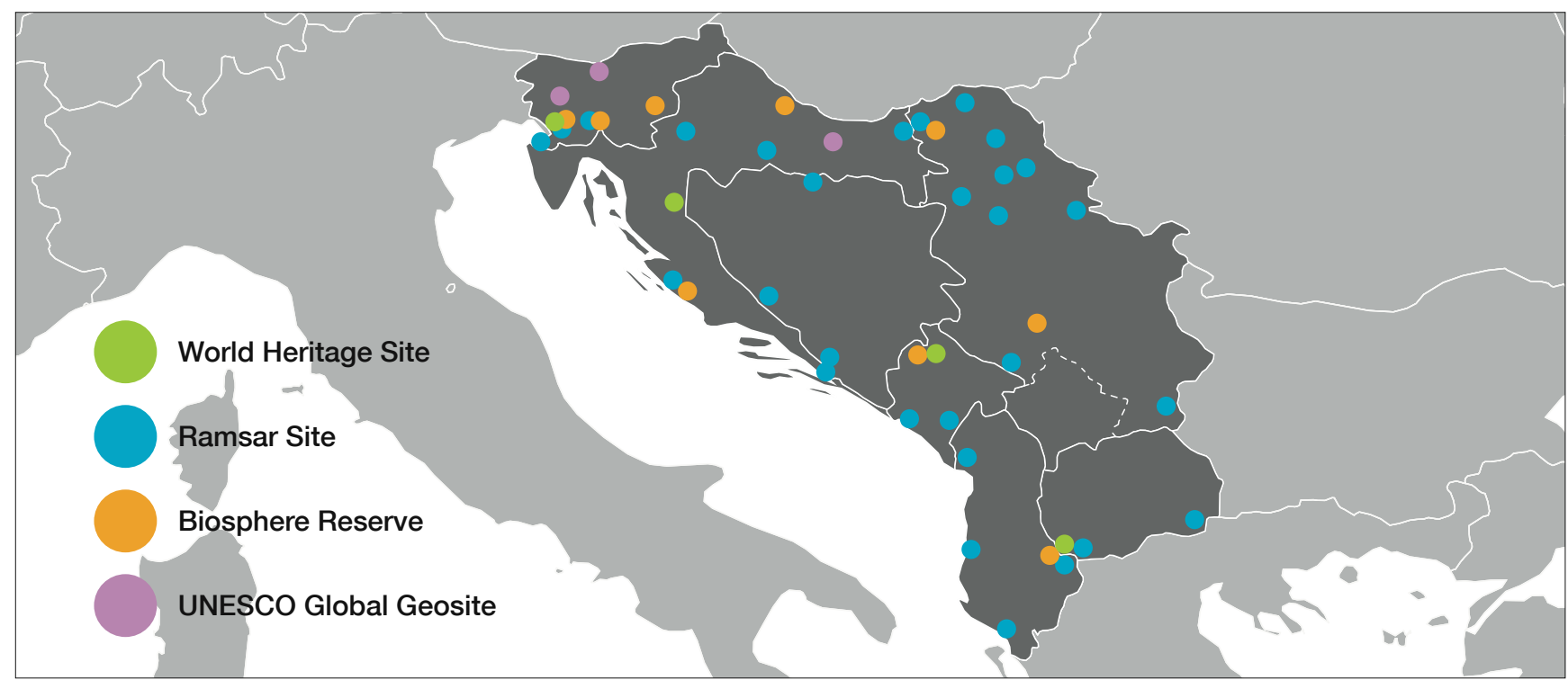

\section{Figure 4 Internationally recognized sites in SEE}

The highest number of internationally designated sites falls under the Ramsar Site designation (29), and this is the only international designation found in all the SEE countries (Figure 5). The highest number of Ramsar Sites is in Serbia (10), followed by Croatia (5), Albania (4), BiH (3), Slovenia (3), Macedonia (2) and Montenegro (2). The second most widespread international designation in the SEE is Biosphere Reserve. The region hosts eight Biosphere Reserves, three in Slovenia, two in Croatia and Serbia, and one in Montenegro, while Albania and Macedonia share a Transboundary Biosphere Reserve.

The region is home to four World Heritage Sites, three of which are designated for their natural values and one for a combination of natural and cultural values. The World Heritage Sites are located in Croatia, Macedonia, Montenegro and Slovenia. The youngest international designation, UNESCO Global Geopark, has been designated to three sites in the SEE region, two in Slovenia and one in Croatia.

According to the number of international designations per country, the highest number of internationally recognized sites is in Serbia (11), ten of which fall under the category of Ramsar Site. Croatia and Slovenia have the second highest number 
of international designations, nine each, while the lowest number of international designations are in BiH and Montenegro (three each). All four international designations can be found only in Croatia and Slovenia. On the other hand, all of the sites designated in $\mathrm{BiH}$ fall under one international designation (Figure 5).

12

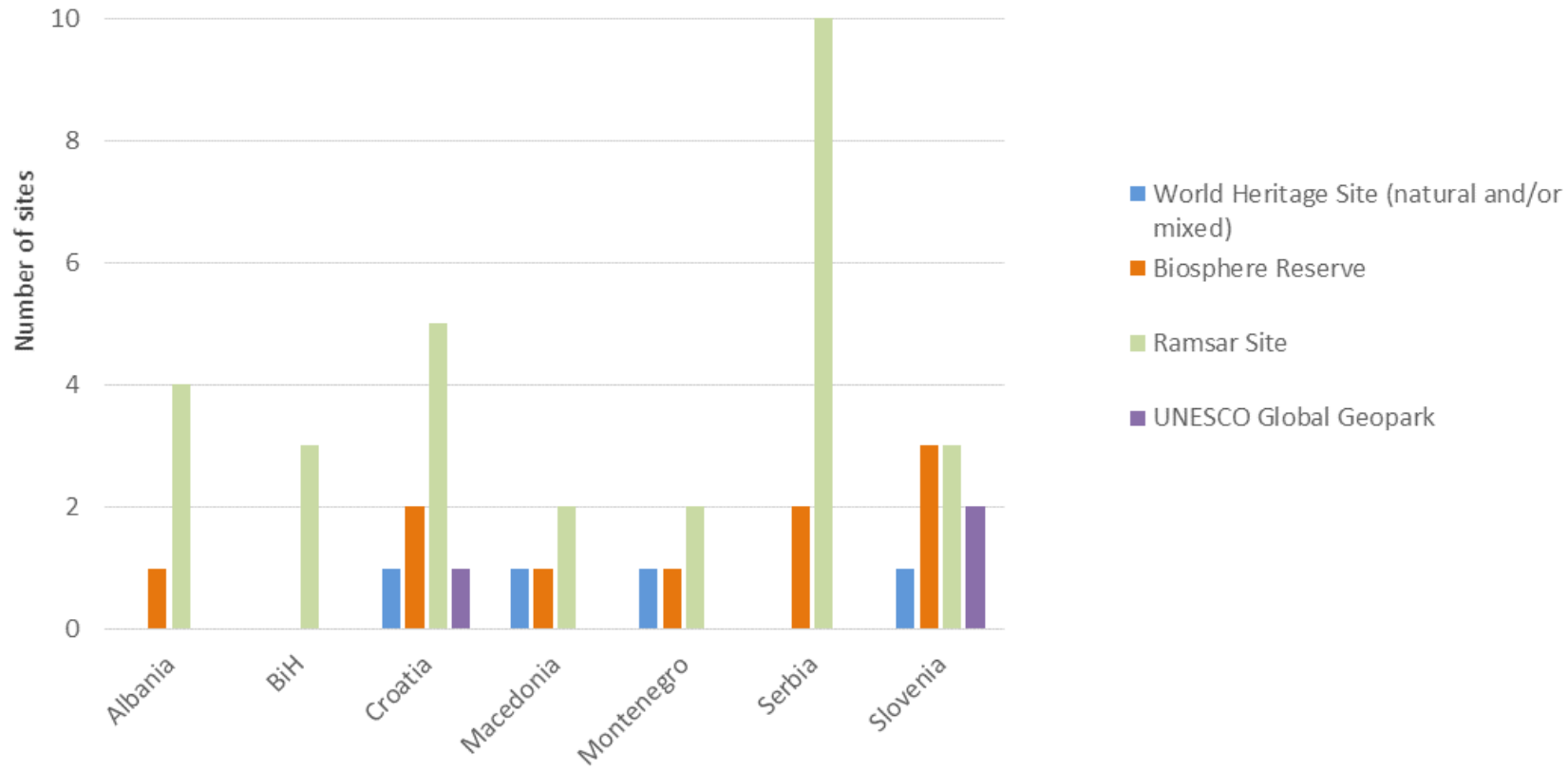

Figure 5 Internationally recognized sites in the SEE region by country

Source: National reports

\subsubsection{Transboundary conservation}

Transboundary conservation is a 'process of cooperation to achieve conservation goals across one or more international boundaries' (Vasilijević et al., 2015). Although this IUCN's definition may seem simple, transboundary conservation is far from simple and usually involves complex negotiations between parties from two or more countries aiming to cooperate in conservation of a particular ecologically connected area. Transboundary conservation is usually a lengthy process requiring substantial financial means, administrative work, political commitment and above all, the dedication and goodwill of all interested parties. Reaching a shared vision and developing a framework for cooperative management is critical for the sustainability of a transboundary conservation initiative. In a region such as SEE, part of which experienced armed conflict while some areas still endure political tensions, establishing a shared vision and ultimately a Transboundary Conservation Area ${ }^{12}$ can be a challenging task.

The SEE region consists of many small countries and thus divided by political boundaries that intersect valuable ecosystems and habitats. Transboundary cooperation as a process that would enable integrated regional planning and action is one of the prerequisites for implementation of common priorities in conservation. The benefits of transboundary conservation can be manifold, including ecological, social, economic, cultural, political, and day-to-day protected area management.

In SEE, there are a number of ongoing transboundary initiatives and site-based initiatives intended to strengthen transboundary cooperation and to potentially establish new Transboundary Conservation Areas in the region.

For example, the transboundary Shkodra/Skadar Lake Conservation Programme, focusing on cooperation between two Ramsar Sites, Lake Shkodra and Buna River in Albania and Skadar Lake in Montenegro, is an important programme which has strengthened cooperation between the two neighbouring countries in the conservation of the lake ecosystem and sustainable use of natural resources.

Another example of transboundary conservation of wetlands includes cooperation between Albania, Greece and Macedonia in the Prespa Lakes. Three Ramsar Sites, Albanian Prespa Lakes (Albania), Lake Prespa (Macedonia), and Lake Mikri Prespa

12 For IUCN definitions of types of Transboundary Conservation Areas, see IUCN WCPA Best Practice Protected Areas Guidelines No. 23 (Vasilijević et al., 2015). 
(Greece) form a trilateral Transboundary Conservation Area. The Prespa Park Coordination Committee was established in 2000 following the signing of a trilateral Joint Declaration between the Macedonian, Albanian and Greek Prime Ministers. The Committee oversees activities in the trilateral Prespa Lakes ecosystem. The cooperation was further strengthened in 2017, when the ministries of the environment of the three countries and the EU signed a historic Agreement on the Protection and Sustainable Development of the Prespa Park Area. Prespa is also part of the 4,500 km² Ohrid-Prespa Transboundary Biosphere Reserve (declared in 2014) shared between Macedonia and Albania. In 2017, the Fund for Nature of Prespa-Ohrid is expected to start operating with the goal to fund projects that aim to protect biodiversity and strengthen management of protected areas in the region of Prespa-Ohrid.

In terms of internationally designated sites that are also Transboundary Conservation Areas, apart from Ohrid-Prespa, the region hosts another Transboundary Biosphere Reserve, Mura Drava Danube, shared by Croatia and Hungary and declared in 2012. There is also one transnational UNESCO Global Geopark, Karawanken-Karavanke (Austria/Slovenia), designated in 2015. None of the World Heritage Sites are transboundary, although there is the potential for strengthened transboundary cooperation between Durmitor National Park in Montenegro and Sutjeska National Park in BiH, and Plitvice Lakes National Park in Croatia and Una National Park in BiH. In fact, the first focused efforts for establishing transboundary cooperation between the Plitvice Lakes and Una national parks were made during the implementation of the EU Community Assistance for Reconstruction, Development and Stabilisation (CARDS) project 'Promoting conservation of border river ecosystems and sustainable use of resources in the border area of Croatia and $\mathrm{BiH}^{\prime}$ in 2004. The cooperation between the two parks is primarily focused on sustainable tourism development.

In $\mathrm{BiH}$ and Croatia, several initiatives and projects have been implemented in the Neretva Delta to promote the mechanisms and opportunities for establishing transboundary collaboration. For example, the then Ministry of Environmental Protection, Physical Planning and Construction (Croatia), together with the then Ministry of Environmental Protection, Physical Planning and Construction (Herzegovina-Neretva Canton in $\mathrm{BiH}$ ) implemented the project 'Transboundary management plan for the lower Neretva Valley' in 2001-2002 through the Ramsar Small Grants Fund. This project created an inventory database of the natural values of the Neretva Delta, tested the Mediterranean Wetlands Initiative's database tool and involved local communities in the process of wetland evaluation, planning and decision making. The establishment of the joint Neretva Delta Forum, as a result of the efforts of the Regional Environmental Centre, with the aim to serve as a cross-border communication and coordination platform, is considered as one of the most important achievements in establishing a permanent platform for transboundary collaboration in this region.

Transboundary conservation efforts are also evident in the initiative for the establishment of Tara-Drina Biosphere Reserve (BiH/ Serbia). Tara National Park (Serbia) and the Republic Institute for the Protection of Cultural, Historical and Natural Heritage (Republic of Srpska, BiH) signed a Memorandum of Understanding to improve cooperation in the fields of cultural, historical and nature conservation. A long-term plan for this area is to submit a joint application for Biosphere Reserve recognition encompassing the Tara and Drina National Parks.

A Memorandum of Understanding between the Faculty of Science of the University of Sarajevo in BiH and the then State Institute for Nature Protection in Croatia, provides a general framework for cooperation and participation in research, monitoring and restoration of wetlands and ornithofauna in Livanjsko Polje and for the subterranean fauna of Dinara Mountain, and creates a basis for transboundary cooperation in these areas.

The transboundary conservation programme in Prokletije-Bjeshkët e Namuna continues to strengthen cooperation between Montenegro and Albania. Furthermore, there are continuing efforts to establish a Transboundary Protected Area Shar MountainKorab, shared between Albania and Macedonia. In 2013, the Vision for the Transboundary Protected Area Shar MountainKorab was signed by the ministers of environment during the second Trilateral Ministerial Conference. The conference served to improve local partnership and facilitate cross-border contacts and consultations to identify common priorities in the field of nature conservation and local development.

The southernmost boundary of the observed SEE region involves the Albanian boundary with Greece. While transboundary conservation programmes cover extensive areas and important habitats, there is room for improving transboundary cooperation in order to ensure coordinated planning and management with Greece. Important protected areas in Albania adjacent to the Greek boundary are Germenj-Shelegura, Sotira and Butrint, all national parks.

In the north-western part of the region, informal transboundary conservation initiatives are ongoing between Triglav National Park in Slovenia and Prealpi Giuglie Nature Park in Italy, and Goričko-Raab-Őrség (Slovenia/Austria/Hungary). With regards to transboundary cooperation in the protection of large carnivores, Croatia and Slovenia have cooperated in the management of wolf and lynx, while the two countries have ongoing cooperation for brown bear management within the 'DinAlp bear' LIFE+ project. 
Several Natura 2000 sites extend the boundaries of Slovenia, e.g. Drava and Mura Rivers, Kočevsko and Snežiško in the Dinaric Arc, Karst area and the Julian Alps. However, due to various administrative and legal circumstances for the implementation of conservation measures in accordance with Article 6 of the Habitats Directive, these areas do not have unified management ${ }^{13}$ with Natura 2000 sites in the neighbouring countries.

\subsection{Ecological networks}

Fragmentation of habitats caused by the extent and intensity of human activity is one of the key threats to sustain European biodiversity, including that in SEE. Due to the growing awareness that a limited number of separate valuable natural areas was not succeeding in halting the decline in the integrity of protected areas and many species populations, and that human activity in the landscape has been increasing, the ecological network model emerged as a potential solution to these problems. The goal of the ecological network is to maintain or restore the functioning of ecosystems as a means to conserve biodiversity, while providing opportunities for sustainable use of natural resources (Bennet and Wit, 2001). Thus, ecological networks (and also similar models such as ecoregion-based conservation, bioregional planning, biological/conservation corridors, etc.) integrate conservation and sustainable development. The ecological network model consists of core areas, buffer zones, diverse types of corridors, and sustainable use areas (Figure 6).

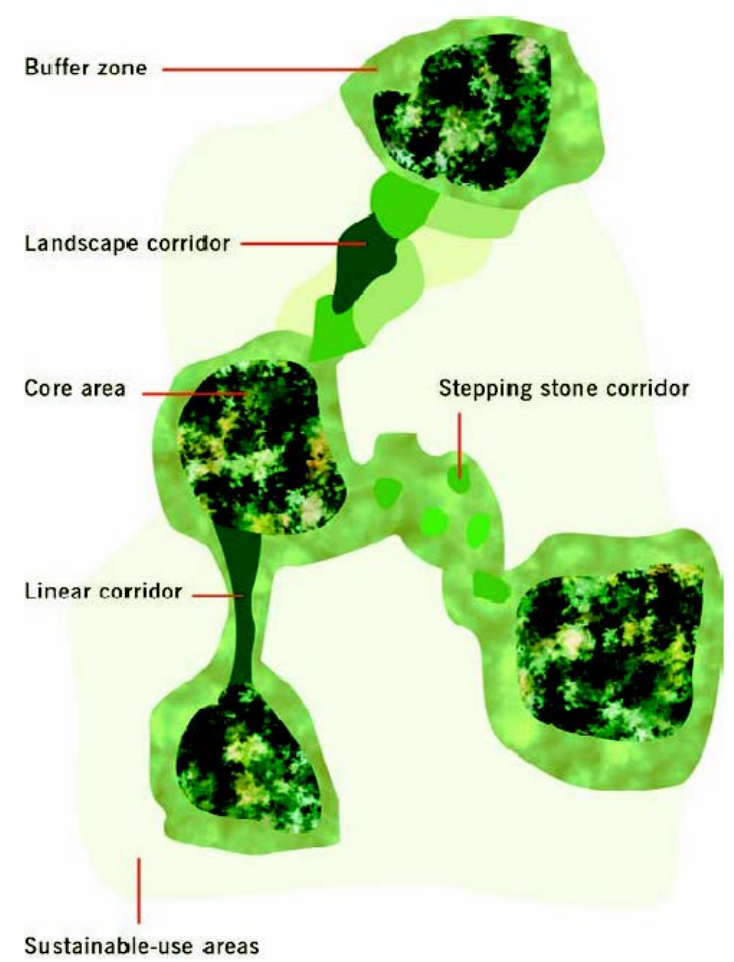

\section{Figure 6 Components of an ecological network}

Source: Bennet (2004)

Ecological networks can be implemented at different geographical scales; local, national, regional, transboundary, and continental. The following sub-chapters provide the synthesis of the status of the most prominent ecological networks applied and/or designed in the SEE countries.

\section{Natura 2000}

Natura $2000^{14}$ is the EU ecological network aimed at securing sustainability of Europe's most valuable and threatened habitats and species. Under the provisions of the EU Birds Directive, Natura 2000 comprises Special Protection Areas (SPAs), while under the EU Habitats Directive it comprises Sites of Community Importance (SCls) and Special Areas of 
Conservation (SACs). Today, the Natura 2000 network encompasses over $18 \%$ of the EU land territory and nearly $6 \%$ of its marine area.

Considering the status of SEE countries with regards to EU accessions (Table 14), progress in applying the Natura 2000 network varies from country to country. Croatia and Slovenia, as EU Member States, designated the Natura 2000 networks in 2013 and 2004 respectively. Both of these countries are at the very top in terms of the percentage of their territories covered by the Natura 2000 network compared to the EU average. While Slovenia's Natura 2000 network covers $37.16 \%$ of the country's surface, in Croatia it covers $29.38 \%$ of the country's territory, including $36.67 \%$ of the land territory and $16.39 \%$ of inland waters and the territorial sea. The area with designated Natura 2000 sites in these two countries covers more than $33,000 \mathrm{~km}^{2}$.

Croatia's Natura 2000 network largely stems from the previously established Croatian National Ecological Network. This network, which comprised important sites for conservation of rare and endangered species and habitat types was designated in 2007, and later replaced by Natura 2000 following the country's accession to the EU.

In the four EU Candidate countries, Albania, Macedonia, Montenegro and Serbia, the progress in identifying potential sites for inclusion into the future Natura 2000 network varies from country to country (Table 14). Albania and Macedonia have started the identification of Natura 2000 sites through EU-funded Instrument for Pre-accession Assistance (IPA) projects. Progress is also evident in Montenegro and Serbia, and in the EU Potential candidate, BiH, all of which have prepared draft reference lists of habitats and species, and work is ongoing to further lay ground for the Natura 2000 network.

\section{Table 14 Status of the Natura 2000 network in the SEE countries}

\begin{tabular}{|c|c|c|}
\hline EU Member status & Country & Natura 2000 status \\
\hline Member & Croatia & $\begin{array}{l}\text { Natura } 2000 \text { network established in } 2013 \text {, comprising } 742 \text { proposed Sites of } \\
\text { Community Importance (of which } 171 \text { sites are speleological structures) and } 38 \text { Special } \\
\text { Protection Areas, i.e. } 36.67 \% \text { of the land territory and } 16.39 \% \text { of inland waters and } \\
\text { territorial sea. } 26.14 \% \text { of Natura } 2000 \text { surface are protected areas. }\end{array}$ \\
\hline Member & Slovenia & $\begin{array}{l}\text { Natura } 2000 \text { network established in 2004, and enlarged in } 2013 \text { and 2016, } \\
\text { encompassing } 31 \text { Special Protection Areas and } 324 \text { Special Areas of Conservation, i.e. } \\
37.16 \% \text { of the country's territory. }\end{array}$ \\
\hline Candidate & Albania & $\begin{array}{l}\text { Implementing IPA } 2013 \text { project to help start the process of identification of Special } \\
\text { Protection Areas and Special Areas of Conservation. }\end{array}$ \\
\hline Candidate & Macedonia & $\begin{array}{l}\text { Implementing IPA Transition Assistance and Institution Building Component (TAIB) } \\
\text { (2016-2017) project to help start the process of identification of Special Protection } \\
\text { Areas and Special Areas of Conservation. }\end{array}$ \\
\hline Candidate & Montenegro & $\begin{array}{l}\text { Draft reference list of habitat types and species and draft catalogue of Natura } 2000 \\
\text { habitats prepared in } 2009 \text {. However, these documents did not enable the start of } \\
\text { identification of Natura } 2000 \text { sites. In 2016, a new IPA project started with the aim to lay } \\
\text { foundation for Natura } 2000 \text {. }\end{array}$ \\
\hline Candidate & Serbia & $\begin{array}{l}\text { Draft reference list of habitat types and species including } 43 \text { Special Protection Areas } \\
\text { developed during the IPA } 2007 \text { twinning project 2010-2012. Implementation of an IPA } \\
2012 \text { project started in } 2015 \text { aimed at identification of further Natura } 2000 \text { sites, but the } \\
\text { project was terminated by the EUD in } 2016 \text {. }\end{array}$ \\
\hline $\begin{array}{l}\text { Potential } \\
\text { candidate }\end{array}$ & $\mathrm{BiH}$ & $\begin{array}{l}\text { Potential Natura } 2000 \text { sites identified, including } 122 \text { areas comprising over } 200 \text { species } \\
\text { and } 60 \text { habitats, i.e. } 18,63 \% \text { of the country. }\end{array}$ \\
\hline
\end{tabular}

Source: National reports

\section{Emerald Network}

The Emerald Network ${ }^{15}$ is an ecological network made up of Areas of Special Conservation Interest. The design and setting up of the Emerald Network was launched by the Council of Europe in 1989 as part of its work under the Convention on the Conservation of European Wildlife and Natural Habitats (Bern Convention), recommending the Parties to the Convention to undertake steps to designate Areas of Special Conservation Interest and ensure relevant conservation measures are taken for these areas (Council of Europe, 2016). If properly implemented and managed, it could be considered an extension of Natura 2000 network to non-EU countries.

15 http://www.coe.int/en/web/bern-convention/emerald-network 
The process of identification of the Emerald Network in all SEE countries (except Slovenia) was guided by successive EU CARDS projects running from 2004-2006 (Phase I) and 2007-2008 (Phase II). Further activities were performed under the EU IPA project from 2010-2011. In Serbia, the ecological network, established in 2010 and comprising 101 areas of ecological importance, included 61 previously identified potential sites of the Emerald Network. All non-EU countries in the observed SEE region have officially submitted their lists of proposed Areas of Special Conservation Interest to the Standing Committee of the Bern Convention for approval (Table 15).

\section{Table 15 Status of the Emerald Network in SEE countries}

\begin{tabular}{|c|l|}
\hline Country & \multicolumn{1}{|c|}{ Emerald Network } \\
\hline Albania & $\begin{array}{l}25 \text { proposed Areas of Special Conservation Interest covering 17.8\% of the country's territory, officially } \\
\text { nominated for inclusion to the Emerald Network. }\end{array}$ \\
\hline BiH & $\begin{array}{l}29 \text { proposed Areas of Special Conservation Interest covering 4.04\% of the territory of the Federation of BiH, } \\
\text { officially nominated for inclusion to the Emerald Network. }\end{array}$ \\
\hline Croatia & Emerald Network outlined. \\
\hline Macedonia & $\begin{array}{l}35 \text { proposed Areas of Special Conservation Interest covering 29\% of the country's territory, officially } \\
\text { nominated for inclusion to the Emerald Network. }\end{array}$ \\
\hline Montenegro & 32 proposed Areas of Special Conservation Interest officially nominated for inclusion to the Emerald Network. \\
\hline Serbia & 61 proposed Areas of Special Conservation Interest officially nominated for inclusion to the Emerald Network. \\
\hline Slovenia & Slovenia did not accede to the Emerald Network activity. \\
\hline Source: National reports
\end{tabular}

\section{Other ecological networks}

Apart from Natura 2000 and Emerald Network which cover a broader geographical scale, three countries in the SEE region have designed and some even established, more or less successfully, other ecological networks at the national level.

In Croatia, the National Ecological Network was officially proclaimed by Regulation in 2007 including a full description of all sites forming part of the ecological network and habitat types and species for which the sites were designated. Another national ecological network in the region that has been officially established is the ecological network of Serbia, proclaimed in 2010. Nevertheless, unlike Croatia, it contains a list of 101 sites without including any description of sites nor target features. In Macedonia, the proposal for the National Ecological Network (MAK-NEN) was developed in 2011, but the ecological network was never officially adopted and is not functional.

\subsection{Regional initiatives}

There are several ongoing regional initiatives that have promoted transboundary and regional cooperation in conservation in recent years; some are briefly described below.

\section{Dinaric Arc Initiative}

The Dinaric Arc (or the Dinarides) hosts important freshwater ecosystems, subterranean rivers and lakes, mountains, large forests, karst habitats, wetlands, coastal and marine habitats, including many endemic plant and animal species and large carnivores. The Dinaric Arc Initiative ${ }^{16}$ is a partnership of World Wide Fund for Nature (WWF), UNESCO Regional Office for Science and Culture in Europe, IUCN, United Nations Development Programme (UNDP), Council of Europe, Food and Agriculture Organization (FAO), UNEP, former Netherlands Development Organisation, Euronatur, International Council for Game and Wildlife Conservation, and Regional Environmental Centre; which have been cooperating and making synergies since 2004 to promote the natural and cultural values of the Dinarides. Though actively pursued for more than ten years, cooperation under the DAI has decreased lately.

16 http://www.dinaricarcinitiative.net/index.htm 


\section{Big Win for Dinaric Arc}

The political boundaries of states in the SEE region intersect ecosystems and important habitats, which requires an integrative approach in conservation planning and management. One of the first initiatives to foster regional agreement of cooperation in nature conservation was the Big Win for Dinaric Arc ${ }^{17}$, facilitated by the Dinaric Arc Initiative partners. This initiative focused specifically on the Dinaride ecoregion of SEE. In 2008, during the $9^{\text {th }}$ CBD Conference of the Parties (COP), the governments of Albania, BiH, Croatia, Montenegro, Serbia and Slovenia signed a Joint statement recognizing that coordinated efforts are needed to efficiently deliver the CBD Programme of Work on Protected Areas, including the creation of a well-managed and ecologically representative protected area network.

The second Joint statement within the Big Win for Dinaric Arc initiative, endorsed in 2013 in Budva, Montenegro, also brought the government of Macedonia in addition to the former signatories of the Statement. The governments agreed to further strengthen their cooperation in nature conservation, including regional conservation planning.

In 2008 and 2013, responsible ministries presented their national priorities in conservation, whose implementation aims to strengthen the delivery of the CBD Strategic Plan for Biodiversity 2011-2020, and of the EU Directives on nature conservation and the EU Biodiversity Strategy to 2020.

\section{Dinaric Arc Parks}

In 2014, a regional association called Parks Dinarides-network of protected areas of Dinarides, was established in Montenegro with the aim to facilitate efficient networking among all protected areas in the Dinarides area. This is the first such association in the SEE. The representatives of 36 protected areas elected the President and the Governing Council of the association. This was made possible due to the WWF project Dinaric Arc Parks, ${ }^{18}$ funded by the Norwegian Ministry of Foreign Affairs and MAVA Foundation, and initiated in 2012. The project aims to create a network of 75 protected areas in the Dinarides region and strengthen their cooperation and dialogue.

\section{European Green Belt}

The European Green Belt ${ }^{19}$ is a pan-European initiative comprising more than 3,200 protected areas located along the former line of the Iron Curtain and promoting the conservation and sustainable development of its natural heritage. It is organized into four sections: Fennoscandian, Baltic, Central European and Balkan. The Balkan Green Belt is the southernmost section. Apart from the remarkable natural values forming the European Green Belt, the initiative brings together nearly 150 different stakeholders, including governments, NGOs, municipalities, protected areas, enterprises and scientific institutions.

\section{Balkan Lynx Recovery Programme}

An important transboundary programme that focused on the recovery of the Critically Endangered Balkan lynx (Lynx lynx balcanicus), whose population has declined dramatically during the past century, was carried out from 2006 to 2009. The Balkan Lynx Recovery Programme, ${ }^{20}$ funded by MAVA Foundation, was implemented by NGOs from the SEE region, Protection and Preservation of Natural Environment in Albania and Macedonian Ecological Society, and international partner NGOs, Swiss KORA and EuroNatur. It was an important initiative that built professional capacity for monitoring of wildlife, and generated support of governments, NGOs and general public for long-term conservation of the lynx in border areas along the Balkan Green Belt of Albania and Macedonia, and Albania and Montenegro.

\section{Open Regional Fund for South-East Europe-Biodiversity}

The Open Regional Fund for South-East Europe-Biodiversity is a project funded by the German Federal Ministry of Economic Cooperation and Development and implemented by German Organization for International Cooperation (GIZ). It aims to

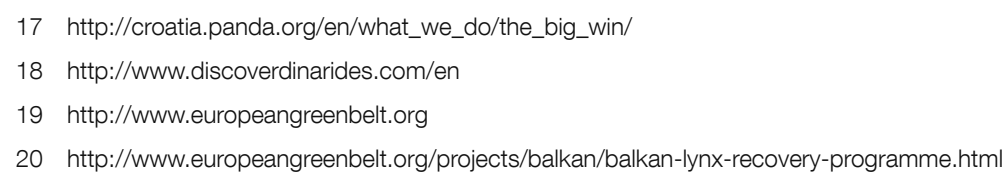


promote regional cooperation between nature conservation institutions in SEE, particularly the ministries and agencies in charge of environment, nature conservation, finance, tourism, and agriculture, the municipal administrations, academic institutions, research institutes, and NGOs, as to implement the EU Biodiversity Strategy to 2020. To achieve the objectives of the project, specific projects in four fields of action are currently being implemented:

- 'Ecosystem Services Assessment and Valuation (ESAV) in Future Course of Action in South-East Europe', that aims to increase the knowledge of government administration at the national and local levels, academia, civil sector and private sector actors in the SEE region regarding the economic value of biodiversity and ecosystem services

- 'Regional Network for Biodiversity Information Management and Reporting (BIMR)', that aims to improve the skills of network partners to monitor and report on biodiversity in line with EU standards and CBD requirements

- 'Transboundary Ecosystem Management', that aims to design and initiate implementation of measures for transboundary management of ecosystems and the protection of priority species in identified transboundary habitats

- 'Regional Network of Biodiversity Related Civil Society Organisations (BioNET)', that aims to strengthen regional cooperation of the qualified biodiversity related civil society organisations in SEE for increased impact at the national and regional levels.

\section{Biodiversity Task Force}

The Biodiversity Task Force (BD TF) was established in 2017 under the auspices of the Regional Cooperation Council (RCC) to advise the Regional Working Group on Environment (RWG Env) on how to mainstream biodiversity concerns in the South East Europe 2020 Strategy. The aim of BD TF is to stimulate regional cooperation and enable progress towards international biodiversity commitments, including the Strategic Plan for Biodiversity 2011-2020, the Aichi Biodiversity Targets and implementation of EU nature directives. The Secretariat of the Biodiversity Task Force is hosted by IUCN ECARO.

\subsection{Conservation of species}

The SEE region is located at the junction of four biogeographic regions: Mediterranean, Alpine, Continental and Pannonian; all having important an effect on the development of fauna and flora. From the European perspective, the SEE is one of the richest regions in biodiversity that also hosts large carnivores: brown bear (Ursus arctos), wolf (Canis lupus) and lynx (Lynx lynx). Its terrestrial and aquatic subterranean fauna is very diverse, with about 1,000 known species of land invertebrates and nearly 700 aquatic species (Kryštufek and Reed, 2004). The region hosts about 380 endemic invertebrate species (Deltshev, 2004). Endemism is a characteristic feature of the ichthyofauna which is also highly threatened, while important endemics can be found among amphibians and reptiles (Freyhof, 2012).

\section{IUCN Red List}

The IUCN List of Threatened Species ${ }^{21}$ assesses the conservation status and distribution of plants, fungi and animals that have been globally evaluated according to the IUCN Red List Categories and Criteria. The categories include: Extinct, Extinct in the Wild, Critically Endangered, Endangered, Vulnerable, Near Threatened, Least Concern, Data Deficient and Not Evaluated. IUCN Red List is the most comprehensive global system for assessing the conservation status of species, relying on scientific knowledge, with over 73,000 species currently being monitored.

The number of the assessments of the conservation status of groups of species in the SEE region varies from country to country (Table 16). Slovenia and Croatia have assessed more than 40 and 20 taxonomic groups respectively, followed by Albania with 17 assessments and noted in the national report that these assessments are incomplete. In Macedonia, three Red Lists have been drafted but have not been officially adopted.

BiH's national report noted problems with monitoring biodiversity, primarily due to the lack of knowledge regarding methodology; however, a number of Red Lists were developed at the entity level, without any attempt to harmonize them at the national level (15 taxonomic group assessments in the Federation of BiH and 7 in the Republic of Srpska). In Montenegro, insufficient financing among other issues seems to have resulted with no Red Lists developed. Generally, monitoring presumes surveillance of changes in the status of certain species and trends for species (or habitats) for which the reference level is already known. In the observed SEE countries, most of the national reports noted the lack of basic reference data on the distribution and status of species and habitats, e.g. in $\mathrm{BiH}$ and Montenegro, thus impeding potential monitoring. Credibility of the performed assessments varies, as for

21 http://www.iucnredlist.org/about/introduction 
example Slovenia's national report indicated that the data in their Red List assessments is largely outdated, the analyses being done mainly in the 1990s. In Serbia, several Red Books have been developed, but no Red Lists have been compiled.

Table 16 Red Lists in the SEE countries

\begin{tabular}{|c|c|c|}
\hline \multicolumn{2}{|r|}{ Country } & Taxonomic groups (animals, plants, fungi) \\
\hline \multicolumn{2}{|r|}{ Albania } & $\begin{array}{l}\text { Vascular plants, sponges, cnidarians, annelids, molluscs, mammals, beetles, butterflies, crustaceans, } \\
\text { insects, echinoderms, birds, reptiles, amphibians, freshwater fish, sea fish, birds }\end{array}$ \\
\hline \multirow{2}{*}{$\mathrm{BiH}$} & $\begin{array}{l}\text { Federation } \\
\text { of } \mathrm{BiH}\end{array}$ & $\begin{array}{l}\text { Fungi, plants, mammals, birds, reptiles, amphibians, crustacean, bony fish, shadflies, dragonflies, } \\
\text { stoneflies, caddisflies, butterflies, beetles, arachnids }\end{array}$ \\
\hline & $\begin{array}{l}\text { Republic of } \\
\text { Srpska }\end{array}$ & Vascular plants, birds, fish species, mammals, amphibians, reptiles, sub-kingdoms of metazoa \\
\hline \multicolumn{2}{|r|}{ Croatia } & $\begin{array}{l}\text { Vascular plants, mammals, freshwater fish, sea anemones, ground beetles, stoneflies, fungi, saltwater } \\
\text { fish, dragonflies, lichens, cave fauna, freshwater crustacean, brackish water crustacean, land snails, } \\
\text { freshwater snails, sea algae, sea grasses, reptiles, amphibians, butterflies, birds }\end{array}$ \\
\hline \multicolumn{2}{|c|}{ Macedonia } & $\begin{array}{l}\text { No officially adopted Red Lists } \\
\text { (3 draft versions: Red Lists of fungi, daily butterflies and Orthoptera) }\end{array}$ \\
\hline \multicolumn{2}{|c|}{ Montenegro } & No Red Lists developed \\
\hline \multicolumn{2}{|r|}{ Serbia } & $\begin{array}{l}\text { No Red Lists developed } \\
\text { (several Red Books have been prepared: plants, butterflies, amphibians, reptiles) }\end{array}$ \\
\hline \multicolumn{2}{|r|}{ Slovenia } & 42 taxonomic groups* \\
\hline
\end{tabular}

${ }^{*}$ No details provided

Source: National reports

\section{Species management and action plans}

All countries in the SEE region have developed several species management or action plans, with the exception of BiH, where no plans have been prepared (Table 17). Action plans are usually relatively short-term documents that provide management measures for certain species. By looking at the list of management or action plans in Table 17, it is unclear if all of them are still effective, considering some were adopted ten or more years ago. Also, the national reports have largely not included the information as to whether the plans have been officially adopted, while it is uncertain how many of these plans have actually been implemented in practice. 
Table 17 Species Management and Action Plans in the SEE countries

\begin{tabular}{|c|c|}
\hline Country & Species Management Plan / Action Plan \\
\hline Albania & $\begin{array}{l}\text { 1. Action Plan for protection of brown bear (Ursus arctos) (2007) } \\
\text { 2. Action Plan for protection of the Eurasian lynx (Lynx lynx) (2007) } \\
\text { 3. Action Plan for protection of Phalacrocorax pygmaeus (2007) } \\
\text { 4. Action Plan for protection of Cetacea (2007) } \\
\text { 5. Action Plan for protection of Posidonia oceanica (2007) } \\
\text { 6. Action Plan for protection of the sea turtle and its natural habitat (2013) }\end{array}$ \\
\hline $\mathrm{BiH}$ & Action Plan for management of ragweed Ambrosia artemisifolia (2008)' \\
\hline Croatia & $\begin{array}{l}\text { 1. Brown bear Management Plan (2008) } \\
\text { 2. Brown bear Action Plan (2014) } \\
\text { 3. Wolf Management Plan with Action Plan (2010-2015) } \\
\text { 4. Lynx Management Plan with Action Plan (2010-2015) } \\
\text { DRAFTS: } \\
\text { 5. Croatian dace Management Plan } \\
\text { 6. Karst meadow viper Management Plan } \\
\text { 7. European otter Management Plan } \\
\text { 8. Saker falcon Management Plan }\end{array}$ \\
\hline Macedonia & $\begin{array}{l}\text { 1. Prespa trout Action Plan (2008) } \\
\text { 2. Brown bear Action Plan (2012) } \\
\text { 3. Mountain tea Action Plan (2012) } \\
\text { 4. Stinking juniper Action Plan (2012) } \\
\text { 5. Prespa barbell Action Plan (2012) } \\
\text { 6. Reed beds Action Plan (2012) } \\
\text { 7. Caves Action Plan, with focus on bats (2012) }\end{array}$ \\
\hline Montenegro & 1. Action Plan for the Dalmatian pelican (2004) \\
\hline Serbia & $\begin{array}{l}\text { 1. Action Plan for wetland protection (2007) } \\
\text { 2. Action Plan for protection and conservation of brown bear (2007) } \\
\text { 3. Action Plan for protection and conservation of wolf (2007) } \\
\text { 4. Action Plan for protection and conservation of lynx (2007) } \\
\text { 5. Action Plan for the management of sturgeon species in fishing waters of the Republic of Serbia (2005) } \\
\text { 6. Action Plan for invasive species (2007) }\end{array}$ \\
\hline Slovenia & $\begin{array}{l}\text { 1. Strategy for management of brown bear (Ursus arctos) (2002) } \\
\text { 2. Strategy for conservation and sustainable management of wolf (Canis lupus) (2009) } \\
\text { 3. Action Plan for management of wolf (Canis lupus) (2013-2017) } \\
\text { 4. Strategy for conservation and sustainable management of lynx (Lynx lynx) (2016-2026) }\end{array}$ \\
\hline
\end{tabular}

Source: National reports; NBSAPs

Management planning for brown bear has been incorporated in the conservation priorities of Albania, Croatia, Macedonia, Serbia and Slovenia. Brown bear, strictly protected according to the EU Habitats Directive, is a protected species in Albania, Croatia, Macedonia and Slovenia, and a strictly protected species in Serbia, although Slovenia and Croatia use derogations under Article 16 of the Habitats Directive to allow a limited cull of bears by hunting. With regards to the implementation of the Action Plan for protection of brown bear in Albania, Kaczensky et al. (2012) note that no concrete action has been seen so far, thus questioning the implementation of management planning actions.

This Chapter briefly examines the situation with the two other large carnivores inhabiting the SEE region: Iynx and wolf. Lynx, strictly protected pursuant to the Habitats Directive, is also strictly protected in all SEE countries except in BiH where it has the status of a game species, yet with permanent protection. Management plans for the lynx have been developed in Albania, Croatia and Serbia, while in Slovenia a strategy has been drafted, but not yet adopted.

Wolf is listed in Annex II of the Habitats Directive as the species of community interest whose conservation requires the designation of special areas; and in Annex IV as the species in need of strict protection. It is strictly protected in Croatia and protected in Slovenia where a limited cull is allowed. In Serbia, wolf is a game species except on a part of the territory of the Vojvodina Province where it is strictly protected. These three countries have management/action plans for the wolf and face challenges with effective protection due to illegal hunting. 
The estimated population of large carnivores in the SEE region is shown in Table 18. The data have been taken from the European Commission's report (Kaczensky et al., 2012) and Chapron et al. (2014), and are based on various sets of sources, including national research and official country data. The timeframe varies from as far as 2007 (status of the population of bear in Slovenia) to 2012 (status of the population of bear in Albania).

Methodology for monitoring of species differs in the region, though there has been a positive development in an increasing number of countries using modern methods for monitoring of all or some of the large carnivore species, e.g. genetic analyses (Croatia, Serbia ${ }^{22}$, Slovenia), camera-trapping (Albania, Croatia, Macedonia, Serbia ${ }^{23}$ ) and satellite telemetry (Croatia) (Kaczensky et al., 2012). Other monitoring methods include questionnaire surveys, systematic counts at feeding sites, snow tracking, collection of dead specimens, consultations with local experts, and extrapolation. Croatia and Slovenia are the most advanced in applying modern monitoring methodology (for all three large carnivores, i.e. brown bear, wolf and lynx), followed by Albania in recent years. In countries like Montenegro and $\mathrm{BiH}$, the exact methodology is either not well known or has never been validated, and it is based on the scarce literature, making it difficult to evaluate and validate the data.

\section{Table 18 Estimated population size of large carnivores in the SEE countries}

\begin{tabular}{|c|c|c|c|c|c|c|c|c|c|c|}
\hline \multirow[b]{2}{*}{ Country } & \multicolumn{4}{|c|}{ Brown bear population } & \multicolumn{4}{|c|}{ Lynx population } & \multicolumn{2}{|c|}{ Wolf population } \\
\hline & Carpathian & $\begin{array}{l}\text { Dinaric- } \\
\text { Pindos }\end{array}$ & Alpine & $\begin{array}{l}\text { Eastern } \\
\text { Balkan }\end{array}$ & Carpathian & Dinaric & Alpine & Balkan & $\begin{array}{l}\text { Dinaric- } \\
\text { Balkan }\end{array}$ & Alpine \\
\hline Albania & & $\begin{array}{r}180-200 \\
\text { (officially } \\
686 \text { ) }\end{array}$ & & & & & & $5-10$ & $\begin{array}{r}200-250 \\
\text { (officially } \\
2,370 \text { ) }\end{array}$ & \\
\hline $\mathrm{BiH}$ & & 550 & & & & 70 & & & 650 & \\
\hline Croatia & & 1,000 & & & & $\sim 50$ & & & $168-219$ & \\
\hline Macedonia & & $160-200$ & & & & & & 23 & 267 & \\
\hline Montenegro & & 270 & & & & & & $\begin{array}{r}\text { N/A (see } \\
1)\end{array}$ & $\mathrm{N} / \mathrm{A}$ & \\
\hline Serbia & 8 & $60 \pm 10$ & & 50 & $50 \pm 10$ & & & $15-25^{1}$ & $800 \pm 50$ & \\
\hline Slovenia & & 440 & $5-10$ & & & $10-15$ & $5-10$ & & $32-43$ & $\begin{array}{r}\text { Occasiona } \\
\text { disperses }\end{array}$ \\
\hline $\begin{array}{l}\text { Approximate } \\
\text { TOTAL }\end{array}$ & & & & $\pm 2,700$ & & & & $\pm \mathbf{2 5 0}$ & & $\pm 2,200$ \\
\hline
\end{tabular}

${ }^{1}$ Data includes Serbia and Montenegro, as per Chapron et al. (2014).

Source: Taken from Kaczensky et al. (2012); Chapron et al. (2014)

The most widespread population of brown bear is the Dinaric-Pindos population that inhabits all SEE countries. According to the IUCN Red List, the Dinaric-Pindos, Eastern Balkan, and Carpathian populations are classified as Vulnerable, while the Alpine population is Critically Endangered. Nevertheless, all countries have a stable or increasing population of brown bear, the largest inhabiting Croatia and the smallest in Serbia.

Four populations of Iynx inhabit the SEE region, Carpathian (found only in Serbia), Dinaric (BiH, Croatia, Slovenia), Alpine (only in Slovenia) and Balkan (Albania, Macedonia, Montenegro, and Serbia). The IUCN Red List assessed the Balkan population as being in the most alarming state (Critically Endangered), Dinaric and Alpine populations as Endangered, and Carpathian as Least Concern. Indeed, the Balkan population of lynx has been decreasing in the region, while the second most widespread population in the region, the Dinaric population, is stable or decreasing.

The populations of wolf in the SEE include the Dinaric-Balkan population that inhabits all SEE countries, and the Alpine population, found only in Slovenia. According to the IUCN Red List, the Dinaric-Balkan population is categorised as Least Concern and Alpine is threatened. Generally, the wolf population has been increasing in SEE.

An important aspect with regards to sustaining large carnivore populations is enabling the transboundary movement of species. However, the mobility and connectivity between populations of certain species is not well researched. Coordinated conservation, research and management actions between countries are essential to ensure sustainability of these populations. For example, there is permanent cooperation between Slovenian and Croatian experts and scientists for the exchange of

22 For monitoring of brown bear only.

23 For monitoring of brown bear and very limitedly for the lynx 
information, monitoring and management measures for wolf (two EU LIFE projects have been implemented, 'CRO-Wolf' and 'SLO-Wolf'). Agreements for the repopulation of lynx and management of brown bear have also been concluded.

In relation to transboundary cooperation in species management, an informal network of institutions, including NGOs from Albania, BiH, Croatia, Macedonia and Serbia, the National Museum of $\mathrm{BiH}$, and the Institute for Nature Conservation of Serbia, has been collaborating with wider regional partners and international institutions in the implementation of the regional Balkan Vulture Action Plan (2002)24.

\subsection{Main pressures}

All countries in the SEE region face similar pressures threatening its biodiversity, some of which are critical also for protected areas. Some of the main groups of pressures are noted in Table 19, and briefly described as follows:

\section{- Accelerated urbanization and transport infrastructure construction}

Extensive and often poorly planned urban development, and construction of the transport network in some SEE countries generates a significant impact on biodiversity in the region. Urbanization along the Adriatic coast and in valuable inland natural areas in some countries threatens sensitive coastal habitats and/or wetland habitats, and this is one of the main causes of habitat fragmentation and destruction, and soil erosion. Urban development is often poorly planned with spatial planning intending to respond to market demands, with little attention to safeguarding nature. Moreover, many countries struggle with illegal construction which often happens in the most sensitive places in terms of natural values. There is a need to control urbanization and related infrastructural development by implementing adequate land use policy, making improvements in spatial planning, and enforcing relevant regulations that would halt illegal construction.

\section{- Uncontrolled development of the energy sector}

Construction of hydropower plants is one of the major threats to rivers in the SEE countries. The issue has not been adequately addressed at the policy level and often there is poor performance or even suppression of the impact assessment procedures in the process of issuing permits. Nature conservation institutions and/or nature conservation regulations are often avoided in planning procedures. Another important threat relates to mining and quarrying (both mineral and non-mineral resource exploitation) that often causes permanent loss of habitats, and thus of the species associated with these habitats.

\section{- Overexploitation of natural resources and poaching}

Excessive and unsustainable extraction of natural resources largely relates to timber, forest products such as medicinal herbs and fungi, and fish. Many countries face challenges with illegal hunting, especially of birds (including migratory birds) and illegal fishing, posing serious threats to fish and bird populations. Apart from a lack of information and knowledge on sustainable use of natural resources, most countries in the region are struggling with the lack of enforcement of hunting and fishing regulations and laws. Freshwater is also one of the natural resources that is in some countries overexploited, e.g. for the purpose of agricultural irrigation and for use in small hydropower plants.

\section{- Excessive alterations of rivers and/or wetlands}

Excessive alteration of rivers and/or wetlands for various purposes is one of the major problems in the SEE region. Such alterations of freshwater ecosystems are often poorly planned and without proper systematic river basin management approach. The main purposes of alteration of rivers and/or wetlands are usually gravel (or sand) extraction and river regulation in order to restrain flooding potential and to reclaim land for construction and agriculture.

\section{- Pollution}

Sources of pollution of water, air and soil vary, including agriculture (pesticides and fertilizers), industry and transport. Generally, the countries face challenges with inadequate infrastructure for the management of communal waste and its disposal, threatening not only freshwater ecosystems, but also marine, forest and other areas. Species in the Adriatic Sea are also exposed to underwater noise pollution due to high number of recreational vessels in coastal zones, especially disturbing dolphins in the summer months, and commercial vessels in the open sea.

\section{- Uncontrolled tourism development}

Tourism in the observed SEE countries has been expanding in the last two decades, though there seems to be a lack of efficient control over tourism development in some countries. Tourism development has been largely intensifying along the Adriatic coast,

$24 \mathrm{http} / / / w w w . b a l k a n v u l t u r e s . n e t$ 
thus affecting Albania, Croatia, Montenegro and Slovenia. Generally, there seems to be orientation towards massive tourism development, resulting in high tourism pressures in the peak summer months. Construction for tourism development purposes and tourism-related activities strongly threatened sensitive coastal habitats such as sand and pebble beaches, sandflats and mudflats that are important habitats for migratory birds. Neptune grass (Posidonia oceanica) meadows that spread along the Adriatic coast, one of the most important and representative Mediterranean coastal ecosystems, are also at risk.

Increased construction of tourism related facilities is not only linked to the Adriatic coast but also some inland attractive areas, including protected areas and their surroundings. Some protected areas have been affected by significant increase in visitor numbers, leaving often under-resourced protected area management teams to deal with occurring and potential tourism-related threats to nature. Although some protected areas have defined guidelines for visitor management, the majority of protected areas either do not have developed guidelines or they lack capacity to implement them.

\section{- Intensive agriculture}

The whole SEE region has been experiencing major changes in agricultural use, with the intensification of agriculture and abandonment of agricultural use as the major trends. Both of these processes have negative consequences on biodiversity. Intensive agriculture alters the use of land and homogenises cultivated surfaces into monoculture production, depleting species and landscape diversity. Abandonment of traditional agricultural activities, such as mowing or grazing, that normally occurred in areas of little economic interest, and over time, these areas become naturally overgrown by forest. Succession impacts the disappearance of species and is also a threat to wetland habitats, which thus require active management.

\section{- Other}

Climate change, invasive species and forest fires are some of the most relevant threats other than those already highlighted earlier. The consequences of climate change are still to be researched. Nevertheless, the expectations include more arid circumstances, higher probabilities for fires, increased erosion, higher temperatures and greater intensity of meteorological disasters.

The noted pressures are augmented by institutional, administrative, and resource and capacity challenges that hinder the proper handling of threats to biodiversity. Relatively low institutional capacity, poor political will, lack of knowledge about different aspects of biodiversity and conservation, low level of implementation and enforcement of national legislation, inadequate implementation of spatial planning documents, and general low priority of the nature conservation sector in the region's political system, all threaten the survival of biodiversity in the region.

Table 19 Main threats to biodiversity in the SEE region

\begin{tabular}{|c|c|c|c|c|c|c|c|}
\hline Threats & Albania & $\mathrm{BHH}$ & Croatia & Macedonia & Montenegro & Serbia & Slovenia \\
\hline $\begin{array}{l}\text { Accelerated } \\
\text { urbanization } \\
\text { and transport } \\
\text { infrastructure } \\
\text { construction }\end{array}$ & $\begin{array}{l}\text { Urbanization } \\
\text { in coastal } \\
\text { areas; illegal } \\
\text { construction; } \\
\text { development } \\
\text { of transport } \\
\text { network }\end{array}$ & $\begin{array}{l}\text { Excessive } \\
\text { construction, } \\
\text { especially in } \\
\text { planned future } \\
\text { protected } \\
\text { areas }\end{array}$ & $\begin{array}{l}\text { Excessive } \\
\text { construction, } \\
\text { especially in } \\
\text { coastal areas }\end{array}$ & $\begin{array}{l}\text { Excessive } \\
\text { construction } \\
\text { and conversion } \\
\text { of land for } \\
\text { construction, } \\
\text { especially in } \\
\text { marsh habitats; } \\
\text { development } \\
\text { of transport } \\
\text { network }\end{array}$ & $\begin{array}{l}\text { Excessive } \\
\text { construction } \\
\text { in coastal and } \\
\text { valuable natural } \\
\text { areas; illegal } \\
\text { construction } \\
\text { in and around } \\
\text { protected areas }\end{array}$ & $\begin{array}{l}\text { Excessive } \\
\text { construction }\end{array}$ & $\begin{array}{l}\text { Excessive } \\
\text { construction, } \\
\text { especially in } \\
\text { coastal areas }\end{array}$ \\
\hline $\begin{array}{l}\text { Uncontrolled } \\
\text { development of } \\
\text { energy sector }\end{array}$ & $\begin{array}{l}\text { Uncontrolled } \\
\text { development } \\
\text { of energy } \\
\text { sector; mining; } \\
\text { construction } \\
\text { of hydropower } \\
\text { plants }\end{array}$ & $\begin{array}{l}\text { Construction } \\
\text { of hydropower } \\
\text { plants; quarries }\end{array}$ & $\begin{array}{l}\text { Regulation of } \\
\text { watercourses }\end{array}$ & $\begin{array}{l}\text { Construction } \\
\text { of hydropower } \\
\text { plants and } \\
\text { energy } \\
\text { transportation } \\
\text { infrastructure; } \\
\text { mining; quarries }\end{array}$ & $\begin{array}{l}\text { Construction } \\
\text { of hydropower } \\
\text { plants }\end{array}$ & $\begin{array}{l}\text { Uncontrolled } \\
\text { development of } \\
\text { energy sector; } \\
\text { construction } \\
\text { of hydropower } \\
\text { plants }\end{array}$ & $\begin{array}{l}\text { Mining; } \\
\text { quarries }\end{array}$ \\
\hline $\begin{array}{l}\text { Overexploitation } \\
\text { of natural } \\
\text { resources and } \\
\text { poaching }\end{array}$ & $\begin{array}{l}\text { Illegal hunting } \\
\text { (especially birds) } \\
\text { and fishing; } \\
\text { excessive } \\
\text { exploitation } \\
\text { of natural } \\
\text { resources } \\
\text { through } \\
\text { commercial } \\
\text { harvesting }\end{array}$ & $\begin{array}{l}\text { Excessive } \\
\text { use of natural } \\
\text { resources, } \\
\text { including } \\
\text { medicinal herbs } \\
\text { and fungi }\end{array}$ & $\begin{array}{l}\text { Excessive } \\
\text { use through } \\
\text { commercial } \\
\text { harvesting } \\
\text { of plants } \\
\text { and fungi, or } \\
\text { through fishing; } \\
\text { poaching }\end{array}$ & $\begin{array}{l}\text { Excessive } \\
\text { logging; illegal } \\
\text { hunting and } \\
\text { fishing }\end{array}$ & $\begin{array}{l}\text { Overexploitation } \\
\text { of forests, rivers } \\
\text { and lakes; } \\
\text { illegal logging; } \\
\text { illegal hunting } \\
\text { (especially birds) } \\
\text { and fishing }\end{array}$ & $\begin{array}{l}\text { Unsustainable } \\
\text { use of natural } \\
\text { resources }\end{array}$ & $\begin{array}{l}\text { Uncontrolled } \\
\text { removal of } \\
\text { plants and } \\
\text { animals }\end{array}$ \\
\hline
\end{tabular}




\begin{tabular}{|c|c|c|c|c|c|c|c|}
\hline Threats & Albania & $\mathrm{BiH}$ & Croatia & Macedonia & Montenegro & Serbia & Slovenia \\
\hline $\begin{array}{l}\text { Excessive } \\
\text { alterations of } \\
\text { rivers and/or } \\
\text { wetlands }\end{array}$ & $\begin{array}{l}\text { Alteration of } \\
\text { water regime }\end{array}$ & & $\begin{array}{l}\text { Alteration of } \\
\text { water regime }\end{array}$ & & $\begin{array}{l}\text { Alteration of } \\
\text { water regime }\end{array}$ & $\begin{array}{l}\text { Alteration of } \\
\text { water regime }\end{array}$ & $\begin{array}{l}\text { Alteration of } \\
\text { water regime }\end{array}$ \\
\hline Pollution & $\begin{array}{l}\text { Pollution of } \\
\text { water }\end{array}$ & $\begin{array}{l}\text { Pollution of } \\
\text { water and air }\end{array}$ & $\begin{array}{l}\text { Pollution of } \\
\text { water, soil and } \\
\text { air }\end{array}$ & $\begin{array}{l}\text { Pollution } \\
\text { of aquatic } \\
\text { ecosystems }\end{array}$ & $\begin{array}{l}\text { Pollution of } \\
\text { freshwater } \\
\text { and marine } \\
\text { ecosystems } \\
\text { coming from } \\
\text { urban and } \\
\text { industrial } \\
\text { sources } \\
\end{array}$ & $\begin{array}{l}\text { Pollution of } \\
\text { water, soil } \\
\text { and air from } \\
\text { industry and } \\
\text { agriculture }\end{array}$ & $\begin{array}{l}\text { Pollution of } \\
\text { surface water, } \\
\text { groundwater } \\
\text { and sea; light } \\
\text { and noise } \\
\text { pollution, } \\
\text { especially in } \\
\text { mountain areas } \\
\end{array}$ \\
\hline $\begin{array}{l}\text { Tourism } \\
\text { development } \\
\text { pressure }\end{array}$ & $\begin{array}{l}\text { Uncontrolled } \\
\text { tourism } \\
\text { development }\end{array}$ & & $\begin{array}{l}\text { Uncontrolled } \\
\text { tourism } \\
\text { development }\end{array}$ & $\begin{array}{l}\text { Uncontrolled } \\
\text { tourism } \\
\text { development }\end{array}$ & $\begin{array}{l}\text { Uncontrolled } \\
\text { tourism } \\
\text { development }\end{array}$ & $\begin{array}{l}\text { Uncontrolled } \\
\text { tourism } \\
\text { development }\end{array}$ & $\begin{array}{l}\text { Uncontrolled } \\
\text { tourism } \\
\text { development }\end{array}$ \\
\hline $\begin{array}{l}\text { Intensive } \\
\text { agriculture }\end{array}$ & $\begin{array}{l}\text { Intensive } \\
\text { agriculture }\end{array}$ & $\begin{array}{l}\text { Conversion of } \\
\text { karst habitats } \\
\text { into agricultural } \\
\text { lands; } \\
\text { excessive use } \\
\text { of pesticides } \\
\text { and fertilizers }\end{array}$ & $\begin{array}{l}\text { Decline in } \\
\text { traditional low- } \\
\text { productivity } \\
\text { agriculture and } \\
\text { abandonment } \\
\text { of previously } \\
\text { large pastures } \\
\text { and meadows } \\
\text { leading to } \\
\text { succession }\end{array}$ & $\begin{array}{l}\text { Decline in } \\
\text { traditional } \\
\text { low-productivity } \\
\text { agriculture and } \\
\text { abandonment } \\
\text { of previously } \\
\text { large pastures } \\
\text { and meadows } \\
\text { leading to } \\
\text { succession }\end{array}$ & $\begin{array}{l}\text { Conversion } \\
\text { of agricultural } \\
\text { lands; } \\
\text { abandonment of } \\
\text { traditional land } \\
\text { use practices } \\
\text { leading to } \\
\text { succession }\end{array}$ & $\begin{array}{l}\text { Intensive } \\
\text { agriculture; } \\
\text { decline in } \\
\text { traditional low- } \\
\text { productivity } \\
\text { agriculture and } \\
\text { abandonment } \\
\text { of previously } \\
\text { large pastures } \\
\text { and meadows } \\
\text { leading to } \\
\text { succession }\end{array}$ & $\begin{array}{l}\text { Intensive } \\
\text { agriculture; } \\
\text { decline in } \\
\text { traditional low- } \\
\text { productivity } \\
\text { agriculture and } \\
\text { abandonment } \\
\text { of previously } \\
\text { large pastures } \\
\text { and meadows } \\
\text { leading to } \\
\text { succession; } \\
\text { intensive fish } \\
\text { farming }\end{array}$ \\
\hline Other & $\begin{array}{l}\text { Climate change, } \\
\text { especially } \\
\text { affecting } \\
\text { coastal areas; } \\
\text { deforestation; } \\
\text { soil erosion }\end{array}$ & $\begin{array}{l}\text { Climate } \\
\text { change; } \\
\text { acidification of } \\
\text { habitats; forest } \\
\text { fires; invasive } \\
\text { species }\end{array}$ & Climate change & $\begin{array}{l}\text { Climate change; } \\
\text { forest fires }\end{array}$ & $\begin{array}{l}\text { Climate change; } \\
\text { invasive species }\end{array}$ & Forest fires & $\begin{array}{l}\text { Climate } \\
\text { change; } \\
\text { invasive } \\
\text { species; forest } \\
\text { fires }\end{array}$ \\
\hline
\end{tabular}

\subsection{Valuation of ecosystem services}

It is widely recognized nowadays that ecosystems provide a range of valuable services for people, many of which are of essential importance for human health, livelihood and survival. The importance of ecosystem services, i.e. the benefits derived from ecosystems, started to gain attention through the Millennium Ecosystem Assessment (2005). Ecosystem services 'can include provisioning services such as food and water; regulating services such as regulation of floods, drought, land degradation, and diseases; supporting services such as soil formation and nutrient cycling; and cultural services such as recreational, spiritual, religious and other non-material benefits' (Millennium Ecosystem Assessment, 2005). Continuing degradation of nature, depletion of natural resources and concern for future generations brought a new dimension to the valuation of ecosystem services: the economic one. The value of ecosystems to society, including the cost of their degradation and ultimately their loss, need to be adequately accounted for.

Nature conservation policies have started to acknowledge the importance of valuation of ecosystem services. One of the most important global strategic policy documents, the CBD Strategic Plan for Biodiversity 2011-2020 with its Aichi Biodiversity Targets, calls for enhancement of benefits to all from biodiversity and ecosystem services (Target 2) (UNEP/ CBD COP 10, 2010). The EU Biodiversity Strategy to 2020, through its Target 2, also calls for maintenance and restoration of ecosystems and their services. In particular, under Action 5, the members of the EU are obliged to map and assess the ecosystems and their services on their national territory (European Commission, 2011). 
The EU Members States in SEE, Croatia and Slovenia, have not yet completed national level mapping and assessment of their ecosystems and services, as a fulfilment of commitments to the EU Biodiversity Strategy to 2020. In fact, such an assessment has not been performed in any of the SEE countries, except in Montenegro, where two assessments estimated the value of protected areas and the value of biodiversity and ecosystem services (published in 2011 and 2013, respectively).

The majority of the national reports noted that valuation of ecosystem services is a relatively novel concept for them, so there were no attempts to perform an assessment at the national scale. Studies developed in the SEE countries focus largely on specific sites rather than covering the whole national territory or regions within the country. These studies were performed by various institutions, including government institutions, but mainly by local and international NGOs, scientists and students, within the scope of certain projects or as part of academic research. The assessments in the SEE focused on services provided by freshwaters (in BiH, Croatia, Macedonia, Montenegro, Serbia, and Slovenia), mountains (in Albania, Croatia, Macedonia, Serbia, and Slovenia), forests (in Albania, BiH, and Serbia), and caves (in Slovenia).

Generally, most countries of the SEE region lack a strategic approach and understanding of the concept of valuation of ecosystem services, thus studies are done sporadically. Although small-scale and specific site-based projects have been important in raising awareness of local communities about the value of nature for human well-being, there is still much room for improving the understanding and implementation of methodologies for valuation of ecosystem services is needed in SEE region to justify public expenditure in the field of conservation and continuous provision of these services; for priority setting for conservation and use of natural resources; and to raise public awareness about the value of nature in SEE. IUCN ECARO, in cooperation with GIZ Open Regional Fund for South-East Europe - Biodiversity (ORF BD), conducted training on ecosystem services valuation and assessment in Razma, Albania in 2016, based on the Capacity Building Programme developed through the project 'Towards strengthened conservation planning in South-Eastern Europe'. This was the first in a series of training sessions aimed at building capacity and understanding of the purpose of valuation of ecosystem services. Two additional training sessions were planned for 2017.

IUCN ECARO, responding to the needs of partner institutions, initiated two scoping studies to look at Nature-based Solutions (NbS) and their role in disaster risk reduction and climate change adaptation. One study focuses on the situation in Albania, and another in Serbia, under the 'Towards Strengthened Conservation Planning in South-Eastern Europe' project. ORF BD also initiated pilot case studies under the Ecosystem Services Assessment and Valuation (ESAV) sub-project. At the regional level, IUCN ECARO has partnered with the German Federal Agency for Nature Conservation (BfN) to look at natural solutions for disaster risk reduction and climate change adaptation with a focus on flood prevention in SEE. Studies will inform a full-scale regional project on Nature-based Solutions and ecosystem-based disaster risk reduction (Eco-DRR).

\subsection{Nature information systems}

Biodiversity monitoring is generally weak in the SEE region, resulting in insufficient and scarce availability of relevant data, often based on old literature and sporadic research. The situation with the establishment of nature information systems at the national level varies from country to country (Table 20). Croatia and Slovenia have progressed the most in this aspect. In Croatia, five nature-relevant databases are currently operational, including those containing information on flora, fauna, habitats, Natura 2000 and protected areas, but not all are available publicly. The sixth database, containing speleological information, is under development. All of them form part of the national Nature Protection Information System managed by the State Institute for Nature Protection (now part of the Croatian Agency for Environment and Nature). As noted in Table 20 , the databases are either fully or partially publicly available.

In Slovenia, the Nature Conservation Atlas has been developed, containing comprehensive information on Natura 2000, protected areas, habitats, ecologically important areas, valuable natural features, nature conservation guidelines, conservation measures and management. The database is partially publicly available.

In Serbia, the Institute for Nature Conservation of Serbia manages the Central Register of Protected Natural Areas of Serbia that is not available to the public. Databases on species and habitats have not yet been completed or fully digitised. In Serbia, unlike in other countries, there are a number of nature databases developed by NGOs and universities, e.g. BioRaS contains open access to collated data on species and habitats and is kept by several NGOs, Biodiversity of Aquatic Ecosystems in Serbia has been developed by the Faculty of Mathematics and Natural Sciences in Kragujevac, while the List of Invasive Species has been prepared by the Faculty of Mathematics and Natural Sciences in Novi Sad. 
In two countries, Albania and Macedonia, nature-related information databases have been established but are not operational. Nature information in Albania is contained within a broader database, the Environmental Information Monitoring System, while in Macedonia, there is the non-functional National Information System for Biodiversity.

In $\mathrm{BiH}$ and Montenegro, nature information databases have not yet been established due to serious challenges with research and inventorying of biodiversity, lack of adequate data, and lack of resources. Nevertheless, in Montenegro, progress has been made with the development of the National Information System on Environment, which includes information on biodiversity, and the Database on Protected Areas. Both databases are still under development. A workshop on Streamlining Biodiversity Data was organised by IUCN in Sarajevo, BiH in 2016, resulting in a set of recommendations for those two countries on how to start building systems for data collection, recording and maintenance.

Table 20 Environmental information systems managed by government institutions in the SEE countries

\begin{tabular}{|c|l|l|}
\hline Country & \multicolumn{1}{|c|}{ Database } & \multicolumn{1}{|c|}{ Status } \\
\hline \multirow{2}{*}{ Albania } & Environmental Information Monitoring System & Non-functional \\
\hline \multirow{5}{*}{ Croatia } & None & \\
\cline { 2 - 3 } & Nature Protection Information System: & \\
\cline { 2 - 3 } & CRO Fauna & Operational, partially publicly available \\
\cline { 2 - 3 } & CRO Flora & Operational, partially publicly available \\
\cline { 2 - 3 } & CRO Speleo & In development \\
\cline { 2 - 3 } & Natura 2000 & Operational, publicly available \\
\cline { 2 - 3 } & Protected areas & Operational, publicly available \\
\hline \multirow{2}{*}{ Macedonia } & National Information System for Biodiversity & Operational, publicly available \\
\hline \multirow{2}{*}{ Montenegro } & National Information System on Environment & Under development \\
\cline { 2 - 3 } & Database on Protected Areas & Under development \\
\hline \multirow{2}{*}{ Serbia } & Central Register of Protected Natural Areas of Serbia & Operational, not publicly available \\
\cline { 2 - 3 } & National Information System on Environment & Operational, partially publicly available \\
\hline \multirow{2}{*}{ Slovenia } & Nature Conservation Atlas & Operational, partially publicly available \\
\hline
\end{tabular}

\subsection{Financing nature conservation}

The national reports primarily focused on financing protected areas, and thus this Chapter also reviews this topic. Nevertheless, it should be noted that financing nature conservation also includes elements other than protected areas, such as protection of species, research related to biodiversity, monitoring, assessments, evaluation of state of biodiversity, preparation of strategies and reports, etc.

Financing protected areas is important not only to cover the direct and indirect costs related to protected area administration, but to contribute towards effective and long-term conservation of nature (Emerton et al., 2006). Financial resources for protected areas may be generated by different sources; most commonly these are the national level sources, international sources, and site level sources (Financing Protected Areas Task Force of the World Commission on Protected Areas (WCPA) of IUCN, in collaboration with the Economics Unit of IUCN, 2000). All of these sources are evident in the SEE region (Table 21).

At the national level, financing of protected areas in SEE is largely based on state budget funding. To a much lesser extent, financing comes from municipal budgets.

International funding includes five main sources (Table 21). Multilateral agencies finance various nature conservation projects, and the main donors include the World Bank (WB), the EU, the Global Environment Facility (GEF), the Green Climate Fund (GCF) and the Critical Ecosystem Partnership Fund (CEPF). Bilateral aid agencies, including ADA, AISC, BMUB, BMZ, JICA, Norad, SDC, SIDA, USAID, are another source of financing. The third source is funding received by foreign national governments, such as the embassies or relevant ministries of Germany, Finland, Norway, The Netherlands, Switzerland, and 
the United States of America. The fourth source of funding comes from private foundations, largely the Swiss-based MAVA Foundation. The fifth source includes development banks, such as KfW.

A general characteristic of financing nature conservation in the SEE countries in the past two decades is their dependency on external funding sources, as illustrated in Annex I. The international donor funding of nature conservation in SEE is well justified by the abundant biodiversity in the region and cost-efficiency of investment in its conservation. This is an important funding scheme for the region; however, external support has two unintended negative consequences. The first is that the decision-makers seem to believe that it is not necessary to provide sufficient domestic funding for nature conservation as funds are available from abroad. This leads to the weakening of core conservation institutions as they cannot employ sufficient number and quality of staff, and rely on project funding and project based ad-hoc external expertise. The second is the potential idea that nature conservation is mainly in the interest of international organisations and foreign countries and not in the primary public interest of the countries themselves. This leads to political de-legitimisation of conservation institutions and NGOs in the decision-making processes at various levels, in particular in procedures of issuing concessions, impact assessments and permitting.

At the site level, some protected areas generate income and reinvest it in conservation by collecting different user fees. Most countries charge entrance fees to some of their protected areas, usually national parks. User fees also include charging of parking and concessionaires profiting from providing lodging, food and beverage, and guiding tours. Concessions were reported only by the authorities in Croatia and Montenegro, while the collection of fees for sustainable use of natural resources was reported by the authorities in Montenegro and Serbia. In terms of tourism, the national reports of Montenegro, Serbia and Slovenia all reported this type of income for nature conservation. In Croatia, most of the revenue gained by tourism in protected areas is not reinvested in nature conservation but to further tourism.

Table 21 Funding sources for nature conservation sector in the SEE region

\begin{tabular}{|c|c|c|}
\hline \multicolumn{2}{|c|}{ Funding sources in the SEE region } & Site level \\
\hline National level & International level & User fees \\
\hline State budget & Multilateral agencies & Tourism \\
\hline Municipal budget & Bilateral agencies & \\
\hline & Foreign governments & \\
\hline & Private foundations & \\
\hline
\end{tabular}

Source: National reports

By looking at public institutions for national parks in the SEE region, their financing is a combination of sources (Table 21), although the relations between these types of financing differs among the countries. While national park administration in Albania and $\mathrm{BiH}$ is mainly state funded, in Macedonia it is self-financed. This ratio also depends on the following elements:

- Category of protection - protected areas with strict protection regime rely more or entirely on the state budget, while other protected areas depend also on funding generated by tourism, various fees, concessions and timber production

- Authority responsible for distribution of funds generated by national parks - in Albania the funds are allocated directly to the state budget, leaving the national parks without their own income and making them dependent on state financing, while in Macedonia and Croatia, protected areas are authorized for managing these funds, increasing the level of financial sustainability of the national parks

- Ability of protected area managers to secure sustainable financing.

The information about financing provided in the national reports is not unified throughout the reports, making a sound analysis difficult. For example, the authorities from Albania and Croatia provided information of their state budgets spanning several years in relative terms (percentage of the overall budget) and without including absolute amounts (EUR streamlined to protected areas), while the authorities from Macedonia and Serbia provided absolute figures in EUR. Other countries did not provide any similar information. Some reports included the information on the sources of income for national parks in absolute amounts or percentages, while others noted the budget of their national parks, or did not provide any statistical information. Therefore, a detailed comparison between countries is not possible. However, all the reports, except for BiH and Montenegro which did not communicate this information, noted that state financing of protected areas varies from year to year and the general trend seems to be more or less declining. This trend is worrying as protected areas designated by governments to protect the most valuable natural assets of the countries should primarily be under the responsibility of these governments. 
All national reports noted that there is a prominent need for improvement of their existing funding schemes in order to ensure sustainable financing for protected areas. Also, the unfavourable structure of expenditures in protected areas does not help to improve the situation. There is an obvious need to enlarge state budget allocations for nature conservation activities and programmes. Most of the revenue is allocated for salaries, overhead and tourism development, and only small amounts for actual nature conservation (i.e. site management), thus the central state budgets are generally insufficient to secure the long-term conservation of nature. Such a situation leads to the conclusion that in most SEE countries, protected areas do not seem to be effectively managed.

To ensure operational sustainability of protected areas in the long-term, there is a need for stable and versatile sources of funds. Some funding opportunities ${ }^{25}$ lay in:

- Enlargement of state budget allocations for nature conservation to ensure effective conservation.

- Enhancement of funding schemes that are ongoing in most countries, with the view to ensuring the state of conservation of protected areas is not jeopardized:

- collecting entrance fees where applicable and including price differentiation,

diversified offer in souvenir shops,

developing tourism-related and other concessions effectively,

enabling stronger links between local agriculture and tourism in protected areas (e.g. promoting organic brands), charging for the utilization of natural resources,

'special' offerings to extend the season to attract more visitors and for a greater spread of visitors, etc.

- Donor funding - all of the countries benefit from donations to a certain extent. There is room for improvement in both the quantity (amount of funds attracted) and quality (donations could target protected areas directly, and especially their conservation activities and programmes).

- Alternative financing opportunities whose potential is not presently exercised or exists in isolated cases. Some of the potential instruments to explore are:

- $\quad$ engaging in public-private partnerships or considering privatisation (e.g. in management of restaurants and hotels located in protected areas where applicable),

- $\quad$ establishing partnerships with NGOs and volunteers to reduce some protected area costs (e.g. in conservation activities and research),

establishing funds dedicated to protected areas,

corporate donations,

charging visitors for some of the additional activities offered by a protected area,

alternative ways of charging an entrance fee in multiple-entrance sites that are not easy to control,

- biodiversity offset mechanisms, meaning measurable conservation outcomes resulting from actions designed to compensate for significant residual adverse biodiversity impacts arising from development plans or projects after appropriate prevention and mitigation measures have been taken (Business and Biodiversity Offsets Programme, 2012); the so called No Net Loss for biodiversity,

- revenues from payments for ecosystem services (e.g. water supply, flood control),

- carbon offsets emerging from obligations under the Kyoto Protocol (e.g. projects reducing the emission of greenhouse gasses, e.g. in forests, Posidonia oceanica),

- redistribution of the existing revenues from taxes, duties and charges levied on fossil fuel production, forestry concessions, licenses for fishing, hunting, filming or other activities,

- streamlining part of the tourist tax to nature conservation (e.g. accommodation tax),

- potential commercial use of some invasive species that endanger native species,

- species 'adoption' programmes.

Implementation of a tool to track the progress of financial sustainability of protected areas would be highly recommended for the region. An example of the implementation of such tool is found in Serbia, where the Financial Scorecard of UNDPdeveloped protected areas showed that the 'financial health' of the protected area system in Serbia increased from $27.6 \%$ in 2009 to $38.7 \%$ in 2013.

25 Useful sources of guidance for financing protected areas apart from the references already noted in this Chapter are: Conservation Finance Network (http://www.conservationfinancenetwork.org), Conservation Finance Alliance (http://www.conservationfinance.org), The World Bank (2010), and specifically for transboundary conservation initiatives, Vasilijević et al. (2015). 


\subsection{Capacity needs in the nature conservation sector}

Capacity development is often understood as attending training courses to build individual capacities. In line with that, most of the national reports noted or discussed the training workshops held in their countries and attended by staff of the relevant government institutions involved in nature conservation. However, capacity development is more than undertaking training to develop skills in a certain field of work. UNDP (1997) defines capacity development as 'the process by which individuals, organizations, institutions and societies develop abilities (individually and collectively) to perform functions, solve problems and set and achieve objectives.' This definition recognizes that capacity can be developed at three distinct but related levels:

- Enabling people to develop and use the competences (skills, knowledge and behaviour) required to do their jobs well builds individual capacity

- Establishing and sustaining entities of all types that take responsibility for protected areas and the people who work for their future builds organisational capacity

- Creating an 'enabling environment' that politically, economically, and culturally recognizes the values of protected areas and enables them to thrive builds societal capacity (Appleton, 2016).

Having in mind the content of the national reports, this Chapter focuses on the synthesis of capacity needs in nature conservation, mainly at the individual level and corresponding organisational level. Table 22 provides the information on the most relevant capacity needs in the SEE countries, as reported by the national authorities, and also supplemented by the relevant information provided in the countries' NBSAPs. In all countries except Slovenia, there seems to be a need for strengthened capacities in biodiversity data management, including technical skills such as operative knowledge of the Geographic Information System. Also, all the national reports except Macedonia's detected the need to improve the nature conservation staff's communication skills and visitor management, as a way to better promote nature conservation, the role and value of protected areas, establish efficient relations with the media, and balance the visitors' impact on protected areas through careful planning of tourism and calculation of the carrying capacity for a certain area. Tourism is generally a growing industry in the region and thus cautious planning and management of visitors and tourism is highly necessary.

The need to build capacity in the economic valuation of ecosystem services was detected in all national reports except Albania's, while all reports but Macedonia's highlighted the necessity to gain skills in the ways of establishing partnerships and enabling a participatory approach in protected area management, including conflict resolution. The Montenegrin and Slovenian reports particularly noted the need to strengthen knowledge on the modalities of pursuing relevant compensation measures in protected areas.

Strengthening capacities in protected area management and management planning was detected as important in all countries except Croatia and Slovenia. Related to this, Albania's national report particularly addressed the importance of focusing on marine protected areas, and on zoning. This country faces challenges with appropriate staffing of protected area administration, thus establishing an effective administration with qualified staff is another priority. In Montenegro, evaluating management effectiveness was highlighted as a priority for capacity development.

Monitoring of biodiversity, conservation planning (including for Natura 2000 sites in Macedonia and beyond protected areas in Albania), financing of protected areas and field ranger skills were identified in several countries as areas in which skills and knowledge are needed.

Most countries detected some specific needs that cannot be categorized in any of the categories shown in Table 22 . In Croatia capacity development needs include the areas of law enforcement and business organisation, in Macedonia the implementation of relevant EU policy, and in Montenegro the methodology for Red List development and project management. Insufficient knowledge of conservation biology and nature conservation was highlighted in the reports of Croatia, Montenegro and Serbia. It is, however, probable that other SEE countries (perhaps with the exception of Slovenia) face a similar challenge.

Generally, as visible in Table 22, most countries in SEE lack adequate capacities for effective nature conservation. In order to support national conservation planning systems in SEE, IUCN ECARO published a report on capacity development needs and priorities for nature conservation in 2016. The report is based on a capacity analysis performed by adjusting the UNDP Protected Area Capacity Scorecard. The results showed that the overall capacity scores were weak, with none greater than $60 \%$. Slovenia and Macedonia did not participate in this study, while other countries showed a moderate capacity level (Albania, Croatia and Serbia), or significantly weak level (BiH and Montenegro). 
In several countries (e.g. Albania, BiH) institutional problems hinder effective nature conservation. The challenges include regular reorganisation of institutions, personnel changes following political changes, weak institutional cultures, in addition to a lack of technical capacities among staff. $\mathrm{BiH}$ noted that one of its priorities is the establishment of an effective nature conservation system.

Table 22 Main capacity needs for strengthening nature conservation in the SEE countries

\begin{tabular}{|c|c|c|c|c|c|c|c|}
\hline Main capacity needs & 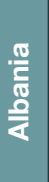 & $\frac{T}{m}$ & $\frac{\sqrt{0}}{\frac{10}{70}}$ & 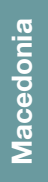 & 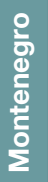 & $\begin{array}{l}\frac{\Phi}{\circ} \\
\frac{2}{5} \\
\text { ळ }\end{array}$ & 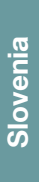 \\
\hline Data management (database development and maintenance, Geographic Information System (GIS)) & $\bullet$ & $\bullet$ & $\bullet$ & $\bullet$ & $\bullet$ & $\bullet$ & \\
\hline $\begin{array}{l}\text { Communication skills and visitor management (raising public awareness, media relations, interpretation and } \\
\text { marketing, determining carrying capacity) }\end{array}$ & $\bullet$ & $\bullet$ & $\bullet$ & & $\bullet$ & • & - \\
\hline Valuation of ecosystem services (and sustainable community development) & & $\bullet$ & $\bullet$ & - & $\bullet$ & $\bullet$ & $\bullet$ \\
\hline $\begin{array}{l}\text { Establishing partnerships (in protected area management, stakeholder participation, cross-sectoral } \\
\text { cooperation, conflict resolution, compensatory measures) }\end{array}$ & & $\bullet$ & $\bullet$ & & $\bullet$ & & $\bullet$ \\
\hline Protected area management (including Natura 2000) & $\bullet$ & $\bullet$ & & $\bullet$ & $\bullet$ & $\bullet$ & \\
\hline Monitoring of biodiversity & $\bullet$ & $\bullet$ & & $\bullet$ & $\bullet$ & & \\
\hline Conservation planning & $\bullet$ & $\bullet$ & $\bullet$ & $\bullet$ & & & \\
\hline Financing nature conservation (detecting funding sources, project management cycle and financial reporting) & $\bullet$ & $\bullet$ & • & & • & $\bullet$ & \\
\hline Field ranger skills (first aid, navigation, search and rescue) & & - & $\bullet$ & • & $\bullet$ & & \\
\hline
\end{tabular}

Source: National reports; NBSAPs 


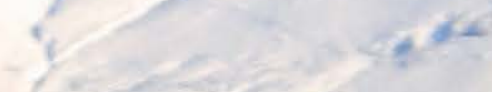

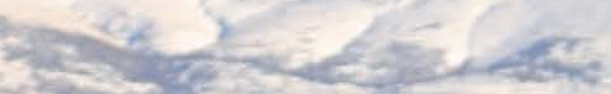

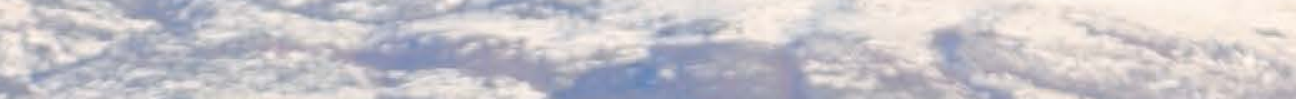

\section{Recommendations}

\section{Maja Vasilijević}

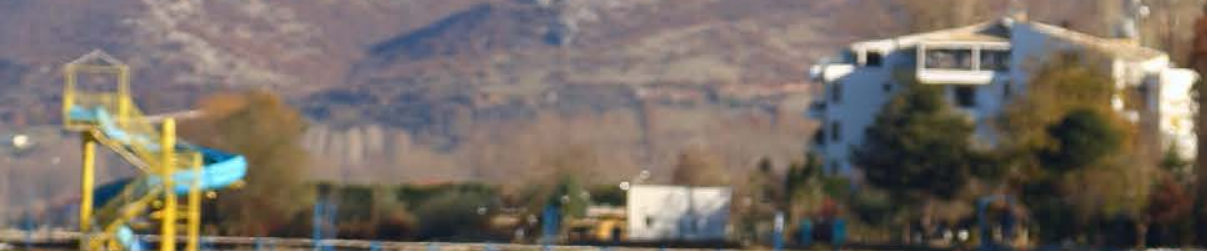

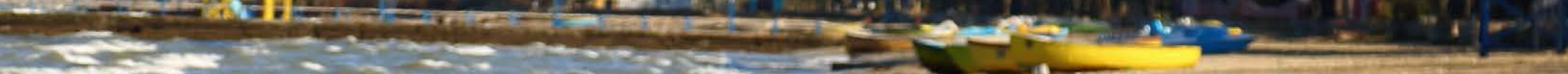

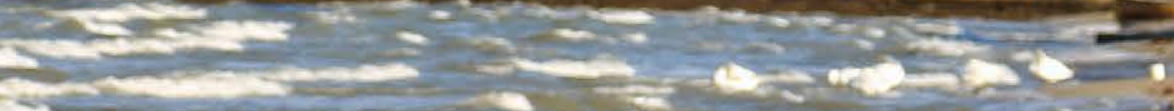
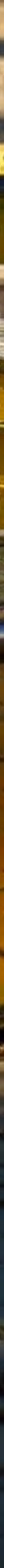
National nature conservation systems in the SEE region differ to a greater or lesser extent, some being more successful and efficient than others. What makes these systems similar is that they do not take into account that they are part of a wider region, and that there is lack of regional perspective in dealing with conservation issues. Recognising the importance of transboundary coherence and viewing conservation issues and challenges from the regional perspective is largely missing and does not seem to be a priority of individual countries. This is especially amplified by the fact that the region largely shares a common history, cultural similarities and language, including relatively unspoiled nature. Although a number of initiatives and projects (see Annex I for the list of the most important projects in all countries) have helped to improve regional and/or bilateral cooperation in nature conservation over the past decade, coherent and integrative regional strategies are still lacking.

This Chapter proposes a set of recommendations with a view to strengthen nature conservation systems in the SEE region. The proposed recommendations are, in most cases, relevant to all countries.

\section{Proposed recommendations for strengthening nature conservation systems in the SEE region}

\section{Institutional and legal systems and biodiversity strategies}

1.1. Work towards establishing relevant institutions where they are missing (e.g. expert technical institutions for nature conservation) to support strengthening the institutional structures and sustainable financing at the national level.

1.2. Strengthen the administrative capacity of state institutions to ensure continued and long-term efficiency.

1.3. Raise the capacity of the civil society to strengthen the activities of nature conservation NGOs, especially those related to nature conservation-related research work, influence on policy and environmental education.

1.4. Complete, as much as possible, functional transposition of the EU Habitats and Birds Directives into the national legislation systems.

1.5. Enforce the implementation of the existing legislation as to enhance management effectiveness of protected areas and minimise illegal activities in protected areas.

1.6. Where relevant, revise NBSAPs by ensuring alignment of national objectives and targets with the global CBD Strategic Plan for Biodiversity 2011-2020 and Aichi Targets and the EU Biodiversity Strategy to 2020.

\section{Conservation planning and management effectiveness}

2.1. Strengthen the strategic conservation planning process at the national level, while also developing a mechanism to achieve strategic conservation planning at the SEE regional level.

2.2. Set conservation management as a priority for protected areas and increased management effectiveness of protected areas through sound planning, conservation management and monitoring used as a feedback for further planning.

2.3. Ensure full stakeholder participation in conservation planning and management to provide for transparency, consultation and involvement.

2.4. Develop management plans for relevant protected areas and secure their permanent implementation, including funding.

2.5. Develop management plans for key species and secure their permanent implementation, including funding.

2.6. Develop and/or enhance biodiversity monitoring systems and support regular data collection. In doing so, relevant internationally recognized methodologies (e.g. IUCN WCPA Management Effectiveness Framework) and EU requirements should be consulted and taken into account.

2.7. Enhance knowledge about the establishment, management and protection of Natura 2000 sites in non-EU Member States.

\section{Transboundary conservation and regional cooperation}

3.1. Encourage the establishment of Transboundary Conservation Areas for better coordination of conservation measures, strengthening of cooperation between protected areas, local communities, NGOs and governments, and generation of new economic opportunities.

3.2. Support implementation of transboundary conservation governance models, including formal and informal arrangements, for the conservation of transboundary ecosystems and migratory species.

3.3. Consult European and global best practices in transboundary conservation processes in achieving the full potential of transboundary conservation initiatives. 
3.4. Facilitate social events to promote the building of trust and friendship among local stakeholders from different countries in both active and potential Transboundary Conservation Areas.

3.5. Support transboundary conservation projects for species management and conservation.

3.6. Enhance networking between conservationists from the region including specific site visits in order to share experience and contribute to the improvement of knowledge and skills.

3.7. Use Biodiversity Task Force as a regional cooperation platform and build on the Big Win for Dinaric Arc regional agreements from 2008 and 2013 to strengthen nature conservation systems.

3.8. Improve the national legislation to consider transboundary conservation needs, including the bodies in charge of the transboundary conservation process.

\section{Protected area coverage}

4.1. Expand the network of terrestrial protected areas where applicable and secure their good governance and effective management, as to contribute to Aichi Target 11.

4.2. Prioritize the establishment of marine protected areas where applicable and secure their good governance and effective management, and thus contribute to Aichi Target 11.

\section{Governance of protected areas}

5.1. Ensure better understanding of the concept of governance of protected areas, emphasizing its importance for stronger and sustainable nature conservation systems.

5.2. Raise awareness about various protected area governance types to ensure their diversification and implementation of those most relevant to the SEE region in terms of political and cultural context.

5.3. Build capacity of national decision-makers on understanding different types of protected area governance and their practical implementation.

5.4. Provide enabling conditions for implementing diverse governance types in protected areas, as to achieve the full potential of good governance and enable strong participatory processes. This can be achieved through legislative provisions ensuring flexibility in protected area governance.

\section{Valuation of ecosystem services}

6.1. Raise awareness about the value of natural capital for the national economy and human well-being.

6.2. Ensure better understanding of the concept of ecosystem services in order to avoid its misuse and commodification of nature.

6.3. Raise the capacity on available methods of valuation of ecosystem services and improve assessments of the value of ecosystems at the national level.

6.4. Identify direct and indirect benefits of protected areas for local stakeholders and the society, and communicate them effectively to raise support for protected areas and nature conservation.

\section{Cross-sectoral cooperation}

7.1. Work towards integration of nature conservation objectives into the objectives of other sectors (e.g. spatial planning, agriculture, forestry, etc.).

7.2. Reduce the negative impact on protected areas caused by unsustainable tourism in areas with high tourism pressures. This could be achieved by calculation of the carrying capacity and development and implementation of sustainable tourism planning strategies.

7.3. Set clear limits to patterns of unsustainable use of natural resources.

\section{Financing nature conservation}

8.1. Strengthen the implementation of protected area funding schemes most commonly used in the SEE countries, i.e. financing from the state budget, always ensuring the state of conservation is not negatively impacted. 
8.2. Explore and implement alternative protected area funding schemes to strengthen support for nature conservation.

8.3. Enrich the structure of expenditures in protected areas, i.e. streamline finances to concrete nature conservation activities and programmes.

\section{Knowledge management}

9.1. Develop knowledge information systems on nature and ensure their public availability.

9.2. Ensure cooperation between relevant institutions in the region to align biodiversity data collection and storing systems.

9.3. Ensure necessary support for the assessment of conservation status and distribution of species as to undertake effective measures to protect and conserve relevant species. 


\section{References}

Anastasovski, V. (2014). Assessment of the State of Nature Conservation Systems in South-Eastern Europe: Macedonia. Unpublished report.

Appleton, M. R. (2016). Towards strengthened conservation planning in South-Eastern Europe: Capacity Development Needs and Priorities for Nature Conservation in South-Eastern Europe. Gland, Switzerland and Belgrade, Serbia: IUCN Regional Office for Eastern Europe and Central Asia (ECARO). vi + 46pp. https://portals.iucn.org/library/node/45924

Avramoski, O., Erg, B., Pezold, T. (2016). Initial Assessment of Protected Areas in Albania Using the Management Effectiveness Tracking Tool. Tirana: NaturAL. <https://www.iucn.org/sites/dev/files/content/documents/2016/analysis_of_mett_results_final.pdf>. Accessed on 1 March 2017.

Bataković, M. and Staničić, N. (2014). Assessment of the State of Nature Conservation Systems in South-Eastern Europe: Republic of Montenegro. Unpublished report.

Bennett, G. (2004). Integrating Biodiversity Conservation and Sustainable Use: Lessons Learned from Ecological Networks. IUCN, Gland, Switzerland and Cambridge, UK. vi +55 pp. https://portals.iucn.org/library/node/8355

Bennett, G. and Wit, P. (2001). The Development and Application of Ecological Networks: a Review of Proposals, Plans and Programmes. Amsterdam: AIDEnvironment. https://portals.iucn.org/library/node/7960. Accessed on 1 April 2015.

Bino, T. and Bego, F. (2014). Assessment of the State of Nature Conservation Systems in South-Eastern Europe: Albania. Unpublished report.

Bolješić, R. and Groznik Zeiler, K. (eds.). (2015). The Fifth National Report on the Implementation of Convention on Biological Diversity. Ljubljana: Ministry of the Environment and Spatial Planning of the Republic of Slovenia. <https://www.cbd.int/doc/world/si/si-nr-05-en.pdf>. Accessed on 22 December 2016.

Borrini-Feyerabend, G., Dudley, N., Jaeger, T, Lassen, B., Pathak Broome, N., Phillips, A. and Sandwith, T. (2013). Governance of Protected Areas: From Understanding to Action. Best Practice Protected Area Guidelines Series No. 20. Gland, Switzerland: IUCN. xvi + 124 pp.https://portals.iucn.org/library/node/29138. Accessed on 11 February 2015.

Brajanoska, R., Cil, A., Civic, K., Jones-Walters, L., Heinrichs, A.K., Hristovski, S., Melovski, Lj. and Schwaderer, G. (2013). Synthesis report of the project "Realisation of the Balkan Regional Ecological Network". Skopje: ECNC-European Centre for Nature Conservation, EuroNatur Foundation, Macedonian Ecological Society.

Burbidge, T., Civic, K., Delbaere B. and Schrauwen, A. (2015). Initiatives related to mapping and assessment of ecosystems and their services in EECCA and SEE countries - Scoping Document. Tilburg, the Netherlands: ECNC. <https://www.ecnc.org/uploads/2015/02/Initiativesrelated-to-mapping-and-assessment-of-ecosystems-and-their-services-in-EECCA-and-SEE-countries-scoping-document.pdf>. Accesses on 23 February 2017.

Business and Biodiversity Offsets Programme (BBOP) (2012). Biodiversity Offset Design Handbook-Updated. Washington, D.C.: BBOP. <http:// bbop.forest-trends.org/guidelines/Updated_ODH.pdf>. Accessed on 21 December 2016.

Chapron, G., Kaczensky, P., Linnell, J.D.C., von Arx, M., Huber, Dj., Andrén, H., López-Bao, J.V., Adamec, M., Álvares, F., Anders, O., Balčiauskas, L., Balys, V., Bedő, P., Bego, F., Blanco, J.C., Breitenmoser, U., Brøseth, H., Bufka, L., Bunikyte, R., Ciucci, P., Dutsov, A., Engleder, T., Fuxjäger, C., Groff, C., Holmala, K., Hoxha, B., lliopoulos, Y., lonescu, O., Jeremić, J., Jerina, K., Kluth, G., Knauer, F., Kojola, I., Kos, I., Krofel, M., Kubala, J., Kunovac, S., Kusak, J., Kutal, M., Liberg, O., Majić, A., Männil, P., Manz, R., Marboutin, R., Marucco, F., Melovski, D., Mersini, K., Mertzanis, Y., Mysłajek, R.W., Nowak, S., Odden, J., Ozolins, J., Palomero, G., Paunović, M., Persson, J., Potočnik, H., Quenette, P-Y., Rauer, G., Reinhardt, I., Rigg, R., Ryser, A., Salvatori, V., Skrbinšek, T., Stojanov, A., Swenson, J.E., Szemethy, L., Trajçe, A., Tsingarska-Sedefcheva, E., Váňa, M., Veeroja, R., Wabakken, P., Wölfl, M., Wölfl, S., Zimmermann, F., Zlatanova, D., Boitani, L. (2014). Recovery of large carnivores in Europe's modern human-dominated landscapes. Science Direct 346: 1517. https:// doi.org/10.1126/science. 1257553

Council of Europe (2014). List of Candidate Emerald Sites (December 2014). 34 ${ }^{\text {th }}$ Meeting of the Standing Committee of the Convention on the conservation of European wildlife and natural habitats. <http://www.coe.int/t/dg4/cultureheritage/nature/econetworks/portal_en.asp>. Accessed on 23 March 2015.

Council of Europe (2016). The Emerald Network: A Network of Areas of Special Conservation Interest for Europe. Explanatory document and compilation of relevant texts. <https://wcd.coe.int/com.instranet.InstraServlet?command=com.instranet. CmdBlobGet\&InstranetImage=2923168\&SecMode=1\&Docld=2377796\&Usage=2>. Accessed on 10 April 2017.

Croatia Ministry of Environmental and Nature Protection (2014). Fifth National Report of the Republic of Croatia to the Convention on Biological Diversity. <https://www.cbd.int/doc/world/hr/hr-nr-05-en.pdf>. Accessed on 20 March 2016. 
Croatian Agency for Environment and Nature (2015). Protected Areas of Croatia. <http://www.bioportal.hr>. Accessed on 23 March 2017.

Deltshev, C. (2004). 'A Zoogeographical Review of the Spiders (Araneae) of the Balkan Peninsula'. In: Griffiths, H. I., Kryštufek, B. and Reed, J.M. (eds.). Balkan Biodiversity Pattern and Process in the European Hotspot, pp. 193-200. Dordrecht, Boston, London: Kluwer Academic Publishers. https://doi.org/10.1007/978-1-4020-2854-0_11

Dudley, N. (ed.) (2008). Guidelines for Applying Protected Area Management Categories. Gland, Switzerland: IUCN. https://doi.org/10.2305/ IUCN.CH.2008.PAPS.2.en Dudley, N., Shadie, P. and Stolton, S. (2013). Guidelines for Applying Proteced Area Management Categories including IUCN WCPA Best Practice Guidance on Recognising Protected Areas and Assigning Management Categories and Governance Types. Best Practice Protected Area Guidelines Series No. 21. Gland, Switzerland: IUCN. https://portals.iucn.org/library/node/30018. Accessed on 11 February 2015.

Đokić, T. (2014). Assessment of the State of Nature Conservation Systems in South-Eastern Europe: Republic of Slovenia. Unpublished report.

European Commission (2011). Our Life Insurance, Our Natural Capital: An EU Biodiversity Strategy to 2020. <http://eur-lex.europa.eu/legalcontent/EN/TXT/?uri=CELEX:52011DC0244>. Accessed on 22 March 2015.

European Environment Agency (EEA) (2012). Protected Areas in Europe-An Overview. EEA Report No 5/2012. Copenhagen: EEA.

Environmental Protection Agency (EEA) (2015). Project: Revalidation of Ecological Values and Management Arrangements of Existing Protected Areas. Podgorica, Montenegro.

Ervin, J. (2003). WWF: Rapid Assessment and Prioritization of Protected Area Management (RAPPAM) Methodology. Gland, Switzerland: WWF. $<$ http://www.panda.org/downloads/forests/rappam.pdf>. Accessed on 1 March 2017.

Federal Ministry of Environment and Tourism (2014). Fifth National Report to the United Nations Convention on Biological Diversity of Bosnia and Herzegovina. <https://www.cbd.int/doc/world/ba/ba-nr-05-en.pdf>. Accessed on 20 March 2016.

Financing Protected Areas Task Force of the World Commission on Protected Areas (WCPA) of IUCN, in collaboration with the Economics Unit of IUCN. Phillips, A. (ed.) (2000). Financing Protected Areas: Guidelines for Protected Area Managers. IUCN, Gland, Switzerland and Cambridge, UK. viii + 58pp.https://doi.org/10.2305/IUCN.CH.2000.PAG.5.en . Accessed on 21 December 2016.

Freyhof, J. (2012). Threatened Freshwater Fish and Molluscs of the Balkan: Potential Impact of Hydropower Projects. Unpublished report. ECA Watch \& Euronatur.

Graham, J., Amos, B. and Plumptre, T. (2003) Governance Principles for Protected Areas in the 21st Century. A Discussion Paper. Ottawa: Institute on Governance in collaboration with Parks Canada and Canadian International Development Agency.

Hockings, M., Stolton, S., Leverington, F., Dudley, N. and Courrau, J. (2006). Evaluating Effectiveness: A framework for assessing management effectiveness of protected areas. 2nd Edition. Best Practice Protected Area Guidelines Series no. 14. Gland, Switzerland and Cambridge, UK: IUCN. https://doi.org/10.2305/IUCN.CH.2005.PAG.14.en. Accessed on 12 December 2016.

IPSA Institute Sarajevo, Institute for Urbanism of BiH, Eco-Plan Mostar (2012). Spatial Plan of FBiH 2008-2028. Sarajevo, Mostar.

Kaczensky, P., Chapron, G., von Arx, M., Huber, Dj., Andrén, H. and Linnell, J. (eds.) (2012). Status, Management and Distribution of Large Carnivores-Bear, Lynx, Wolf \& Wolverine-In Europe. European Commission. <http://ec.europa.eu/environment/nature/conservation/ species/carnivores/pdf/task_1_part2_species_country_reports.pdf>. Accessed on 5 April 2014.

Kryštufek, B. and Reed, J.M. (2004). Balkan Biodiversity: Pattern and Process in the European Hotspot. Springer

Kus Veenvliet, J. and Sovinc, A. (2009). Protected area management effectiveness in Slovenia. Final report of the RAPPAM analysis. <http:// www.parki.mop.gov.si/Slovenia_RAPPAM_report.pdf>. Accessed on 1 March 2017.

Millennium Ecosystem Assessment (2005). Ecosystems and Human Well-being: Current State and Trends. <http://www.millenniumassessment. org/en/Condition.aspx>. Accessed on 14 March 2014.

Ministria e Mjedisit (2015). Document of Strategic Policies for the Protection of Biodiversity in Albania. Tirana. < https://www.cbd.int/doc/world/ al/al-nbsap-v2-en.pdf>. Accessed on 20 January 2017.

Ministry of Environment and Physical Planning Republic of Macedonia (MEPP) (2004). Biodiversity Strategy and Action Plan of the Republic of Macedonia. Skopje: Ministry of Environment and Physical Planning. https://www.cbd.int/doc/world/mk/mk-nbsap-01-en.pdf $>$. Accessed on 14 March 2014.

Ministry of Environment and Physical Planning Republic of Macedonia (MEPP) (2008). Development of National Emerald Network in the Republic of Macedonia.

Ministry of Environment and Physical Planning Republic of Macedonia (MEPP) (2012). CDDA National Database of Protected Areas. <http:// www.eea.europa.eu/data-and-maps/data/nationally-designated-areas-national-cdda-7>. Accessed on 13 July 2015. 
Ministry of Environment and Physical Planning Republic of Macedonia (MEPP) (2014). Annual Report of Processed Data on Environmental Quality. <http://www.moepp.gov.mk>. Accessed on 13 July 2015.

Ministry of Environment and Physical Planning Republic of Macedonia (MEPP) (2014). Fifth National Report to the Convention on Biological Diversity of the Republic of Macedonia. <https://www.cbd.int/doc/world/mk/mk-nr-05-en.pdf>. Accessed on 14 March 2014.

Ministry of the Environment of Albania (2015). Rrjetiizonavetëmbrojtura - Korrik 2014 -Harta. <http://www.mjedisi.gov.al/al/programi/ biodiversiteti-dhe-zonat-e-mbrojtura/rrjeti-i-zonave-te-mbrojtura>. Accessed on 11 March 2015.

Ministry of the Environment of Albania (2014). Fifth National Report of Albania to the United Nations Convention on Biological Diversity (CBD). GEF Project TF 012599. <https://www.cbd.int/doc/world/al/al-nr-05-en.pdf>. Accessed on 20 March 2016.

Montenegro Ministry of Sustainable Development and Tourism (2014). The Fifth National Report to the United Nations Convention on Biological Diversity. <https://www.cbd.int/doc/world/me/me-nr-05-en.pdf>. Accessed on 20 March 2016.

Montenegro Ministry for Spatial Planning and Environment (2010). National Biodiversity Strategy with the Action Plan for the period $2010-2015$. Draft. <https://www.cbd.int/doc/world/me/me-nbsap-01-en.pdf>. Accessed on 20 March 2016.

Porej, D. and Diku, A. (2009). Final Report - Implementation of the Rapid Assessment and Prioritization of Protected Areas Management Methodology for Assessing Protected Area System in Albania. <http://d2ouvy59p0dg6k.cloudfront.net/downloads/albania_rappam_report. pdf>. Accessed on 11 March 2017.

Porej, D. and Matić, S. (2009). Protected Area Management Effectiveness in Bosnia and Herzegovina. Final report of the RAPPAM analysis. <http://d2ouvy59p0dg6k.cloudfront.net/downloads/bosnia_and_herzegovina_rappam_report.pdf>. Accessed on 11 March 2017.

Porej, D., Piscevic, N., Orlovic-Lovren, V. (2009). Protected Area Management Effectiveness in Serbia. Final report of the RAPPAM analysis. <http://d2ouvy59p0dg6k.cloudfront.net/downloads/serbia_rappam_report.pdf>. Accessed on 11 March 2017.

Porej, D. and Stanišić, N. (2009). Results of the Initial Evaluation of Protected Area Management in Montenegro using RAPPAM Methodology. <http://d2ouvy59p0dg6k.cloudfront.net/downloads/montenegro_rappam_report.pdf>. Accessed on 11 March 2017.

Puzović, S., Sekulić, G., Stojnić, N., Grubač, B., Tucakov, M. (2009). Značajna područja za ptice u Srbiji. Ministarstvo životne sredine i prostornog planiranja, Zavod za zaštitu prirode Srbije, Pokrajinski sekretarijat za zaštitu životne sredine i održivi razvoj.

RAC/SPA (ed.). (2014). Montenegro and Marine Protected Areas: Legal and Institutional framework assessment for conservation of coastal and marine biodiversity and the establishment of MPAs. RAC/SPA and IUCN-Med. Tunis.

Radošević, D. and Todorović, S. (2014). Assessment of the State of Nature Conservation Systems in South-Eastern Europe: Republic of Srpska. Unpublished report.

Republic of Serbia Ministry of Agriculture and Environmental Protection (2014). The Fifth National Report to the United Nations Convention on Biological Diversity. <https://www.cbd.int/doc/world/rs/rs-nr-05-en.pdf>. Accessed on 20 March 2016.

Republic of Serbia Ministry of Agriculture and Environmental Protection (2011). Biodiversity Strategy of the Republic of Serbia for the Period 2011-2018. Belgrade: Ministry of Agriculture and Environmental Protection. <https://www.cbd.int/doc/world/rs/rs-nbsap-01-en.pdf>. Accessed on 20 March 2016.

Republika Slovenija. Ministry of the Environment and Spatial Planning (2002). Biodiversity Conservation Strategy of Slovenia. Ljubljana: Ministry of the Environment and Spatial Planning. < https://www.cbd.int/doc/world/si/si-nbsap-01-en.pdf>. Accessed on 22 December 2016.

Sekulić, G., Tucakov, M., Marinčić, S., Trikić, M. (2014). Assessment of the State of Nature Conservation Systems in South-Eastern Europe: Republic of Serbia. Unpublished report.

Sovinc, A., Fišer Pečnikar, Ž., Gosar, A. (2011). Govorimo isti jezik?: primerjava mednarodnih in slovenskih meril kategorizacije zavarovanih območij. In: Nared, J., Perko, D., Razpotnik Visković, N. Razvoj zavarovanih območij v Sloveniji. Regionalni razvoj 3. Ljubljana: Založba ZRC.

Stanciu, E. and Ionita, A. (2013). Governance of Protected Areas in Eastern Europe-Overview on Different Governance Types, Case Studies, and Lessons Learned. Study commissioned to ProPark, Romania, by the German Federal Agency for Nature Conservation (BfN).

Stolton, S., Hockings, M., Dudley, N., MacKinnon, K., Whitten, T., Leverington, F. (2007). Management Effectiveness Tracking Tool. Reporting Progress at Protected Area Sites. Second edition. Gland, Switzerland: WWF.

The Croatian Parliament (2008). Strategy and Action Plan for the Protection of Biological and Landscape Diversity of the Republic of Croatia.

The Strategy of Bosnia and Herzegovina and Action Plan for Biodiversity and Landscape's Protection (NBSAP BiH 2008-2015). (2008). Draft. <https://www.cbd.int/doc/world/ba/ba-nbsap-01-en.pdf>. Accessed on 13 July 2015.

The World Bank (2010). Sustainable Financing Review for Croatia's Protected Areas. <http://www.min-kulture.hr/userdocsimages/priroda\%20 nova/FINAL\%20Croatia\%20Sus\%20Fin\%20Report\%2031-3-10.pdf>. Accessed on 1 February 2017. 
Thomas, L. and Middleton, J. (2003). Guidelines for Management Planning of Protected Areas. Best Practice Protected Area Guidelines Series No. 10, IUCN Gland, Switzerland and Cambridge, UK. ix + 79 pp. https://doi.org/10.2305/IUCN.CH.2003.PAG.10.en. Accessed on 13 March 2015.

United Nations Development Programme (UNDP) (1997). Capacity Development. Technical Advisory Paper 2. New York: Management Development and Governance Division, UNDP.

United Nations Development Programe/Convention on Biological Diversity (UNEP/CBD COP 10) (2010). COP 10 Decision X.2 Strategic Plan for Biodiversity 2011-2020. Tenth meeting of the Conference of the Parties to the Convention on Biological Diversity, Nagoya, Japan, 18-29 October 2010. <https://www.cbd.int/decision/cop/default.shtml?id=12297>. Accessed on 13 March 2015.

United Nations Environment Programme World Conservation Monitoring Centre (UNEP-WCMC) (2014). Global statistics from the World Database on Protected Areas (WDPA), August 2014. Cambridge, UK: UNEP-WCMC. <http://www.bipindicators.net/pacoverage>. Accessed on 13 March 2015.

Vasilijević, M., Zunckel, K., McKinney, M., Erg, B., Schoon, M., Rosen Michel, T. (2015). Transboundary Conservation: A systematic and integrated approach. Best Practice Protected Area Guidelines Series No. 23, Gland, Switzerland: IUCN. xii + 107 pp. https://doi. org/10.2305/IUCN.CH.2015.PAG.23.en. Accessed on 13 March 2015.

Velagić, A., Radošević, D., Todorović, S. (2014). Assessment of the State of Nature Conservation Systems in South-Eastern Europe: Federation of Bosnia and Herzegovina. Unpublished report.

Zupan, I., Opačić, B., Šestani, G., Gambiroža, P., Plavac, I., Štrbenac, P., Topić, R., Krivanek, G. (2014). Assessment of the State of Nature Conservation Systems in South-Eastern Europe: Republic of Croatia. Unpublished report. 


\section{Annex I: Relevant projects}

\begin{tabular}{|c|c|c|}
\hline Project title & Year & Donor \\
\hline \multicolumn{3}{|l|}{ ALBANIA } \\
\hline $\begin{array}{l}\text { Strengthening national capacity in nature protection - preparation for } \\
\text { Natura } 2000 \text { network }\end{array}$ & 2015 & IPA \\
\hline $\begin{array}{l}\text { Institutional support for the MoEFWA on the conservation and } \\
\text { sustainable use of biodiversity in protected areas }\end{array}$ & 2012-2016 & $\begin{array}{l}\text { Directorate General for Development } \\
\text { Cooperation, Italy }\end{array}$ \\
\hline $\begin{array}{l}\text { Network for the conservation of cetaceans and sea turtles in the Adriatic } \\
\text { (NETCET) }\end{array}$ & 2012-2015 & IPA \\
\hline $\begin{array}{l}\text { Transboundary Biosphere Reserve Prespa: Support for Prespa National } \\
\text { Park-Albania }\end{array}$ & 2010-2015 & KfW Development Bank \\
\hline $\begin{array}{l}\text { Improving coverage for an effective management of coastal and marine } \\
\text { MPAs }\end{array}$ & 2010-2015 & UNDP/GEF \\
\hline Strengthening environmental legislation and enforcement in Albania & 2010 & IPA \\
\hline \multicolumn{3}{|l|}{$\mathrm{BiH}$} \\
\hline $\begin{array}{l}\text { Monitoring of transposition and implementation of the EU environmental } \\
\text { acquis - Phase } 3 \text { (continuation of project RENA) }\end{array}$ & $2014-$ & IPA/European Commission \\
\hline Sustainable forests and landscape management in $\mathrm{BiH}$ & $2014-$ & World Bank \\
\hline The Sava parks network & $2014-$ & EURONATUR \\
\hline $\begin{array}{l}\text { IPA } 2012 \text { - Further strengthening of capacities of phytosanitary sector } \\
\text { in the fields of plant protection products, plant health and seeds and } \\
\text { seedlings, including phytosanitary laboratories and phytosanitary } \\
\text { inspections }\end{array}$ & 2014-2016 & IPA/European Commission \\
\hline Towards strengthened conservation planning in South-Eastern Europe & 2013-2016 & MAVA Foundation \\
\hline $\begin{array}{l}\text { Strengthening environmental institutions in } \mathrm{BiH} \text { and preparation for pre- } \\
\text { accession funds }\end{array}$ & 2013-2014 & EC \\
\hline $\begin{array}{l}\text { IPA } 2009 \text { - Twinning light project Support to laboratory networks of } \\
\text { phytosanitary services }\end{array}$ & 2013-2014 & IPA/European Commission \\
\hline $\begin{array}{l}\text { Support to Bosnia and Herzegovina for Revision of the National } \\
\text { Biodiversity Strategy and Action Plan (NBSAP) and Development of the } \\
\text { Fifth National Report to the Convention on Biological Diversity (UN CBD) }\end{array}$ & 2013-2014 & UNDP/GEF \\
\hline $\begin{array}{l}\text { Support to Bosnia and Herzegovina for Development of National Action } \\
\text { Programmes aligned to the UNCCD 10-Year Strategy and Reporting } \\
\text { Process under UNCCD }\end{array}$ & 2013-2014 & UNDP/GEF \\
\hline Support to implementation of the Birds and Habitats Directives in $\mathrm{BiH}$ & 2012-2014 & $\begin{array}{l}\text { Government of the Kingdom of } \\
\text { Sweden, EU Delegation in } \mathrm{BiH}\end{array}$ \\
\hline WWF Dinaric Arc Parks & 2012-2014 & $\begin{array}{l}\text { Norwegian Ministry of Foreign } \\
\text { Affairs, MAVA Foundation }\end{array}$ \\
\hline National capacity self-assessment (NCSA) of $\mathrm{BIH}$ & 2012-2013 & UNEP \\
\hline $\begin{array}{l}\text { Development of baseline ecological assessments of Una National Park } \\
\text { and Blidinje Nature Park }\end{array}$ & 2012-2013 & GEF/The World Bank \\
\hline Revitalisation of dendroflora of the University campus of Mostar & $2012-2013$ & $\begin{array}{l}\text { Environmental Protection Fund } \\
\text { Federation of } \mathrm{BiH}\end{array}$ \\
\hline $\begin{array}{l}\text { Establishment of primary infrastructure for water supply and wastewater } \\
\text { treatment at Skakavac Natural Monument }\end{array}$ & 2012-2013 & $\begin{array}{l}\text { Federal Ministry of Environment and } \\
\text { Tourism }\end{array}$ \\
\hline Wilderness and the life of wild animals in Una National Park & 2012-2013 & $\begin{array}{l}\text { Environmental Protection Fund } \\
\text { Federation of } \mathrm{BiH}\end{array}$ \\
\hline $\begin{array}{l}\text { Strengthening research capacities and protection of collections of natural } \\
\text { science department }\end{array}$ & 2012-2013 & $\begin{array}{l}\text { Environmental Protection Fund } \\
\text { Federation of } \mathrm{BiH}\end{array}$ \\
\hline
\end{tabular}




\begin{tabular}{|c|c|c|}
\hline Project title & Year & Donor \\
\hline $\begin{array}{l}\text { Reforestation of barren land in the section } 36 b \text { and } 37 c \text { GJ Prača and } \\
\text { the section } 81 b \text { G2.2 - } 47\end{array}$ & 2012-2013 & $\begin{array}{l}\text { Environmental Protection Fund } \\
\text { Federation of } \mathrm{BiH}\end{array}$ \\
\hline $\begin{array}{l}\text { Development of draft measures for remediation of burnt areas of forests } \\
2.2-39\end{array}$ & 2012-2013 & $\begin{array}{l}\text { Environmental Protection Fund } \\
\text { Federation of } \mathrm{BiH}\end{array}$ \\
\hline $\begin{array}{l}\text { Revitalisation of autochthonous plant population on the slopes of the old } \\
\text { town of Blagaj }\end{array}$ & 2012-2013 & $\begin{array}{l}\text { Environmental Protection Fund } \\
\text { Federation of } \mathrm{BiH}\end{array}$ \\
\hline Revitalisation of Bosnian pine in the area of Ruište & 2012-2013 & $\begin{array}{l}\text { Environmental Protection Fund } \\
\text { Federation of } \mathrm{BiH}\end{array}$ \\
\hline $\begin{array}{l}\text { Planting new and revitalising the existing dendroflora on public green } \\
\text { surfaces in Široki Brijeg }\end{array}$ & 2012-2013 & $\begin{array}{l}\text { Environmental Protection Fund } \\
\text { Federation of } \mathrm{BiH}\end{array}$ \\
\hline $\begin{array}{l}\text { Monitoring of forest phytocoenosis of the Skakavac Nature Park and } \\
\text { monitoring of non-forest phytocoenosis of the Vrelo Bosne Nature Park }\end{array}$ & 2012-2013 & Sarajevo Canton \\
\hline $\begin{array}{l}\text { Detection, characterisation and conversation of the new forms of } \\
\text { biodiversity in } \mathrm{BiH} \text { : Case study of the genus SORBUS }\end{array}$ & 2012-2013 & $\begin{array}{l}\text { Environmental Protection Fund } \\
\text { Federation of } \mathrm{BiH}\end{array}$ \\
\hline $\begin{array}{l}\text { Vulnerability assessment of the BiH endemic species (Moltkia petraea) by } \\
\text { application of molecular-genetic markers }\end{array}$ & 2012-2013 & $\begin{array}{l}\text { Environmental Protection Fund } \\
\text { Federation of } \mathrm{BiH}\end{array}$ \\
\hline $\begin{array}{l}\text { Current state and needs for protection of the cave type sites of endemic } \\
\text { stygobiont species in } \mathrm{BiH}\end{array}$ & 2012-2013 & $\begin{array}{l}\text { Environmental Protection Fund } \\
\text { Federation of } \mathrm{BiH}\end{array}$ \\
\hline $\begin{array}{l}\text { Growth limits of the city of Sarajevo and the region by } 2025 \text { - ecological } \\
\text { aspects }\end{array}$ & 2012-2013 & $\begin{array}{l}\text { Environmental Protection Fund } \\
\text { Federation of } \mathrm{BiH}\end{array}$ \\
\hline $\begin{array}{l}\text { Control of the contents of heavy metals in water and fish species in the } \\
\text { Una River } 2-173\end{array}$ & 2012-2013 & $\begin{array}{l}\text { Environmental Protection Fund } \\
\text { Federation of } \mathrm{BiH}\end{array}$ \\
\hline $\begin{array}{l}\text { Identification of sites of importance for protection of threatened species } \\
\text { of Odonata (dragonfly) }\end{array}$ & 2012-2013 & $\begin{array}{l}\text { Environmental Protection Fund } \\
\text { Federation of } \mathrm{BiH}\end{array}$ \\
\hline $\begin{array}{l}\text { Development of inventory methods for assessment of species, structural } \\
\text { and spatial diversity }\end{array}$ & 2012-2013 & $\begin{array}{l}\text { Environmental Protection Fund } \\
\text { Federation of } \mathrm{BiH}\end{array}$ \\
\hline Second International Boračko Jezero biological camp & 2012-2013 & $\begin{array}{l}\text { Environmental Protection Fund } \\
\text { Federation of } \mathrm{BiH}\end{array}$ \\
\hline Printing Newsletter of bird watcher's network in $\mathrm{BiH}$ & 2012-2013 & $\begin{array}{l}\text { Environmental Protection Fund } \\
\text { Federation of } \mathrm{BiH}\end{array}$ \\
\hline $\begin{array}{l}\text { Research and inventorisation of fungi of Igman, Visočica and Bjelašnica } \\
\text { in order to create preliminary list of species of this area }\end{array}$ & 2012-2013 & $\begin{array}{l}\text { Environmental Protection Fund } \\
\text { Federation of } \mathrm{BiH}\end{array}$ \\
\hline $\begin{array}{l}\text { Impact of hydrological regime on mineralisation and possibilities of } \\
\text { remediation }\end{array}$ & 2012-2013 & $\begin{array}{l}\text { Environmental Protection Fund } \\
\text { Federation of } \mathrm{BiH}\end{array}$ \\
\hline Sustainable use and protection of medicinal herbs and fungi resources & 2012 & $\begin{array}{l}\text { Environmental Protection Fund } \\
\text { Federation of } \mathrm{BiH}\end{array}$ \\
\hline $\begin{array}{l}\text { Revitalisation of autochthonous plant population on the slopes of the old } \\
\text { town of Blagaj }\end{array}$ & 2012 & $\begin{array}{l}\text { Environmental Protection Fund } \\
\text { Federation of } \mathrm{BiH}\end{array}$ \\
\hline $\begin{array}{l}\text { Initial assessment of genetic diversity of salmonid fish in order to protect } \\
\text { autochthonous ichthyofauna in the Neretva River and its tributaries }\end{array}$ & 2012 & $\begin{array}{l}\text { Environmental Protection Fund } \\
\text { Federation of } \mathrm{BiH}\end{array}$ \\
\hline $\begin{array}{l}\text { Organisation of meetings to raise awareness on biodiversity and land } \\
\text { degradation }\end{array}$ & 2012 & UNEP \\
\hline $\begin{array}{l}\text { Maintaining the parent stock of the most threatened autochthonous } \\
\text { breeds of domesticated animals in } \mathrm{BiH}\end{array}$ & 2012 & $\begin{array}{l}\text { Environmental Protection Fund } \\
\text { Federation of } \mathrm{BiH}\end{array}$ \\
\hline $\begin{array}{l}\text { Everything you throw in the river today, you will drink from the tap } \\
\text { tomorrow }\end{array}$ & 2012 & $\begin{array}{l}\text { Environmental Protection Fund } \\
\text { Federation of } \mathrm{BiH}\end{array}$ \\
\hline Video and photo-documenting the state of the Neum aquatorium & 2012 & $\begin{array}{l}\text { Environmental Protection Fund } \\
\text { Federation of } \mathrm{BiH}\end{array}$ \\
\hline Yews and Bosnian pine in $\mathrm{BiH}$ & 2012 & $\begin{array}{l}\text { Environmental Protection Fund } \\
\text { Federation of } \mathrm{BiH}\end{array}$ \\
\hline
\end{tabular}




\begin{tabular}{|c|c|c|}
\hline Project title & Year & Donor \\
\hline Raising ecological awareness of members through working activities & 2012 & $\begin{array}{l}\text { Environmental Protection Fund } \\
\text { Federation of } \mathrm{BiH}\end{array}$ \\
\hline $\begin{array}{l}\text { Rehabilitation of area for educational centre in the former Bijambare } \\
\text { mountain lodge }\end{array}$ & 2012 & $\begin{array}{l}\text { Federal Ministry of Environment and } \\
\text { Tourism }\end{array}$ \\
\hline Preservation of natural values through the establishment of monitoring & 2012 & $\begin{array}{l}\text { Federal Ministry of Environment and } \\
\text { Tourism }\end{array}$ \\
\hline Co-financing of equipment purchase for protected areas & 2012 & $\begin{array}{l}\text { Ministry of Spatial Planning and } \\
\text { Environmental Protection of Canton } \\
\text { Sarajevo }\end{array}$ \\
\hline $\begin{array}{l}\text { Strengthening of BiH's environmental institutions and preparation for pre- } \\
\text { accession funds (EnvIS) }\end{array}$ & $2011-2014$ & IPA/European Commission \\
\hline IPA 2008 - Strengthening Administration in BiH for plant health protection & $2011-2013$ & IPA/European Commission \\
\hline Feasibility of geo-information model of hydrographic network & $2011-2012$ & $\begin{array}{l}\text { Environmental Protection Fund } \\
\text { Federation of } \mathrm{BiH}\end{array}$ \\
\hline $\begin{array}{l}\text { Protection of land from water erosion by planting ambient plant species } \\
\text { in the South-Eastern part of the municipality of Mostar }\end{array}$ & $2011-2012$ & $\begin{array}{l}\text { Environmental Protection Fund } \\
\text { Federation of } \mathrm{BiH}\end{array}$ \\
\hline Restauration of exhibition World of wetland and marsh habitats & $2011-2012$ & $\begin{array}{l}\text { Environmental Protection Fund } \\
\text { Federation of } \mathrm{BiH}\end{array}$ \\
\hline Evaluation of Important Bird Areas in the Federation of $\mathrm{BiH}$ & $2011-2012$ & $\begin{array}{l}\text { Environmental Protection Fund } \\
\text { Federation of } \mathrm{BiH}\end{array}$ \\
\hline Land protection and conservation in the area of the Mostar hill Hum & $2011-2012$ & $\begin{array}{l}\text { Environmental Protection Fund } \\
\text { Federation of } \mathrm{BiH}\end{array}$ \\
\hline $\begin{array}{l}\text { Improvement of infrastructure facilities for the Bijambare Protected } \\
\text { Landscape }\end{array}$ & 2011 & $\begin{array}{l}\text { Federal Ministry of Environment and } \\
\text { Tourism }\end{array}$ \\
\hline Acquisition of a tourism train for the Bijambare Protected Landscape & 2011 & $\begin{array}{l}\text { Ministry of Spatial Planning and } \\
\text { Environmental Protection of Canton } \\
\text { Sarajevo, Federal Ministry of } \\
\text { Environment and Tourism }\end{array}$ \\
\hline $\begin{array}{l}\text { Acquisition of equipment for fire protection for the Skakavac Natural } \\
\text { Monument }\end{array}$ & 2011 & Municipality of Centar, Sarajevo \\
\hline Improvement and landscaping of area around the Skakavac waterfall & 2011 & $\begin{array}{l}\text { Sarajevo Economic Region } \\
\text { Development Agency, in cooperation } \\
\text { with the Ministry of Spatial Planning } \\
\text { and the Environmental Protection of } \\
\text { Canton Sarajevo, Cantonal Public } \\
\text { Institution for Protected Nature } \\
\text { Areas, Sarajevo City, Municipality of } \\
\text { Centar and Novi Grad, Sarajevo }\end{array}$ \\
\hline Landscaping of area for the Vrelo Bosne Natural Monument & 2011 & $\begin{array}{l}\text { Federal Ministry of Environment and } \\
\text { Tourism }\end{array}$ \\
\hline $\begin{array}{l}\text { Acquisition of containers for accomodation of Roma families (Vrelo Bosne } \\
\text { Natural Monument) }\end{array}$ & 2011 & $\begin{array}{l}\text { Federal Ministry of Environment and } \\
\text { Tourism }\end{array}$ \\
\hline $\begin{array}{l}\text { Development of training programme and materials for training on } \\
\text { international environmental obligations of } \mathrm{BiH}\end{array}$ & 2011 & $\mathrm{CRI} \mathrm{BIH}$ \\
\hline Development of small scale commercial agriculture & 2010-2014 & $\begin{array}{l}\text { International Development } \\
\text { Association and the Government of } \\
\text { the Republic of Srpska }\end{array}$ \\
\hline The Neretva and Trebišnjica management project & 2010-2014 & $\begin{array}{l}\text { GEF, Municipalities of Ljubuški and } \\
\text { Konjic, Environmental Protection } \\
\text { Fund Federation of BiH, IPA }\end{array}$ \\
\hline
\end{tabular}




\begin{tabular}{|c|c|c|}
\hline Project title & Year & Donor \\
\hline $\begin{array}{l}\text { MDG - F programme preserving the environment and climate change } \\
\text { titled "The standardisation of environmental management: linking local } \\
\text { and national activities in BiH" }\end{array}$ & 2010-2013 & $\begin{array}{l}\text { The Millennium Development Goals } \\
\text { Fund }\end{array}$ \\
\hline $\begin{array}{l}\text { Enabling activities for the preparation of the BiH's Second National } \\
\text { Communication (SNC) under the UN Convention on Climate Change }\end{array}$ & 2010-2013 & UNDP/GEF \\
\hline $\begin{array}{l}\text { Valorisation of natural values of virgin forest area of Gornja Trstionica } \\
\text { Bukovica - Municipality of Kakanj }\end{array}$ & 2010-2013 & Municipality of Kakanj \\
\hline $\begin{array}{l}\text { Study for identification of activities, programmes and resources for } \\
\text { improving the water quality in the rivers: Miljacka, Željeznica, Zujevina, } \\
\text { Kasindolski potok and part of the river Bosna }\end{array}$ & 2010-2012 & $\begin{array}{l}\text { Sarajevo Economic Region } \\
\text { Development Agency }\end{array}$ \\
\hline $\begin{array}{l}\text { Project of forest and mountain protected areas: preparation of the } \\
\text { management plans for Una National Park and feasibility studies for the } \\
\text { Prenj - Čvrsnica - Čabulja - Vran Protected Area }\end{array}$ & 2010-2011 & GEF/The World Bank \\
\hline $\begin{array}{l}\text { Preparation of publications and relevant materials for combating the } \\
\text { invasive species in } \mathrm{BiH} \text { : Amorpha (Amorpha fructicosa), an invasive } \\
\text { species in } \mathrm{BiH}\end{array}$ & 2010 & $\begin{array}{l}\text { Federal Ministry of Environment and } \\
\text { Tourism }\end{array}$ \\
\hline Forest and mountain protected areas & 2009-2013 & $\begin{array}{l}\text { GEF/The World Bank, Government } \\
\text { of the Republic of Srpska }\end{array}$ \\
\hline Regional Environmental Network for Accession (RENA) & 2009-2013 & IPA/European Commission \\
\hline The Spreča River Basin Initiative - Clear minds for clear water & 2009-2011 & European Commission \\
\hline \multicolumn{3}{|l|}{ CROATIA } \\
\hline PARKS Strengthening the National Protected Area System & 2014-2018 & UNDP/GEF \\
\hline $\begin{array}{l}\text { WWF Sustainable economic activities in Mediterranean Marine } \\
\text { Protected Areas-SEA Med project }\end{array}$ & 2013-2016 & \\
\hline $\begin{array}{l}\text { Capacity building plans for efficient protected area management in } \\
\text { Eastern Europe }\end{array}$ & 2013-2015 & BfN/ProPark \\
\hline $\begin{array}{l}\text { Adriatic Network for the conservation of cetaceans and sea turtles in the } \\
\text { Adriatic (NETCET) }\end{array}$ & 2012-2015 & IPA \\
\hline $\begin{array}{l}\text { Anchoring the Danube River network of protected areas as platform for } \\
\text { preservation of Danube natural heritage }\end{array}$ & 2012-2014 & SEE IPA-EU \\
\hline $\begin{array}{l}\text { Development of habitat types database (CRO Habitats) as a part of the } \\
\text { Nature Protection Information System (NPIS) }\end{array}$ & 2012-2014 & IPA 2008 FF RAC \\
\hline $\begin{array}{l}\text { National biodiversity planning to support the implementation of the CBD } \\
2011 \text { - } 2020 \text { Strategic Plan in Croatia }\end{array}$ & 2012-2014 & GEF Trust Fund \\
\hline $\begin{array}{l}\text { Supporting CSOs in development of partnerships for sustainable use of } \\
\text { protected areas in Croatia, including potential Natura } 2000 \text { sites }\end{array}$ & 2012-2014 & IPA 2011 \\
\hline $\begin{array}{l}\text { Sustainable integrated management of international river corridors in SEE } \\
\text { countries-SEE RIVER }\end{array}$ & 2012-2014 & IPA SEE \\
\hline WWF Dinaric Arc Parks & 2012-2014 & $\begin{array}{l}\text { MAVA Foundation, Ministry of } \\
\text { Foreign Affairs of the Kingdom of } \\
\text { Norway }\end{array}$ \\
\hline Living Danube & 2012-2014 & $\begin{array}{l}\text { IPA Cross-Border Programme } \\
\text { Croatia-Serbia }\end{array}$ \\
\hline Promoting eco-tourism in the Sava River basin & 2012-2013 & USA Embassy in Croatia \\
\hline EU Natura 2000 Integration Project (NIP) & $2011-2016$ & The World Bank Loan \\
\hline $\begin{array}{l}\text { European Life Line: Future Transboundary Biosphere Reserve Mura } \\
\text { Drava Danube }\end{array}$ & 2011-2013 & MAVA Foundation, Asamer \\
\hline $\begin{array}{l}\text { Capacity building of county public institutions with aim of preparation } \\
\text { of management plans (MeP) and strengthening of the nature protection } \\
\text { inspection for proposed Natura } 2000 \text { sites (Natura MANMON) }\end{array}$ & $2011-2013$ & IPA 2009, Twinning Light \\
\hline
\end{tabular}




\begin{tabular}{|c|c|c|}
\hline Project title & Year & Donor \\
\hline $\begin{array}{l}\text { IPA Development of faunistic and speleological databases (CRO Fauna } \\
\text { and CRO Speleo), as part of NPIS (Nature Protection Information System } \\
\text { (NPIS) }\end{array}$ & 2011-2012 & IPA TAIB 2007 \\
\hline $\begin{array}{l}\text { Restoration of wetland habitats in the Mura, Drava and Danube River } \\
\text { basins }\end{array}$ & 2011-2012 & The Coca-Cola Company \\
\hline Transboundary conservation of the Central Danube region & 2011-2012 & $\begin{array}{l}\text { IPA Hungary-Croatia Cross-border } \\
\text { Co-operation Programme }\end{array}$ \\
\hline $\begin{array}{l}\text { Capacity building for hydro-morphology measures and monitoring in } \\
\text { Croatia (MEANDER) }\end{array}$ & $2011-2012$ & $\begin{array}{l}\text { NL EVD, Agency for International } \\
\text { Business and Co-operation Unit for } \\
\text { International Public Co-operation, } \\
\text { Ministry of Infrastructure and the } \\
\text { Environment of Netherlands }\end{array}$ \\
\hline Bilingual environmental education through the Drava River basin & 2010-2011 & $\begin{array}{l}\text { IPA Hungary-Croatia Cross-border } \\
\text { Co-operation Programme }\end{array}$ \\
\hline $\begin{array}{l}\text { COASTANCE - Regional Common Action Strategy against Coastal } \\
\text { Erosion and climate change effects for a sustainable coastal planning in } \\
\text { the Mediterranean basin }\end{array}$ & 2010-2011 & $\begin{array}{l}\text { European Regional Development } \\
\text { Fund }\end{array}$ \\
\hline $\begin{array}{l}\text { IPA Identification and setting-up of the marine part of Natura } 2000 \\
\text { network in Croatia - marine Natura } 2000\end{array}$ & 2010-2011 & IPA TAIB 2007 \\
\hline $\begin{array}{l}\text { Wings across the Balkans: Preparing countries in the Western Balkans } \\
\text { for implementing the EU Wild Birds Directive }\end{array}$ & 2010-2011 & $\begin{array}{l}\text { European Commission, } \\
\text { Environmental Protection and } \\
\text { Energy Efficiency Fund, Government } \\
\text { Office for Cooperation with NGOs }\end{array}$ \\
\hline $\begin{array}{l}\text { Sustaining rural communities and their traditional landscapes through } \\
\text { strengthened environmental governance in trans boundary protected } \\
\text { areas of the Dinaric Arc }\end{array}$ & 2009-2012 & Ministry of Foreign Affairs of Finland \\
\hline $\begin{array}{l}\text { Strategic partnership for the Mediterranean Sea large marine ecosystem: } \\
\text { regional component - Pilot project Croatia MedPAN South }\end{array}$ & 2009-2012 & $\begin{array}{l}\text { European Commission, EuropeAid, } \\
\text { The French Facility for Global } \\
\text { Environment, MAVA Foundation }\end{array}$ \\
\hline Sources of life & 2009-2012 & $\begin{array}{l}\text { Operational Programme IPA } \\
\text { Slovenia-Croatia 2007-2013 }\end{array}$ \\
\hline From Orchards to Juice & 2009-2012 & $\begin{array}{l}\text { Operational Programme IPA } \\
\text { Slovenia-Croatia 2007-2013 }\end{array}$ \\
\hline $\begin{array}{l}\text { Long-term management of orchards for their nature conservation, } \\
\text { economical and developmental function in protected areas }\end{array}$ & 2009-2012 & $\begin{array}{l}\text { Operational Programme IPA } \\
\text { Slovenia-Croatia 2007-2013 }\end{array}$ \\
\hline $\begin{array}{l}\text { Strengthening eco-tourism capacity in areas of exceptional nature value } \\
\text { in Western Balkan countries }\end{array}$ & 2009-2011 & $\begin{array}{l}\text { European Commission, The UN } \\
\text { Refugee Agency, Government Office } \\
\text { for Cooperation with NGOs, Plaški } \\
\text { County, COOR }\end{array}$ \\
\hline $\begin{array}{l}\text { Habitat restoration and tourism development using natural grazing in the } \\
\text { Kopački Rit Nature Park }\end{array}$ & 2009-2010 & $\begin{array}{l}\text { The Dutch Ministry of Agriculture, } \\
\text { Nature and Food Quality's } \\
\text { programme BBI MATRA }\end{array}$ \\
\hline $\begin{array}{l}\text { Managing natural assets and protected areas as sustainable regional } \\
\text { development opportunities (NATREG) }\end{array}$ & 2009-2010 & $\begin{array}{l}\text { European Regional Development } \\
\text { Fund for the Transnational } \\
\text { Programme of South-Eastern } \\
\text { Europe }\end{array}$ \\
\hline Natura 2000 marine areas in Split-Dalmatia County & 2009-2010 & $\begin{array}{l}\text { The Dutch Ministry of Agriculture, } \\
\text { Nature and Food Quality's } \\
\text { programme KNIP MATRA }\end{array}$ \\
\hline $\begin{array}{l}\text { WB Project preparation services for the Nature Protection Investment } \\
\text { Project (NPIP project) }\end{array}$ & 2009-2010 & $\begin{array}{l}\text { International Bank for } \\
\text { Reconstruction and Development }\end{array}$ \\
\hline
\end{tabular}




\begin{tabular}{|c|c|c|}
\hline Project title & Year & Donor \\
\hline Kornati archipelago 2009 biodiversity research & 2009 & $\begin{array}{l}\text { Embassy of Switzerland in Zagreb, } \\
\text { Ministry of Foreign Affairs of the } \\
\text { Kingdom of Netherlands, WWF } \\
\text { Netherlands, Embassy of Norway, } \\
\text { Embassy of Finland }\end{array}$ \\
\hline $\begin{array}{l}\text { Institutional strengthening and implementation of the Natura } 2000 \\
\text { ecological network in Croatia }\end{array}$ & 2008-2009 & $\begin{array}{l}\text { EU Pre-accession assistance } \\
\text { programme PHARE } 2005\end{array}$ \\
\hline Biodiversity of underground fauna in Karlovac County & 2008-2009 & $\begin{array}{l}\text { EU Pre-accession assistance } \\
\text { programme PHARE } 2006\end{array}$ \\
\hline $\begin{array}{l}\text { Conservation of the Long-fingered bat, Myotis capaccinii, for } \\
\text { conservation of the karst habitat in Croatia }\end{array}$ & 2008-2009 & Whitley Fund \\
\hline Democracy in practice & 2008-2009 & $\begin{array}{l}\text { EU Pre-accession assistance } \\
\text { programme PHARE } 2006\end{array}$ \\
\hline Strengthening NGOs capability for Natura 2000 activities implementation & 2008-2009 & $\begin{array}{l}\text { EU Pre-accession assistance } \\
\text { programme PHARE } 2006\end{array}$ \\
\hline Strengthening local capacity for Natura 2000 and nature conservation & 2008-2009 & $\begin{array}{l}\text { EU Pre-accession assistance } \\
\text { programme PHARE } 2006\end{array}$ \\
\hline $\begin{array}{l}\text { Promoting sustainable management of natural resources through } \\
\text { education and raising public awareness }\end{array}$ & 2008-2009 & $\begin{array}{l}\text { EU Pre-accession assistance } \\
\text { programme PHARE } 2006\end{array}$ \\
\hline $\begin{array}{l}\text { Development of Eco sustainable programme for tourism facilities in } \\
\text { Croatia }\end{array}$ & 2008-2009 & $\begin{array}{l}\text { EU Pre-accession assistance } \\
\text { programme PHARE } 2006\end{array}$ \\
\hline $\begin{array}{l}\text { Capacity building of local public institutions for management of protected } \\
\text { natural values, in process of legislative alignment with EU }\end{array}$ & 2008 & SIFA \\
\hline $\begin{array}{l}\text { UNDP Conservation and sustainable use of biodiversity in the Dalmatian } \\
\text { coast through greening coastal development (COAST) }\end{array}$ & $2007-2012$ & GEF \\
\hline Dinaric Arc ecoregion 2012 Protected Areas Programme & $2007-2011$ & WWF \\
\hline Sustainable island and coastal development in Šibenik-Knin County & $2007-2009$ & $\begin{array}{l}\text { MATRA Social Transformation } \\
\text { Programme, Ministry of Foreign } \\
\text { Affairs of the Kingdom of } \\
\text { Netherlands, Public Institution } \\
\text { of Kornati National Park, local } \\
\text { government }\end{array}$ \\
\hline Neretva River Delta Forum for sustainable use of natural resources & 2007-2009 & $\begin{array}{l}\text { Embassy of Switzerland-Swiss } \\
\text { Cooperation Office }\end{array}$ \\
\hline Development of the ecological network along the Sava River & 2007-2009 & $\begin{array}{l}\text { European Commission LIFE III, } \\
\text { Swiss Agency for Development and } \\
\text { Cooperation }\end{array}$ \\
\hline $\begin{array}{l}\text { Capacity building for adjustment of Croatian agricultural practice with EU } \\
\text { environmental and nature protection legislation }\end{array}$ & 2007-2009 & EU CARDS 2004 \\
\hline Development of cross border tourism in Central Danube region & $2007-2009$ & EU CARDS 2004 \\
\hline Ecological network knowledge & $2007-2009$ & $\begin{array}{l}\text { Ministry of Agriculture of the } \\
\text { Kingdom of Netherlands }\end{array}$ \\
\hline $\begin{array}{l}\text { INTERREG IIIB CADSES-GREEN BELT: Protection and evaluation of } \\
\text { natural heritage along the former Iron Curtain }\end{array}$ & 2006-2009 & EU CARDS programme \\
\hline Protected Area Management System in Croatia (PAMS) & 2006-2009 & $\begin{array}{l}\text { Government of the Kingdom of } \\
\text { Norway, Environmental Protection } \\
\text { and Energy Efficiency Fund }\end{array}$ \\
\hline
\end{tabular}




\begin{tabular}{|c|c|c|}
\hline Project title & Year & Donor \\
\hline \multicolumn{3}{|l|}{ MACEDONIA } \\
\hline $\begin{array}{l}\text { IPA TAIB } 2011 \text { Strengthening the capacities for implementation of Natura } \\
2000\end{array}$ & 2016-2017 & EU \\
\hline $\begin{array}{l}\text { Support to the Republic of Macedonia for revision of the National } \\
\text { Strategy for Biological Diversity with Action Plan and development of the } \\
\text { Fifth National Report to the Convention on Biological Diversity }\end{array}$ & 2013-2014 & UNEP/GEF \\
\hline Programme for conservation of nature in Macedonia & 2012-2016 & Swiss Government \\
\hline Plan for Bregalnica watershed management & 2012-2016 & Swiss Government \\
\hline $\begin{array}{l}\text { Conservation and sustainable use of biodiversity at Lakes Prespa, Ohrid } \\
\text { and Shkodra/Skadar }\end{array}$ & 2012-2017 & $\begin{array}{l}\text { German Federal Ministry for } \\
\text { Economic Cooperation and } \\
\text { Development }\end{array}$ \\
\hline WWF Dinaric Arc Parks & 2012-2014 & $\begin{array}{l}\text { MAVA Foundation, Ministry of } \\
\text { Foreign Affairs of the Kingdom of } \\
\text { Norway }\end{array}$ \\
\hline $\begin{array}{l}\text { Support for the implementation of National Biosafety Framework for the } \\
\text { Republic }\end{array}$ & 2011-2014 & UNEP/GEF \\
\hline Rehabilitation of Prespa Lake ecosystems & $2010-2015$ & $\begin{array}{l}\text { Swiss Agency for Development and } \\
\text { Cooperation }\end{array}$ \\
\hline Integrated ecosystem management in the Prespa Basin & 2008-2012 & UNEP/GEF \\
\hline $\begin{array}{l}\text { Strengthening the ecological, institutional and financial sustainability of } \\
\text { Macedonia's protected area system }\end{array}$ & 2008-2011 & UNDP/GEF \\
\hline $\begin{array}{l}\text { Environmental protection, economic development and promotion of } \\
\text { sustainable eco-tourism in Mavrovo National Park }\end{array}$ & 2008-2011 & \\
\hline Development of a national ecological network MAK-NEN & $2008-2011$ & $\begin{array}{l}\text { Dutch Ministry of Agriculture, Nature } \\
\text { and Food Safety (BBI MATRA) }\end{array}$ \\
\hline $\begin{array}{l}\text { Transboundary Biosphere Reserve Prespa Park-Support to Galičica } \\
\text { National Park }\end{array}$ & $2008-2011$ & KfW Development Bank \\
\hline Development of the Emerald Network in the Republic of Macedonia & 2002-2008 & \\
\hline \multicolumn{3}{|l|}{ MONTENEGRO } \\
\hline Strengthening of the environmental protection system in Montenegro & 2015-2018 & IPA \\
\hline Environment and Climate Regional Accession Network (ECRAN) & 2013-2016 & RENA \\
\hline $\begin{array}{l}\text { National Biodiversity Planning to Support the implementation of the CBD } \\
\text { 2011-2020 Strategic Plan in Montenegro }\end{array}$ & 2012-2015 & GEF/UNDP \\
\hline $\begin{array}{l}\text { Conservation and sustainable use of biodiversity at Lakes Prespa, Ohrid } \\
\text { and Shkoder }\end{array}$ & $2012-2014$ & GIZ/German Government \\
\hline $\begin{array}{l}\text { IPA twinning project Support to environmental management in } \\
\text { Montenegro }\end{array}$ & 2010-2013 & $\begin{array}{l}\text { Italian Ministry of the Environment, } \\
\text { Land and Sea }\end{array}$ \\
\hline $\begin{array}{l}\text { Strengthening the financial sustainability of protected areas in } \\
\text { Montenegro }\end{array}$ & $2009-2014$ & GEF/UNDP \\
\hline $\begin{array}{l}\text { Strengthening the sustainability of the protected area system of } \\
\text { Montenegro }\end{array}$ & $2009-2014$ & GEF/UNDP \\
\hline $\begin{array}{l}\text { Montenegro and Natura 2000: Strengthening the capacity of government } \\
\text { and civil sector to adapt to the EU Nature Protection Acquis }\end{array}$ & 2009-2012 & Norwegian Government \\
\hline \multicolumn{3}{|l|}{ SERBIA } \\
\hline ECRAN project & 2013-2016 & EU \\
\hline $\begin{array}{l}\text { National biodiversity planning to support the implementation of the CBD } \\
2011-2020 \text { Strategic Plan in the Republic of Serbia }\end{array}$ & $2013-2016$ & UNDP/GEF \\
\hline $\begin{array}{l}\text { 'NatuRegio Balkans' Transnational cooperation for sustainable nature } \\
\text { conservation-selected Balkan states on their way to Europe }\end{array}$ & 2013-2015 & \\
\hline
\end{tabular}




\begin{tabular}{|c|c|c|}
\hline Project title & Year & Donor \\
\hline WWF Dinaric Arc Parks & 2012-2014 & $\begin{array}{l}\text { Norwegian Ministry of Foreign } \\
\text { Affairs, MAVA Foundation }\end{array}$ \\
\hline $\begin{array}{l}\text { 'BioREGIO Carpathians' Integrated management of biological and } \\
\text { landscape diversity for sustainable regional development and ecological } \\
\text { connectivity in the Carpathians }\end{array}$ & $2011-2013$ & \\
\hline Ensuring financial sustainability of the protected area system of Serbia & 2010-2014 & UNDP/GEF \\
\hline $\begin{array}{l}\text { IPA } 2007 \text { twinning project Strengthening Administrative Capacities for } \\
\text { Protected Areas in Serbia (Natura 2000) }\end{array}$ & 2010-2012 & \\
\hline $\begin{array}{l}\text { Establishing the Emerald Network in Serbia, within implementation of the } \\
\text { Bern Convention }\end{array}$ & 2005-2011 & Council of Europe \\
\hline \multicolumn{3}{|l|}{ SLOVENIA } \\
\hline $\begin{array}{l}\text { Natura } 2000 \text { management programme for Slovenia for the period } \\
\text { 2014-2020 }\end{array}$ & 2012-2015 & EU LIFE \\
\hline Sustainable management of Alpine pastures in protected area & 2012-2014 & $\begin{array}{l}\text { European Territorial Cooperation, } \\
\text { Cross-Border Cooperation Slovenia- } \\
\text { Austria }\end{array}$ \\
\hline $\begin{array}{l}\text { SEE RIVER-Sustainable integrated management of international river } \\
\text { corridors in SEE countries }\end{array}$ & 2012-2014 & $\begin{array}{l}\text { European Territorial Cooperation, } \\
\text { Transnational Cooperation, SEE }\end{array}$ \\
\hline $\begin{array}{l}\text { WETMAN-Conservation and management of freshwater wetlands in } \\
\text { Slovenia }\end{array}$ & $2011-2015$ & EU LIFE \\
\hline Apis mellifera carnica bioindicator and promoter of biodiversity & 2010-2014 & $\begin{array}{l}\text { European Territorial Cooperation, } \\
\text { Cross-Border Cooperation Slovenia- } \\
\text { Austria }\end{array}$ \\
\hline $\begin{array}{l}\text { MEDPAN North, Network of marine protected area managers in the } \\
\text { Mediterranean }\end{array}$ & 2010-2013 & $\begin{array}{l}\text { European Territorial Cooperation, } \\
\text { Transnational Cooperation, } \\
\text { Mediterranean }\end{array}$ \\
\hline $\begin{array}{l}\text { NATREG - Managing natural assets and protected areas as sustainable } \\
\text { regional development opportunities }\end{array}$ & 2009-2011 & $\begin{array}{l}\text { European Territorial Cooperation, } \\
\text { Transnational Cooperation, SEE }\end{array}$ \\
\hline Natura 2000 in Slovenia-Management models and information system & $2005-2007$ & EU LIFE \\
\hline
\end{tabular}







\section{IUCN}

INTERNATIONAL UNION

FOR CONSERVATION OF NATURE

REGIONAL OFFICE FOR EASTERN

EUROPE AND CENTRAL ASIA (ECARO)

Dr Ivana Ribara 91

11070 Belgrade, Serbia

ecaro@iucn.org

Tel +381112272411

Fax +38111227253

www.iucn.org/ecaro

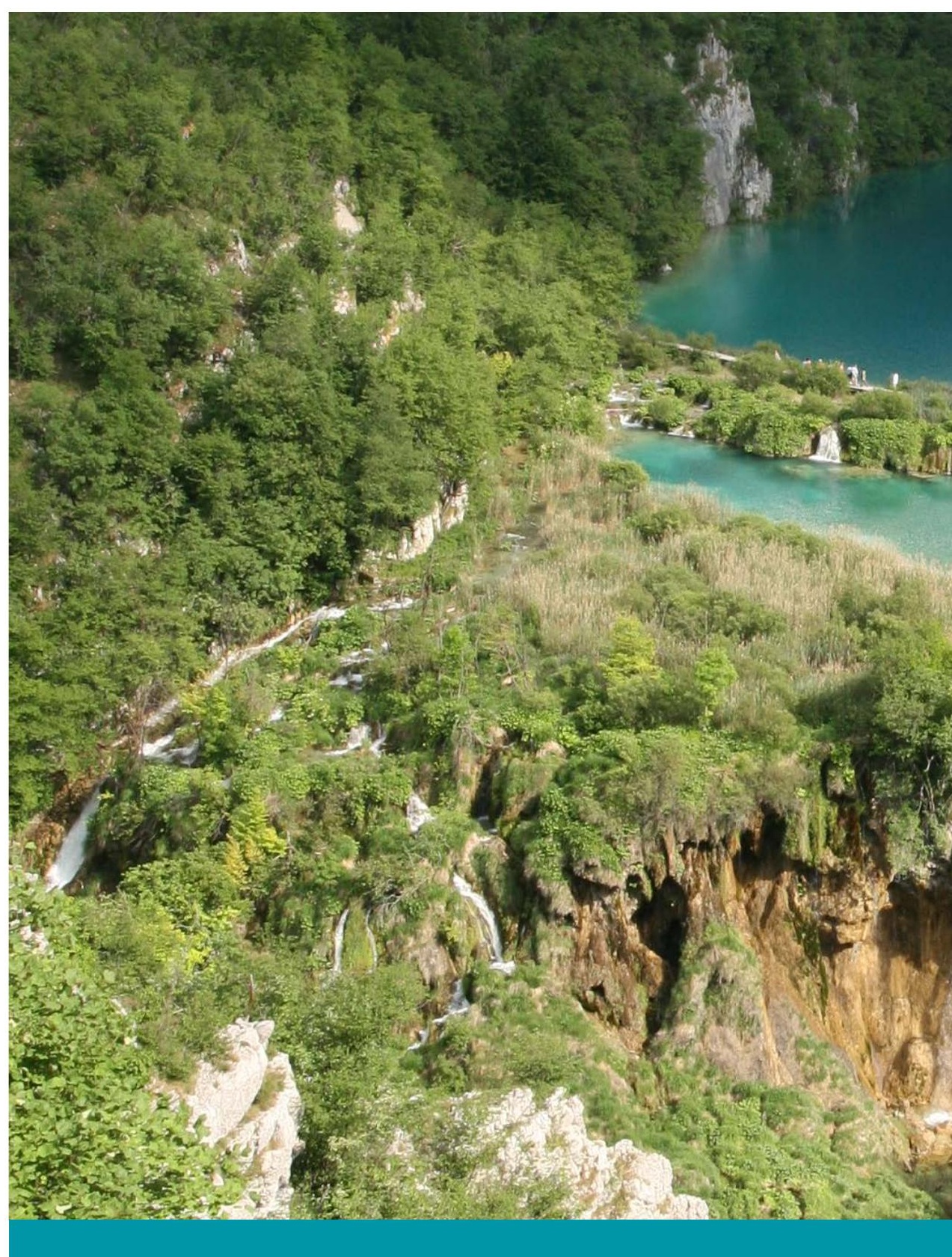

